\title{
Assessment of application, effectiveness, and compliance of forestry best management practices in West Virginia
}

\author{
William A. Goff \\ West Virginia University
}

Follow this and additional works at: https://researchrepository.wvu.edu/etd

\section{Recommended Citation}

Goff, William A., "Assessment of application, effectiveness, and compliance of forestry best management practices in West Virginia" (2005). Graduate Theses, Dissertations, and Problem Reports. 1666.

https://researchrepository.wvu.edu/etd/1666

This Thesis is protected by copyright and/or related rights. It has been brought to you by the The Research Repository @ WVU with permission from the rights-holder(s). You are free to use this Thesis in any way that is permitted by the copyright and related rights legislation that applies to your use. For other uses you must obtain permission from the rights-holder(s) directly, unless additional rights are indicated by a Creative Commons license in the record and/ or on the work itself. This Thesis has been accepted for inclusion in WVU Graduate Theses, Dissertations, and Problem Reports collection by an authorized administrator of The Research Repository @ WVU. For more information, please contact researchrepository@mail.wvu.edu. 
ASSESSMENT OF APPLICATION, EFFECTIVENESS, AND COMPLIANCE OF FORESTRY BEST MANAGEMENT PRACTICES IN WEST VIRGINIA

\author{
William A. Goff
}

Thesis submitted to the Davis College of Agriculture, Forestry, and Consumer Sciences at West Virginia University

in partial fulfillment of the requirements

for the degree of

\author{
Master of Science \\ in \\ Forestry
}

Approved by

Dr. Jingxin Wang, Committee Chairperson

Dr. Darrell R. Dean

Dr. Joseph McNeel

Mr. Steve Milauskas

Division of Forestry

Morgantown, West Virginia

2005

Keywords: Best Management Practices, Compliance Assessment, Water Quality, Timber Harvesting, Forest Operations, Forest Management 


\section{ABSTRACT \\ ASSESSMENT OF APPLICATION, EFFECTIVENESS, AND COMPLIANCE OF FORESTRY BEST MANAGEMENT PRACTICES IN WEST VIRGINIA}

\section{By William A. Goff}

The application, effectiveness, and compliance of forestry best management practices (BMPs) were assessed based on 116 randomly selected sites harvested between November 2003 and March 2004 in West Virginia. Landowners were contacted to gain permission for site visits according to the random list. The landowners were also asked a series of questions to identify their knowledge and satisfaction about the harvest and BMPs. A series of eight checklists were used to assess 26 BMPs on haul roads, skid trails, landings, and in streamside management zones (SMZs). Thirty three out of 116 sites with SMZs were further evaluated for BMP applications and effectiveness. Spatial data, soil, and stream type were also collected from the site to identify how these spatial attributes affect BMP application, effectiveness, and compliance. Data collected were also analyzed statistically to examine the differences of BMP application, effectiveness, and compliance among forester involvement, ownership type, and Forest Districts. Results indicated that compliance on haul roads was $80 \%$, skid trails $(70 \%)$, landings (78\%), and SMZs (61\%). Statewide compliance generally increased from the previous study to $72 \%$. 


\section{ACKNOWLEDGEMENTS}

I would like to thank my parents for supporting me throughout this experience. They continuously support me and never allow me to give up. I would also like to thank Dr. Wang for all of his help and patience over the past two years. Special thanks to members of my committee: Dr. McNeel, Dr. Dean, and Mr. Milauskas for their support and encouragement during this project. I must also thank Greg Hamons and Mark Rexrode for their help during the field work for this project. 


\section{TABLE OF CONTENTS}

ACKNOWLEDGEMENTS ........................................................................................................

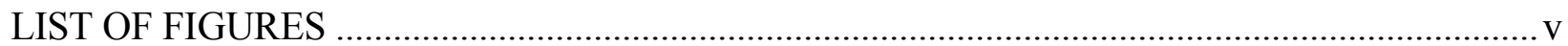

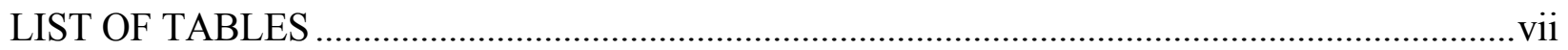

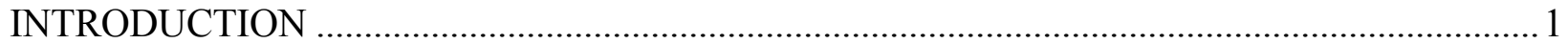

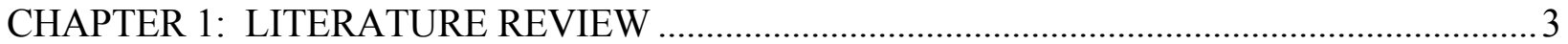

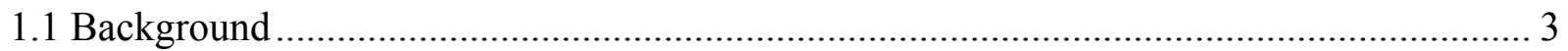

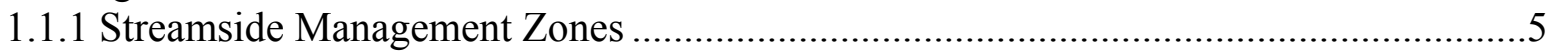

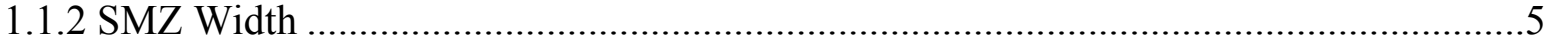

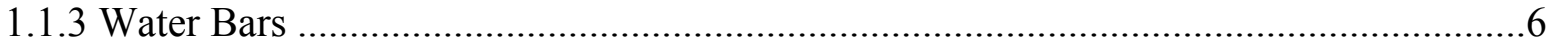

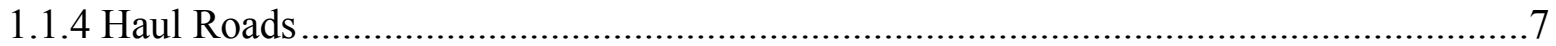

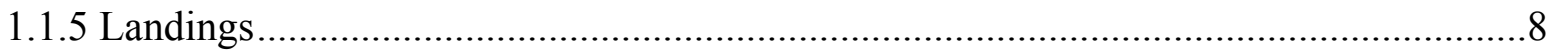

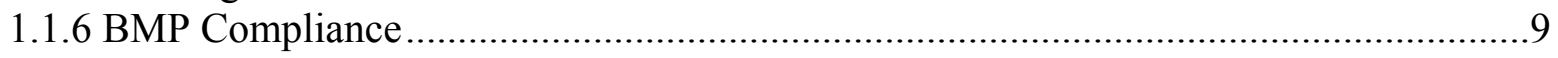

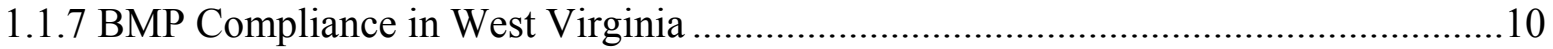

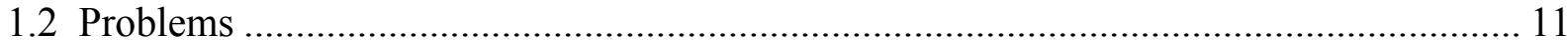

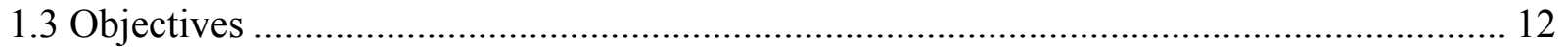

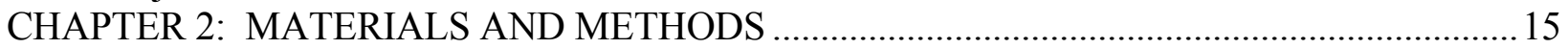

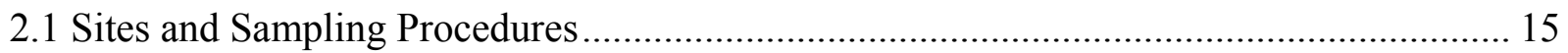

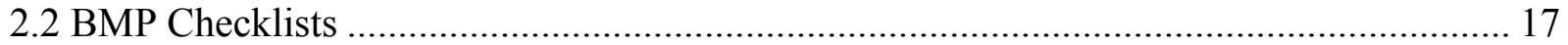

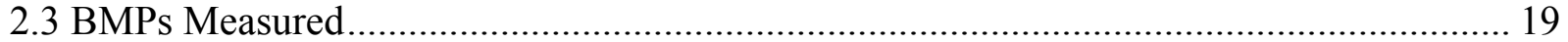

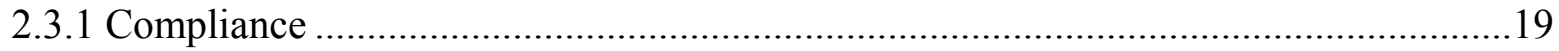

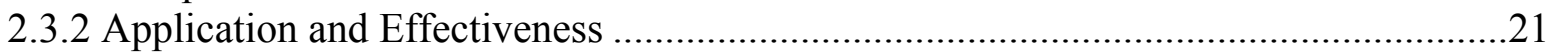

2.4 Data Collection and Analysis................................................................................. 24

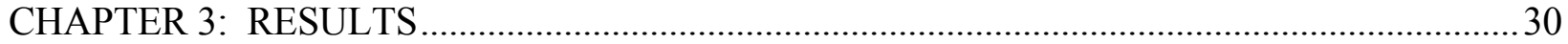

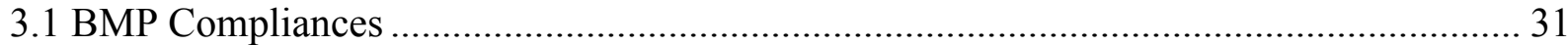

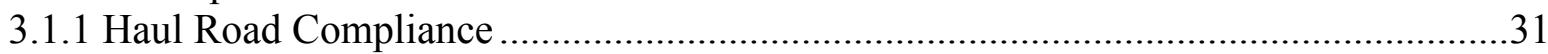

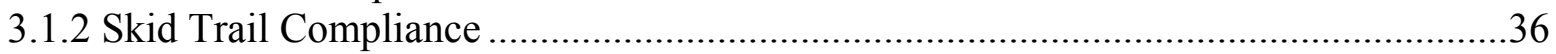

3.1.3 Landing Compliance ..........................................................................................4

3.1.4 Streamside Management Zone Compliance ……...................................................44

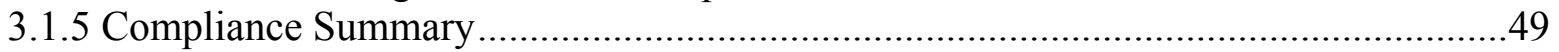

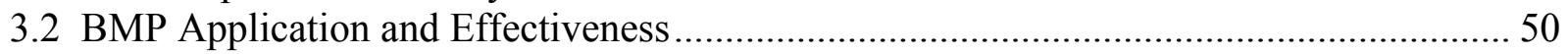

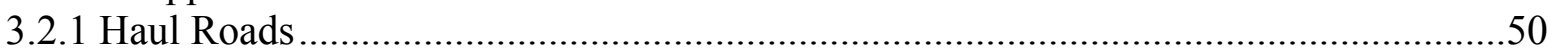

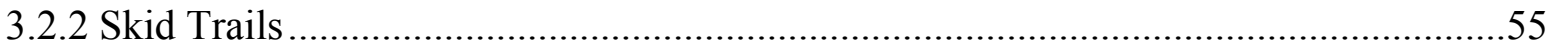

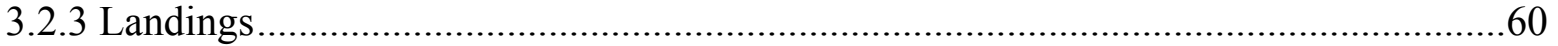

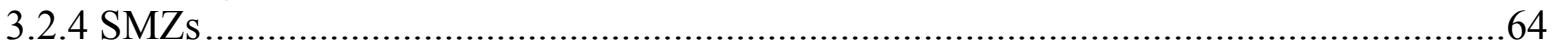

3.3 Responses of Landowners to BMPs and Harvests....................................................... 70

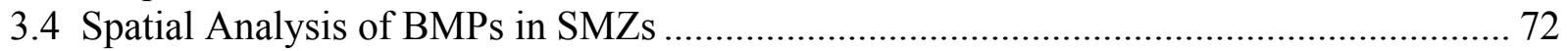

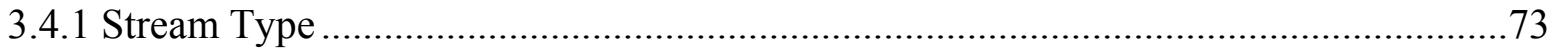

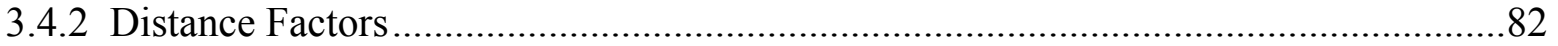

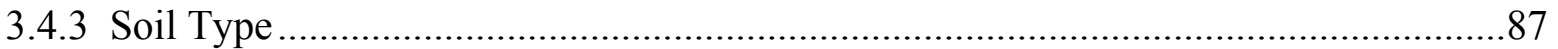

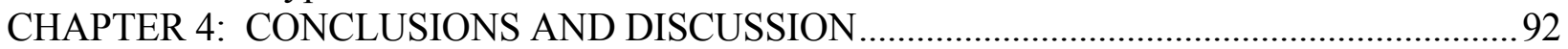

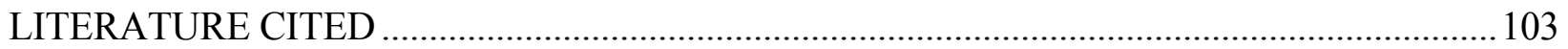

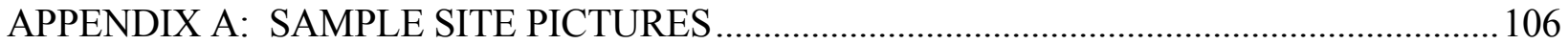




\section{LIST OF FIGURES}

Figure 2.1. Site distribution by county for BMP assessments. ................................................. 16

Figure 2.2. Flow Chart of BMP Assessment Process.............................................................. 23

Figure 3.1. Haul road application and effectiveness ranking percentage by ownership............... 55

Figure 3.2. Skid trail application and effectiveness ranking percentage by ownership................ 60

Figure 3.3. BMP application and effectiveness ranking percentage on landings by ownership. . 64

Figure 3.4. BMP application and effectiveness ranking percentage in SMZs by ownership....... 68

Figure 3.5. Application and Effectiveness rankings shown as percentages. ............................... 69

Figure 3.6. Poor application on perennial stream. …….......................................................... 74

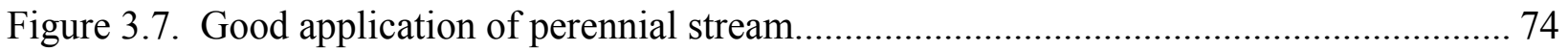

Figure 3.8. Good application of intermittent stream................................................................ 76

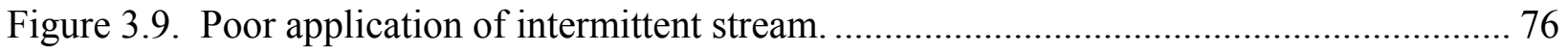

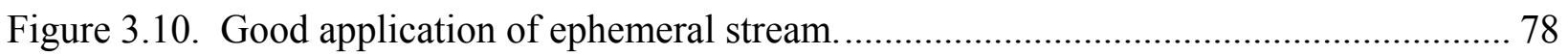

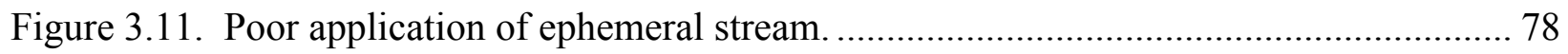

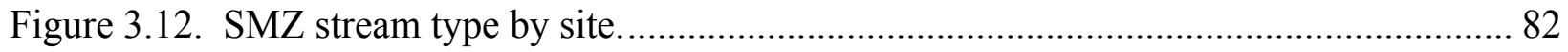

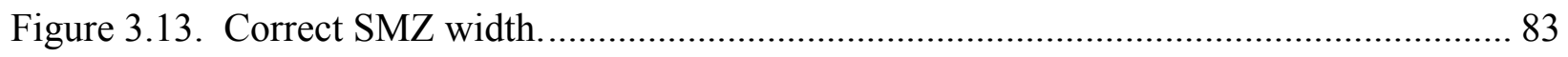

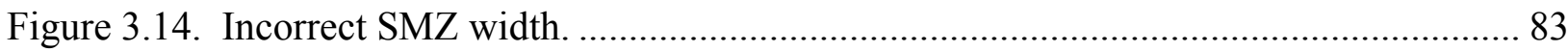

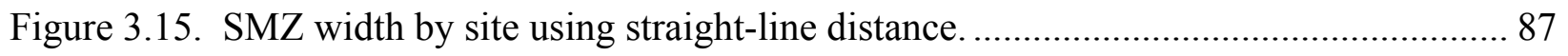

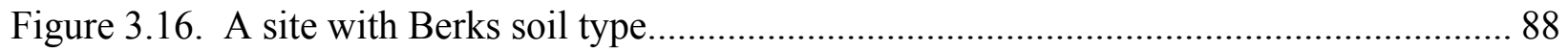

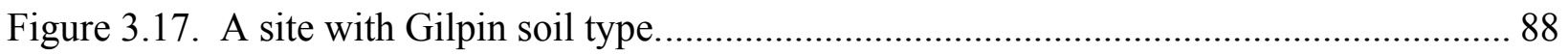

Figure 3.18. Distance raster with topography shown. ………………………………............ 91

Figure A.1. Poor application of waterbars on a skid trail........................................................ 106 
Figure A.2. Good application of outsloping on a skid trail. ........................................... 106

Figure A.3. Poor application of cross drainage in a haul road........................................... 107

Figure A.4. Good application of gravel applied to a haul road.......................................... 107

Figure A. 5. Poor application, effectiveness, and compliance of reclamation in a SMZ. ........ 108

Figure A.6. Good application of culvert installation in a SMZ ........................................ 108

Figure A.7. Poor application and compliance of drainage on a landing............................. 109

Figure A.8. Good application and compliance of reclamation on a landing. ........................ 109 


\section{LIST OF TABLES}

Table 1.1. The relationship of SMZ width (ft) and slope of some northeastern states.

Table 1.2. Relationship of water bar spacing (ft) and slope of skid trails of some northeastern

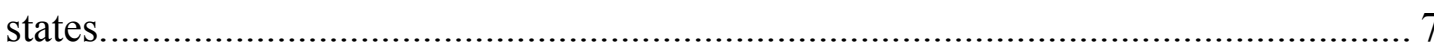

Table 1.3. BMP compliance in some northeastern states. .............................................. 10

Table 1.4. BMP compliance by year in West Virginia....................................................... 10

Table 2.1. Number of samples by forest district......................................................... 16

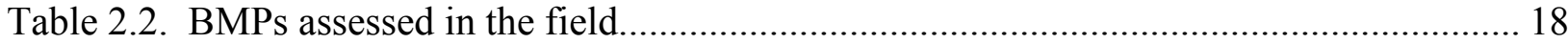

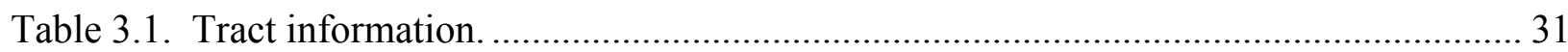

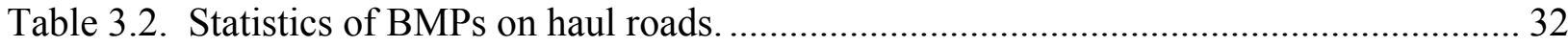

Table 3.3. Means and significance levels of statistics for BMPs measured on haul roads......... 33

Table 3.4. Means and significance levels of percent compliance for BMPs measured on haul

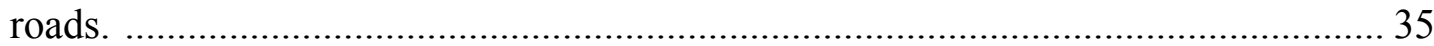

Table 3.5. BMP compliance for haul roads by attribute................................................. 35

Table 3.6. Statistics of variables measured in skid trails..................................................... 36

Table 3.7. Means and significance levels of statistics for BMPs measured on skid trails.......... 38

Table 3.8. Means and significance levels of percent compliance for BMPs measured on skid

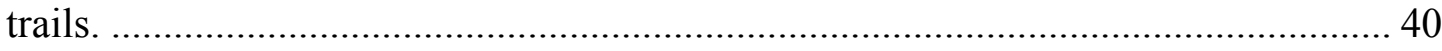

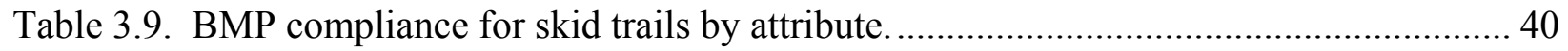

Table 3.10. Frequencies and percentages of BMPs measured on the landings. ...................... 41

Table 3.11. Means and significance levels of statistics for BMPs measured on

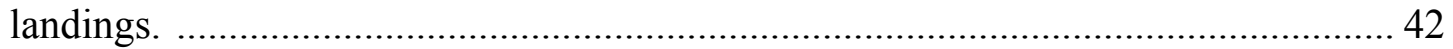


Table 3.12. Means and significance levels of percent compliance for BMPs measured on landings. 43

Table 3.13. BMP compliance for landings by attribute................................................. 44

Table 3.14. Statistics of variables measured within SMZs.................................................. 45

Table 3.15. Means and significance levels of statistics for BMPs measured on SMZs. ........... 47

Table 3.16. Means and significance levels of percent compliance for BMPs measured within

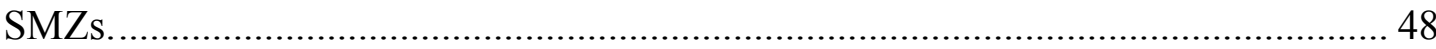

Table 3.17. BMP compliance for SMZs by attribute......................................................... 49

Table 3.18. Means and significance levels of BMP compliance........................................ 50

Table 3.19. Statistics of BMP application and effectiveness on haul roads. .......................... 51

Table 3.20. Means and significance levels of BMP applications on haul roads....................... 53

Table 3.21. Means and significance levels of BMP effectiveness on haul roads. .................... 54

Table 3.22. Statistics of BMPs on skid trails for application and effectiveness...................... 56

Table 3.23. Means and significance levels of BMP applications on skid trails........................58

Table 3.24. Means and significance levels of BMP effectiveness on skid trails..................... 59

Table 3.25. Statistics of BMP application and effectiveness on landings............................ 61

Table 3.26. Means and significance levels of BMP application on landings. ......................... 62

Table 3.27. Means and significance levels of BMP effectiveness on landings. ....................... 63

Table 3.28. Statistics of BMP application and effectiveness in SMZs................................. 65

Table 3.29. Means and significance levels of BMP applications in SMZs. ............................. 66

Table 3.30. Means and significance levels of BMP effectiveness in SMZs............................ 67

Table 3.31. A summary of the questions to Landowners in percentage................................ 71

Table 3.32. Landowner statistics by ownership in percentage. ......................................... 72 
Table 3.33 . Spatial analysis summary by stream type................................................. 81

Table 3.34. Spatial analysis summary by SMZ width. .................................................... 86

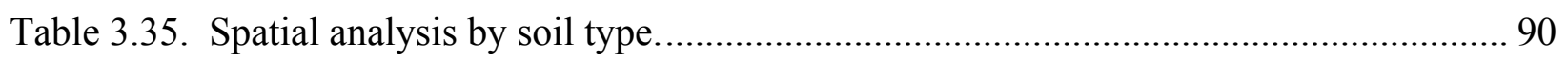

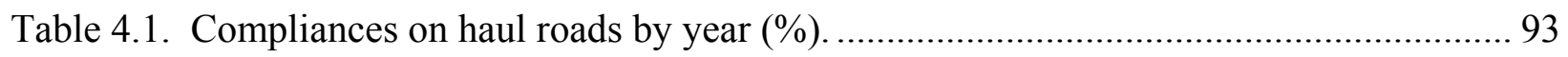

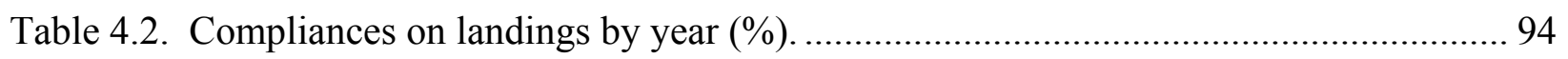

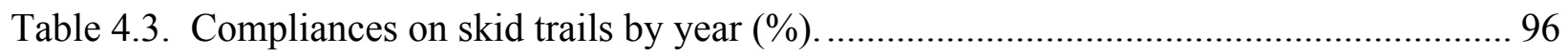

Table 4.4. BMP compliances in West Virginia by year of assessment. ................................. 98 


\section{INTRODUCTION}

Best management practices (BMPs) were developed to prevent or reduce the adverse impacts of forest management activities on water quality while permitting the intended management activities to occur (Phillips et al. 2000). The guidelines vary from state to state, but they all focus on erosion control and water quality. The areas of focus are on landings, haul roads, skid trails, and streamside management zones (SMZs). West Virginia initiated BMPguidelines in the early 1970's, and they have been revised five times since then (Wang et al. 2004). These revisions have enabled the state to reach the guidelines that are used now. The West Virginia Legislature passed the Logging Sediment and Control Act (LSCA) in 1992, which has been implemented into the current revisions. This act specifically mandates logger licensing, logger certification, harvesting operation notification, and enforcement capability for activities causing erosion and sedimentation on logging sites (Wang et al. 2004). The purpose of this act is to decrease erosion and sediment while improving logging practices. The LSCA contains 14 sections to aid loggers in better management plans as well as to set mandates for all logging companies to follow. The West Virginia Division of Forestry (WVDOF) is the agency in charge of overseeing and enforcing the laws in the LSCA. Some of the sections in the LSCA require loggers to obtain a timbering license, job posting on the site, notification prior to harvesting, and reclamation when the harvest is complete. Another important rule is that all timber harvesting jobs require a certified logger on site at all times.

West Virginia has completed four compliance studies since the initiation of the BMP guidelines. In 1981, 16 BMPs were evaluated on 101 logging sites with a checklist (Paff 1981). The second compliance study included 106 sites and was conducted in 1986 (Whipkey and Glover 
1987). This compliance study included two production size classes, and divided the state into three regions. The second evaluation included 26 BMPs. The third evaluation was done in 1990. This evaluation differed from the previous two in that it selected loggers instead of logging sites (Whipkey 1991). The main focus of this evaluation was on protecting West Virginia's streams from any siltation. The fourth evaluation was conducted from May 1995 to November 1996. This evaluation took into consideration the changes made to the WV BMP guidelines in 1995. In this evaluation sites were sampled instead of loggers in six WVDOF Forest Districts.

About ten years have passed since the last assessment. Results from that survey produced low compliance levels for haul roads and skid trails. Since the last assessment, state BMP guidelines were revised three times, specifically giving the WVDOF the authority to issue citations, SMZ buffers, and requiring a certified logger on the job at all times. It is necessary to conduct another statewide assessment of BMP application, effectiveness, and compliance (Wang et al. 2004). BMPs were evaluated for application, effectiveness, and compliance based on sample sites. Application and effectiveness was assessed separately from compliance. This assessment will provide a basis for application and effectiveness of BMPs, which is becoming an increasing concern during assessments in our region. 


\section{CHAPTER 1: LITERATURE REVIEW}

\subsection{Background}

West Virginia passed its own Water Pollution Control Act in 1974 and a state 208 silvicultural technical action committee completed a silvicultural water quality management plan for West Virginia in 1979 (Sherman 1985). Section 208 states that timber harvesting activities are exempt from acquiring a non-point pollution discharge (Yonce 2004). The EPA has since required proof that these BMPs are being implemented (Ryder 2003). The state decided on a voluntary approach to control nonpoint source pollution. The WVDOF implemented a Voluntary Compliance Committee. The WVDOF has used many tactics to educate loggers including workshops and field demonstrations. These acts are used to share new information and to refresh loggers of the BMP guidelines. The workshops and field demonstrations are very beneficial. BMP guidelines are voluntary and compliance is optional. However, some guidelines allow for fines to be issued by the WVDOF for lack of compliance. The idea to keep in mind is that if the voluntary guidelines are not implemented then erosion and non-point source pollution are almost certain to occur.

In 1972, a joint committee was established by the WV chapter of the Society of American Foresters, the WV Sawmill Association, and the Appalachian Hardwood Manufacturers, Inc. (West Virginia Division of Forestry 1986). This committee developed forest practice standards, which included some BMP guidelines (Anonymous 1972). The West Virginia Division of Forestry was responsible for regulating all harvesting activities in the state. State foresters retain the authority to issue citations when necessary. This was a new revision of the guidelines from 2002. The West Virginia Division of Forestry offers loggers a chance to learn more about the 
guidelines by offering workshops and the BMP guideline booklet. This booklet is free of charge and is located at any local Division of Forestry office.

Best Management Practices guidelines have been an important issue in the state of West Virginia for quite some time. The guidelines have been revised many times. To keep up with current problems, the State BMP committee reviews the BMP guidelines at least every three years. This committee is made up of state foresters and other forestry professionals that are appointed by the WVDOF. The main focus of the BMP guidelines seems to be turning toward the protection of the SMZs. These receive a great deal of attention when harvesting operations are going on. An SMZ is defined as "a vegetated land adjacent to perennial, intermittent, and ephemeral streams and ponds or lakes requiring special attention during forestry operations" (West Virginia Division of Forestry, 1997, 2001, 2002). Cutting is allowed in the SMZ, but only in small amounts leaving a certain percentage of basal area. The equipment operations must also be kept to a minimum when removing any cut timber from an SMZ. It is preferred that the cut trees are cabled out of the SMZ instead of building roads into the area.

The principal cause of the degradation of water quality associated with harvesting activities is erosion from highly disturbed areas such as roads and log landings, with eventual sedimentation in streams (Kochenderfer 1997). This is the major reason for adequate application, effectiveness, and compliance of BMPs. As early as 1955 it was stated that without careful placement and installation of roads and landings, sedimentation will increase beyond normal geologic processes (Tebo 1955, Reinhart et al. 1963, Hewlett 1979). These observations require constant monitoring of the use and effectiveness of BMPs. In Vermont, 78 timber harvesting operations were assessed for acceptable management practice (Brynn and Clausen 1991). Schuler and Briggs assessed 42 sites for voluntary application and effectiveness in New York. It is necessary to make the 
distinction between compliance and effectiveness. Effectiveness monitoring determines whether a forest practice actually achieves the desired goal (Ellefson et al 2001). Assessing the effectiveness of the BMPs will determine how well they are working when constructed properly. This is vital information when determining revisions to the guidelines. Changes should be made according to the effectiveness of a BMP reducing sedimentation and erosion.

\subsubsection{Streamside Management Zones}

Best Management Practices regulations are growing ever more important. States are putting more emphasis on the need to have and follow these guidelines. The guidelines have similarities throughout the Northeast. However, there are slight differences from state to state (Table 1.1).

Table 1.1. The relationship of SMZ width (ft) and slope of some northeastern states.

\begin{tabular}{lccccccccccc}
\hline & \multicolumn{10}{c}{ Slope $\%$} \\
\hline & 0 & 10 & 20 & 30 & 40 & 50 & 60 & 70 & 80 & 90 & 100 \\
\hline Maine & 25 & 45 & 65 & 85 & 105 & 125 & 145 & 165 & & & \\
New Hampshire & 50 & 70 & 90 & 110 & 130 & 150 & 170 & 190 & & & \\
Ohio $^{1}$ & 25 & 45 & 65 & 85 & 105 & 125 & 145 & 165 & 185 & 205 & 225 \\
Pennsylvania & $25+$ & $45+$ & 65 & 85 & 105 & 125 & 145 & 165 & & & \\
Virginia & 60 & 70 & 100 & 100 & 100 & 120 & & & & & \\
West Virginia $^{2}$ & 100 & 100 & 25 & & & & & & & & \\
\hline
\end{tabular}

\footnotetext{
${ }^{1}$ Widths are doubled in Critical Areas. These are areas that require extra precaution.

${ }^{2}$ Stream types: Perennial, Intermittent, and Ephemeral.
}

\subsubsection{SMZ Width}

The state of Virginia classifies three different water types when applying SMZs. The widths are different for each type, which include: warm water fisheries, municipal water supplies, and cold water fisheries (Virginia DOF 2004). The widths for the cold-water fisheries are found in Table 1.1. West Virginia calls for SMZs to be 100 feet wide on perennial and intermittent streams. 
Ephemeral streams require a 25-foot buffer (WVDOF 2004). Streamside Management Zone width used to be determined by using slope percentage, but is now simply defined as 100 feet for perennial and intermittent streams and 25 feet for ephemeral streams. This is the main difference between West Virginia and surrounding states. The majority of the surrounding states still use a calculation of slope.

New York State recommends keeping skidders at least 50 feet from a water body. When slopes exceed $10 \%$ they recommend a buffer zone of 100 feet (New York DEC 2004). They also recommend leaving a 50-foot strip that is uncut when a clearcut harvest is being used. When slopes exceed $30 \%$ a 150 -foot buffer zone is to be applied. The state of Maryland also incorporates slope when determining buffer zones.

\subsubsection{Water Bars}

Another major component of the BMPs is the water bars that are located on skid trails. These are very important to short and long-term erosion control. Installation of water bars aided in trail stabilization (Patric 1977, Rothwell 1983). Presence of leaf litter indicated a proper number of water bars for drainage. Water bars should be constructed at the end of every workweek, and before periods of rain is expected. They must also be put in place at the end of the harvest. The spacing of the water bars is in feet. Depending upon the slope of a road the distance between water bars can vary. In general, the states of the Northeast use very similar regulations for spacing of water bars. The only differences show in steeper slopes. New Hampshire and Virginia use the same spacing and continue to use 35 feet at slopes past $25 \%$. Pennsylvania has requirements up to $40 \%$ slopes. This is steeper than any skid trail should be, but if necessary for a short length 
Pennsylvania requires spacing of 30 feet. The requirements for water bars being constructed on skid trails are shown in Table 1.2.

Table 1.2. Relationship of water bar spacing (ft) and slope of skid trails of some northeastern states.

\begin{tabular}{|c|c|c|c|c|c|c|}
\hline & \multicolumn{6}{|c|}{ Slope $\%$} \\
\hline & 2 & 5 & 10 & 15 & 20 & $25 \quad 30 \quad 40$ \\
\hline Maine & $250-400$ & $135-25$ & $0-13$ & $50-8$ & $45-60$ & $<45$ \\
\hline Maryland & Spacing (ft.) & 000/(\% & pe + & & & \\
\hline New Hampshire & 250 & 135 & 80 & 60 & 45 & 35 \\
\hline Ohio & 250 & 135 & 80 & 60 & 45 & 4035 \\
\hline Pennsylvania & 250 & 135 & 80 & 60 & 45 & $4035 \quad 30$ \\
\hline Virginia & 250 & 135 & 80 & 60 & 45 & 35 \\
\hline West Virginia & 100 & 100 & 80 & 60 & 45 & 4035 \\
\hline
\end{tabular}

Maryland uses a simple equation for determining the number of water bars on a skid trail (Maryland Dept. of Environment 2004). West Virginia uses a stricter table for the amount of water bars placed on a skid trail. This table calls for an increase in the amount of water bars placed on a skid trail. This increase shows in the more common slopes. When most skid trails are constructed between two and ten percent, West Virginia has the greatest requirement with water bars needed every 100 feet. This should prove to enhance erosion control. This is also necessary due to West Virginia's steep topography.

\subsubsection{Haul Roads}

Haul roads are a crucial point to any harvest. This road will provide access for transportation of all equipment and will be a high traffic area once harvesting begins. There will be many trips made on this road each day to haul logs to the mill. This is often a point of concern since the public can easily see this area as it connects to public roads. Egan et al (1996) 
addressed the problems of forest road construction related to topography, water management, and lack of planning. Planning of these roads is stressed in the BMP guidelines.

West Virginia guidelines require that a haul road be graveled for 200 feet at a public road entrance. The requirement is that the road must be on a grade of less than $10 \%$. Grades of up to $15 \%$ are allowed for distances less than 200 feet. These segments must also be seeded and mulched after the harvest is complete. When possible, the roads should be located on welldrained soils. Haul roads can be out-sloped up to three percent. This should be watched closely during icy conditions for driver safety.

Haul roads have similar guidelines across the states of the Northeast. The states used in this study follow suit with the guidelines used in West Virginia. The only differences are subtle recommendations. New York recommends curving the haul road near public entrances to reduce the view of the road and landing. Maine's guidelines mention to construct roads during dry periods or when the ground is frozen to reduce erosion. These are recommendations that should be followed during any harvest, but the printed guidelines included them in the aforementioned states.

\subsubsection{Landings}

Landings are an area of much activity. Every piece of equipment passes over the landing numerous times. This area should be kept to a minimum. Landings need to be located on level and well-drained sites. When landings are not maintained properly they can be a major point of erosion and non-point source pollution.

West Virginia guidelines recommend landings be no more than half an acre, with the suggested size being around a quarter of an acre. Landings must be seeded and mulched when the harvest is complete. All approach roads to a landing must be diverted. 
Maryland requires landings to be of a slope of less than $10 \%$. New York recommends keeping landings 200 feet from the road, and placing the long axes perpendicular to the road. This practice can make the area seem smaller than its actual size.

All the states observed use similar guidelines. Try to keep the landing to a minimal area. Place landings out of public view when possible. Divert water from the uphill side of the landing to prevent water from settling on the landing. The landing should be smoothed, seeded, and mulched after the harvest.

\subsubsection{BMP Compliance}

The states of the Northeastern region share similar guidelines concerning BMPs. These states share similar forest types and topography, which means they share similar problems concerning soil erosion. The fact that the BMPs are similar shows that when applied properly these guidelines are effective in controlling soil erosion and non-point source pollution. Overall BMP compliance in Vermont was 64\% (Brynn and Clausen 1991). Maine had an overall compliance rate of 71\% (Briggs et al. 1998). The compliance rate in New York was 74\% (Schuler and Briggs 2000). In 1996 West Virginia had a compliance rate of 63\%. This was down from 1986 and 1991 . The overall compliance for those years was $71 \%$ and $75 \%$ respectively. Table 1.3 shows the compliance rates for some surrounding Northeast states (Wang et al. 2004).

West Virginia compliance rates rank well with other states of the Northeast. The overall compliance is slightly lower than states featured in Table 1.3. It may be because of topography issues and the amount of harvesting that takes place in the state. This might be the reason for the relatively overall low compliance rate in West Virginia. 
Table 1.3. BMP compliance in some northeastern states.

\begin{tabular}{lcccccc}
\hline & Year & Landings & $\begin{array}{c}\text { Skid } \\
\text { trails }\end{array}$ & $\begin{array}{c}\text { Haul } \\
\text { roads }\end{array}$ & SMZs & Overall \\
\hline Maine & 1998 & $77 \%$ & $67 \%$ & $68 \%$ & $66 \%$ & $71 \%$ \\
New York & 2000 & $87 \%$ & $59 \%$ & $78 \%$ & $73 \%$ & $74 \%$ \\
Vermont & 1991 & $80 \%$ & $70 \%$ & $41 \%$ & - & $64 \%$ \\
West & 1996 & $76 \%$ & $62 \%$ & $52 \%$ & - & $63 \%$ \\
Virginia & & & & & & \\
\hline
\end{tabular}

\subsubsection{BMP Compliance in West Virginia}

The compliance rates from previous studies closely resemble that of the surrounding states. These compliance rates are shown in Table 1.4 (Wang et al. 2004).

Table 1.4. BMP compliance by year in West Virginia.

\begin{tabular}{lccc}
\hline Evaluation & $\begin{array}{c}\text { No. of loggers/ } \\
\text { logging sites } \\
\text { observed }\end{array}$ & $\begin{array}{c}\text { No. of BMPs } \\
\text { measured }\end{array}$ & $\begin{array}{c}\text { Overall } \\
\text { compliance } \\
\%\end{array}$ \\
\hline 1981 & 101 & 16 & 59 \\
1986 & 106 & 26 & 71 \\
1991 & 234 & 26 & 75 \\
1996 & 95 & 20 & 63 \\
\hline
\end{tabular}

(From Wang et al, 2004)

The BMP guidelines are well used and compliance has proven to be quite high. This does not mean that every job is perfect. There are still cases where problems arise. The most common problems are no reclamation, no notification, and no licensed logger (Wang et al 2004). These are major problems because an unlicensed logger may not be educated about the use of BMPs. When a job is not reclaimed it looks bad for the whole industry as well as being a source of non-point source pollution. The overall compliance with BMPs increased from 59\% in 1981 to $71 \%$ in 1988 , and 75\% in 1991 (Wang et al 2003). The compliance rate dropped slightly in 1996 to 63\%. This is due to the change in checklists used. There were many fields added in this study. The fields in 
the study that remained the same as the previous years did show slight increases in compliance. The method for this study were consistent with the study in 1996. Logging sites were selected randomly. Ellefson and others stated that site selection and location, access to private property, and consistency in reviews were weaknesses in compliance studies. This study sampled a large percentage of private lands across the state. All sites were assessed by one person for standardization. The checklists were similar to the 1996 survey, but included a few new fields. The SMZ checklist were a major point of interest. The use of water bars was also be studied carefully. The WVDOF revised the BMP guidelines three times since the study in 1996, in 1996, 2001, and again in 2002. This compliance study considers these revisions and takes them into account relative to the previously used checklists.

\subsection{Problems}

This study examined the effectiveness of BMPs, and the interrelationships among BMP compliance or effectiveness and other site factors and was constructed to help the WVDOF determine if BMP guidelines are working. The revisions were intended to aid loggers on harvest operations in West Virginia. Based on the results WVDOF can be better informed about how to make new revisions that better serve the forestry industry.

The new regulations can be examined and the SMZ component will allow the WVDOF to review these guidelines. The spatial analysis component will allow the WVDOF to review what areas are most affected by a harvest. Being able to view the entire site on a map allows foresters and harvesters to better plan for the next harvest. 
Soils are a very important component to any harvest. Soil type varies a great deal across any harvest. By choosing the right site for skid trails and landings, working conditions may be extended when weather is a problem. When planning a harvest the ideal spot for a landing is on a dry site. This information can be gathered by using a soil map of the area. A soil map will also aid in road layout prior to the harvest operation. Planning ahead in these areas can allow a harvest to be carried out more smoothly.

Once this survey is completed, the WVDOF will have an up to date compliance study. This compliance study will cover all of the aspects of typical forest harvesting operations. This information will allow foresters to determine if further revisions are necessary to the BMP guidelines.

- $\quad$ BMP guidelines revised five times

- A new survey to cover revisions

- $\quad$ The new survey will include haul roads, skid trails, landings, and SMZs

- $\quad$ Checklists for all components

- Landowner questionnaire

- $\quad$ Application and Effectiveness checklist

- $\quad$ Statistical analysis of all the data from checklists

- Harvest information from notification forms

\subsection{Objectives}

The main focus of this compliance was the SMZ areas, skid trails, haul roads, and landing sites. These areas are most susceptible to erosion during and post harvest. Soils maps were used to determine where erosion was most likely to take place. The soil type along with the slope of the 
skid trails helped to determine areas of non-point source pollution. This evaluation will help the Division of Forestry to observe aspects of the guidelines that may need improvements. This study was designed to illustrate how changes affect current harvesting operations, and provide information for further revisions of the guidelines. During the study, landowners were surveyed to determine if they were satisfied with the harvest. Private and industrial landowners were included in the survey. This information was useful in determining forester involvement and addressed the concern that foresters are not involved with private landowners during harvest planning. With an increase in forester involvement better, decisions can be made during pre-harvest planning to reduce the amount of non-point source pollution.

(1) The GPS information allowed for a spatial component in the analysis. Data was gathered from each site, then corrected and overlaid on a series of maps. This process allowed for viewing of surrounding land cover and the site soil type. The SMZ areas were viewed on maps to determine areas of special concern. The slope of the SMZ area was measured in the field, but can also be calculated in ArcMap using elevation grids. The slope grid calculated will be of the entire harvest area as well as the SMZ area. This will make it easy to view the slope percentage of any area on the harvest.

(2) Once all the sites were completed, data was analyzed statistically. The information found in the checklists will be run for compliance levels. These levels will be compared to previous studies in West Virginia and surrounding Northeastern states. This will provide an up to date compliance survey for West Virginia.

(3) The SMZ areas have an application and effectiveness checklist. This checklist will review how well the guidelines were applied and how well they work. The fields in the checklist will be ranked depending on their ratings. 
(4) The current study will be completed to help view forester involvement and landowner satisfaction on harvested sites throughout the state of WV. 


\section{CHAPTER 2: MATERIALS AND METHODS}

\subsection{Sites and Sampling Procedures}

Sites were selected randomly from each of six West Virginia forest districts following a sampling protocol used by a previous assessment in the state (Egan et al. 1998). Harvested sites, rather than loggers, were selected for the sample. Sampling time period was from November 2003 to March 2004. Harvesting operations that were started during this time period were used as possible sample sites. This time period was used for each district. A random sample of 30 sites was first chosen from forest district 3. There were 347 harvested sites started in forest district 3 during this time period. Number of sites to be sampled in the other districts, represented by $n$, was determined by using the following formula:

$$
n=\frac{x}{347}(30)
$$

Where $x$ represents the number of harvested sites in a district during the designated time period. The sampled sites in each district represented nearly $10 \%$ of the harvested sites during the sample time period.

Once the sample size was determined, the notification forms were obtained from the district office. A total of 116 sites were surveyed throughout the six forest districts of West Virginia (Table 2.1). 
Table 2.1. Number of samples by forest district.

\begin{tabular}{lcc}
\hline $\begin{array}{l}\text { West Virginia } \\
\text { Forest Districts }\end{array}$ & $\begin{array}{c}\text { Number of Samples } \\
(\mathrm{n})\end{array}$ & $\begin{array}{c}\text { Harvested Sites } \\
(\mathrm{X})\end{array}$ \\
\hline 1 & 24 & 270 \\
2 & 17 & 194 \\
3 & 30 & 347 \\
4 & 10 & 97 \\
5 & 17 & 189 \\
6 & 18 & 195 \\
\hline
\end{tabular}

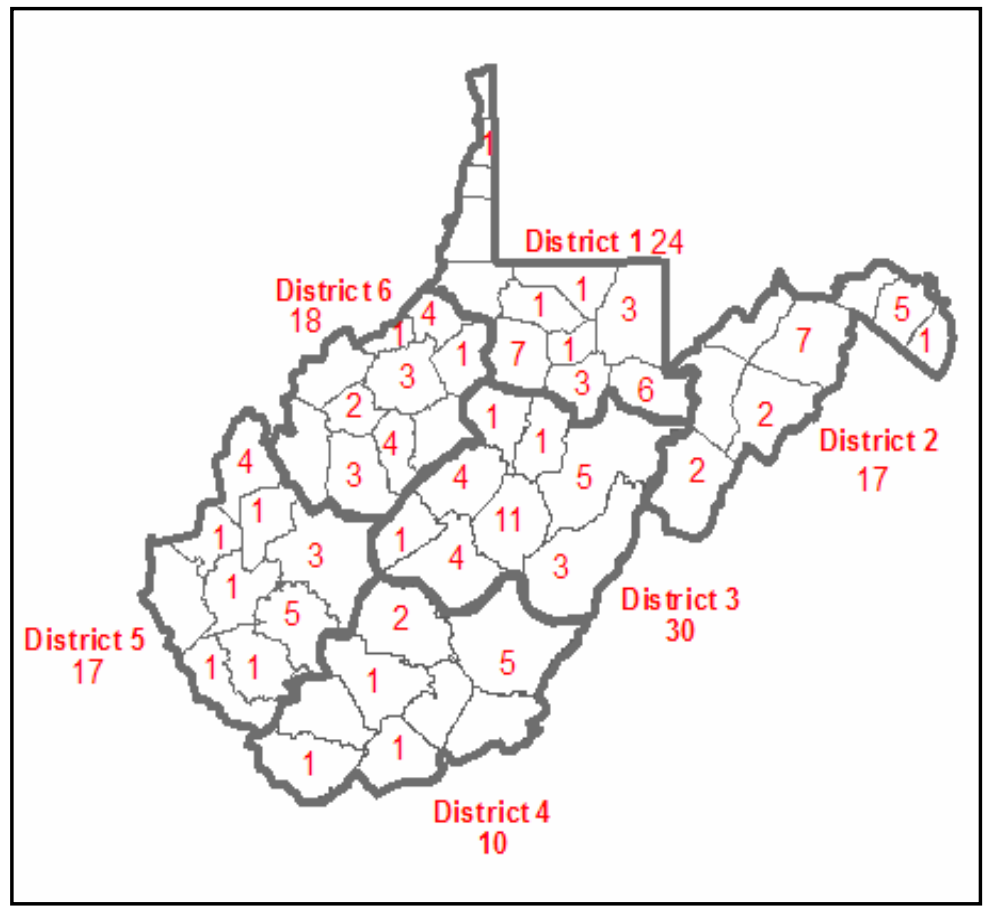

Figure 2.1. Site distribution by county for BMP assessments.

Figure 2.1 shows the number of harvested sites assessed in each county of the state.

Locations of the sites in this survey were based on the random sampling procedures and permission granted by the landowner. If a randomly generated site could not be assessed (over refusal), the random process was repeated until permission was granted to visit the total number of sites designated in a district. Few counties were not sampled due to lack of sample size and lack of landowner permission (Figure 2.1). The sites assessed for BMPs reflect the number of harvested sites completed in each county. Because Forest District 3 usually has the most logging 
activity in the state, it was used for the basis of the study. Forest District 1 had twenty-four sites assessed in its 12 counties. The sites completed in this district were not spread as evenly as those in other districts of the state. Most of the landowners in this district are private landowners. Sites were generated for every county, but landowner permission was not obtained from each county. For example, several sites were generated from Marshall County, but none could be completed due to the lack of permission from landowners.

Each landowner was provided the same questionnaire to determine the satisfaction levels of the harvesting operation and BMPs, and other site-specific information. This questionnaire was administered on site or over the telephone. Questions were asked to determine how the landowner contacted the logger; if the landowner had made any changes to the roads; if they had made special requests of the logger during the harvest; if they observed any BMP violations during the harvest or erosion since the harvest; and if the landowner would recommend the logger to do another harvest.

Information from the notification forms was used to determine tract size, forester involvement, and type of harvest. There are three main types of harvesting methods listed on the WVDOF timber harvesting notification form, including selection or marked timber, diameter limit cut or logger's choice, and clear cut. If more than one type of harvest method occurred on a larger tract, the harvest method of the larger acreage was used.

\subsection{BMP Checklists}

The checklists used in this assessment were similar to those used in the 1996 survey, including the checklists for haul roads, skid trails, landings, and SMZs. Variables or fields in the checklists are the recommended BMP guidelines found in West Virginia. The BMPs assessed in 
the field are shown in Table 2.2. These are the fields assessed for compliance, application, and effectiveness. There were eight separate checklists used in the field for assessment.

Table 2.2. BMPs assessed in the field.

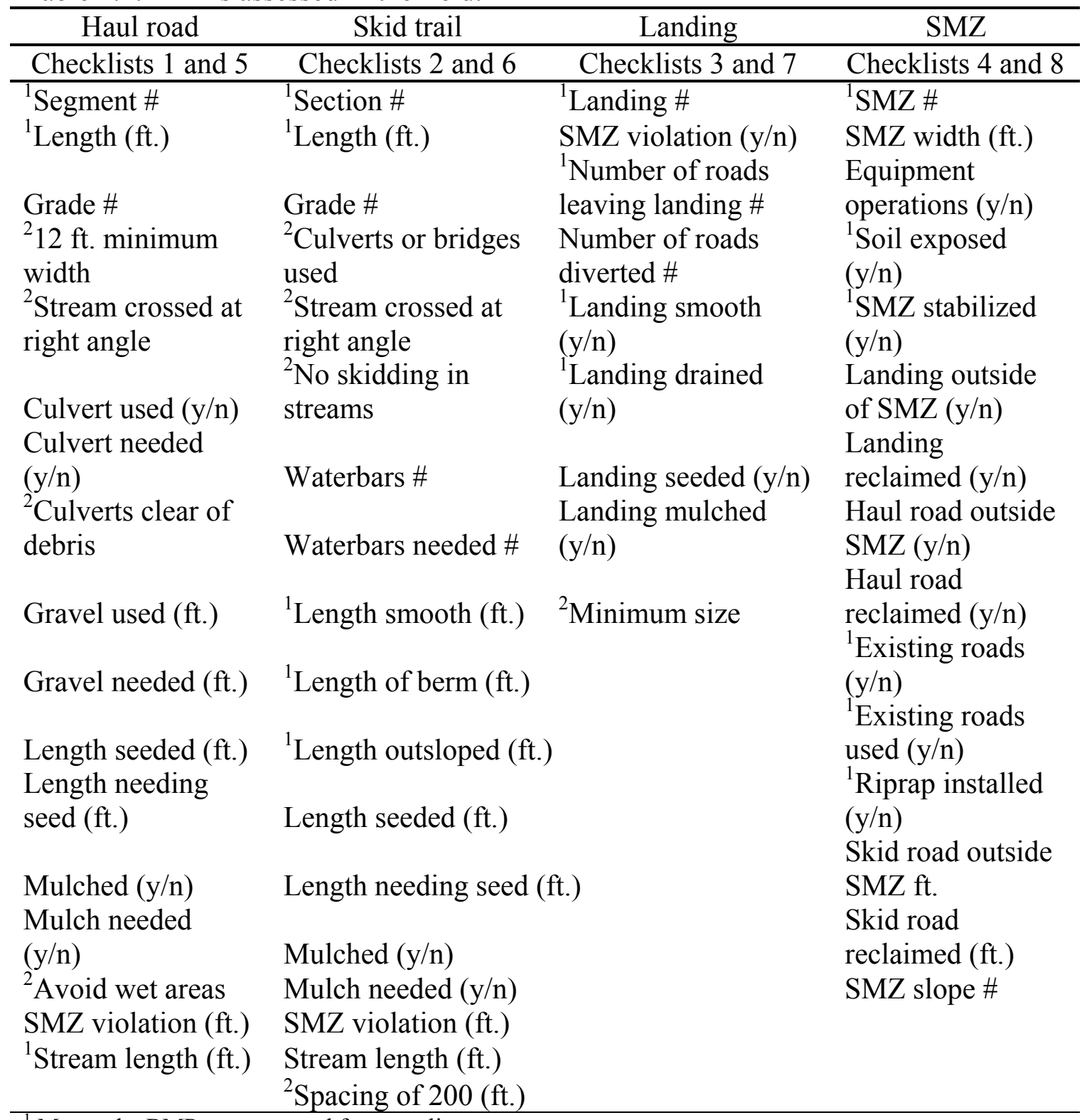

\footnotetext{
${ }^{1}$ Means the BMP was assessed for compliance.

${ }^{2}$ Means the BMP was assessed for application and effectiveness.
} 
Separate checklists were used for application and effectiveness of BMPs on sites that have SMZs. This specifically examines how well the BMPs were constructed and how well they are working over time. Sites with SMZs generally require more precaution during harvesting. Application and effectiveness checklists include similar fields as the compliance checklists, but focus on the major BMPs. Specifically, the appearances of sedimentation or runoff were visually categorized by using these checklists. The applications of the BMPs were ranked 1 to 3: (1)

BMP not used or poor application; (2) BMP attempted with minor deviations; (3) BMP used and correctly applied (Schuler and Briggs 2000). Rankings for the overall effectiveness of the BMPs applied were ranked from 1 to 5: no effect (1), poor (2), fair (3), good (4), and excellent (5) (Ohio DOF 1999). These rankings rate how well the applied BMP is at reducing runoff and sedimentation.

\subsection{BMPs Measured}

\subsubsection{Compliance}

A total of 26 BMPs were measured in the field for each of the four previously mentioned areas. The BMPs measured on haul roads include: length, grade, use of culverts, and use of cross drainages. Haul roads must be graveled for 200 feet at any public road entrances. Haul roads should be less than $10 \%$ grade. This grade may be exceeded for short distances. However, if the grade exceeds $10 \%$ or it was constructed in a SMZ, the haul road must be seeded and mulched. Haul roads must also be graveled for 100 feet on either side of any stream crossing. A haul road should be outsloped when the harvest is complete. Cross drainages should be installed when needed, but generally around every 100 feet. Length of stream was measured when the haul road was parallel to a stream that was in sight. 
The following measurements were taken on skid trails: length, grade, water bars present and needed, length smooth, length of berm, and length outsloped. Skid trails must also be seeded and mulched for the first 100 feet from the landing. Any segments that exceed a $15 \%$ slope or were constructed in a SMZ must be reclaimed. A smooth segment of skid trail should have no ruts or ruts less than six inches deep. Skid trails should be outsloped unless there is a ditch constructed to remove the water from the road. The berm should be removed on outsloped segments to allow the water to run off the road. Streamside Management Zone violations were measured depending on the type of stream. Stream length was measured.

Landings had the following BMPs measured: the number of approach roads diverted, landing smooth, drained, seeded, and mulched. Landings must be diverted from water and should be kept to a minimum size of about a quarter of an acre. Landings should be placed on dry, firm sites when possible and should be located outside SMZs. Smooth landings will be those with ruts less than six inches deep or none at all.

The SMZ checklist included the following measurements: SMZ width, equipment operations, soil exposure, stabilization of soil, and the use of existing roads if applicable. Equipment operations were determined if there was a disturbance with bare soil exposure within a SMZ. If equipment operations expose soil this area should be reclaimed. Skid trails, haul roads, and landings should be built outside of any SMZ; otherwise, it is a BMP violation and the roads or landings must be seeded and mulched. The SMZ width was determined based on the type of stream being affected. The SMZ should have riprap installed at culvert outlets.

Compliance was based on whether the BMPs were met or not. To determine compliance for segments of roads, length was used. A segment was found to be compliant if it met the requirements set in the BMP guidelines. Total length of skid trail was determined for each tract. 
The lengths measured in the field for the checklists were then summed. The length of the segment being analyzed was used to find compliance percent for the other fields. For example, the total length of smooth skid trail was divided by the total length of skid trail measured for a tract. This was used as the compliance percentage for this BMP. The same process was used for all length measurements. Other compliance levels were found the same way. The number of water bars present was divided by the number recommended by the guidelines. This percentage was the compliance rate for this field. This allowed for tract, district, and state compliance levels to be determined. Compliance for landings was similar, but no length measurements were taken. The landings checklist used "Yes" or "No" fields. These were changed to 1 and 0 respectively. Percentage of compliance was computed by dividing the number of fields answered "Yes" by the total number of fields. Streamside Management Zone compliance was found the same way as the three previous checklists. The fields with measurements were divided by the total length or width. Fields answered "Yes" or "No" were assigned the same number system and then divided by the total number of those fields.

\subsubsection{Application and Effectiveness}

By examining application and effectiveness of BMPs a general idea of the practices being performed by loggers was determined. The Maine Forest Service performed a similar study beginning in 2001 on harvested sites (Maine Forest Service). During the study BMP use and effectiveness was evaluated for protection of water quality. Use and effectiveness were assessed separately, as was done during this assessment in West Virginia. The data collected during this assessment will allow for future assessment comparisons. 
Assessing the application and effectiveness of BMPs does not necessarily determine compliance, but monitors the practices that are used in actual harvests throughout the state. Application and effectiveness of BMPs for haul roads were assessed based on pre-defined rankings. Haul roads were checked if they exceeded $10 \%$ grade, or met the minimum width of twelve feet. A ranking of 1 was assigned if a haul road segment was inside of a SMZ. For a perfect ranking the stream crossing should be constructed at a right angle. The haul road should be graveled for 100 feet on either side of the stream crossing. Cross drainages were assessed for proper outsloping for drainage. Gravel was measured at any public road entrance. Culverts were checked to ensure they were clear of debris. Haul roads need to be located on firm sites where drainage is better in order to allow trucks to drive on the road even in the event of precipitation.

A ranking of 2 for application was given if the grades exceed $15 \%$. Effectiveness was ranked from poor to fair if the grades are steeper than $15 \%$ and showed signs of runoff. Skid trails were measured if they were at least 25 feet away from streams or some segments were inside a SMZ. Water bars were assessed for proper spacing and construction. Stream crossings were assessed for the use of culverts or bridges at right angles, where necessary. West Virginia BMP guidelines require no skidding allowed directly in a stream. The trails should be spaced about 200 feet apart. Stabilization of the trails and banks were assessed if the runoff and erosion of the trail bank was prevented.

Application and effectiveness of BMPs on the landing evaluated include: if landings were constructed outside a SMZ or on a dry site, diversion ditches should be constructed to ensure water diversion from a landing, distances were measured to make sure landings were at least 25 feet from streams. Trails coming into landings should have water bars to divert water 
from running onto the landing, all landings should be seeded and mulched, and checked if the landing size was appropriate.

Two main assessments of BMPs application and effectiveness were for width of the SMZ, and equipment usage. The area disturbed in a SMZ should have been seeded, mulched, and smoothed. Any ruts in a SMZ will create low spots for water to run to and create unnatural drainages. There should be minimal cut or fill slopes made in the SMZ, which will disturb the least amount of soil as possible in this area.

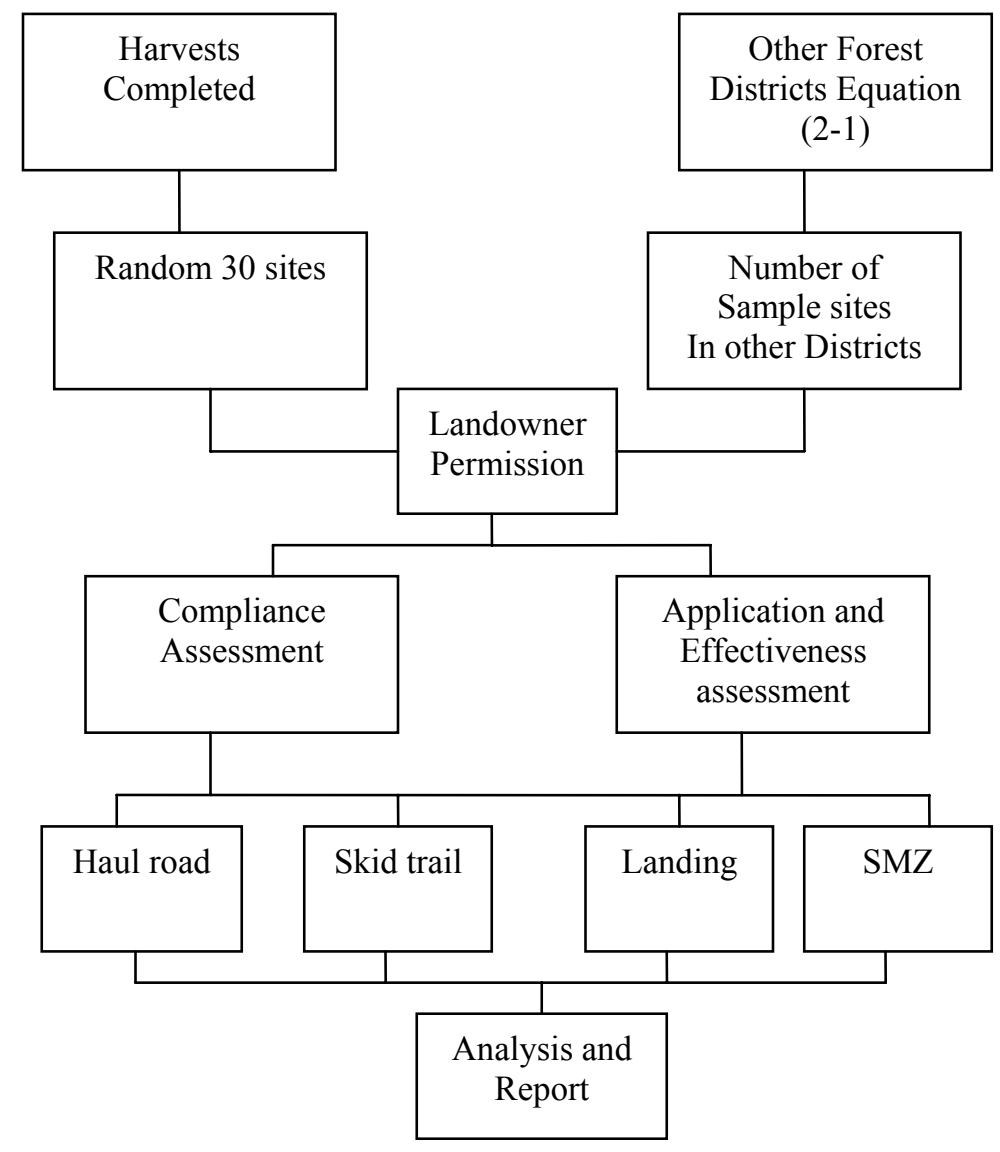

Figure 2.2. Flow Chart of BMP Assessment Process. 


\subsection{Data Collection and Analysis}

Data gathered from the field was entered into Microsoft Excel spreadsheets. Compliance rates were determined using percentages that were compliant on each segment. The length measurements were used to determine the percent compliance of fields such as length smooth, berm removed, length out-sloped, length graveled, and lengths that are within the right grade. Using the same, compliance of water bars was determined. The number of water bars constructed in a segment was divided by the number of water bars that are recommended by the BMP guidelines, and this allowed for the compliance to be found for each segment.

Compliance levels for the landings were found using the same method. The fields measured on the landings were assigned a value of one if the field was answered with a "Yes", and a zero if the field was answered "No". So if the landing was drained it had a value of one. If the landing was not seeded it had a value of zero. These values were divided by the number of landings on a site, and then a percentage of compliance was determined. This process was continued for each field on the landing checklist.

The same process was used for the SMZ checklist, fields answered "Yes" were assigned a value of one, and fields answered "No" were assigned a value of zero. Compliance levels were determined for the fields by using the number of SMZs found on a site, and then by dividing the values assigned to each field into the number of SMZs. There are BMPs that have more emphasis and impacts on erosion control than others. BMPs such as: water bars, seeding and mulching, outsloping, and berm removal on skid trails. Seeding and mulching of landings as well as proper drainage and water diversions should be applied. These BMPs directly affect possible sources of non-point source pollution. They are used on areas of high traffic and soil 
exposure. Measurements taken for these BMPs were used statistically as well as spatially. Using both methods allowed for a better understanding of compliance levels.

Slopes of skid trails, haul roads, and SMZs were measured using a clinometer. Slope measurements of the roads were taken at either grade breaks or curves. This allowed each segment of road to be analyzed separately, since the water bar requirements vary depending on length and slope of a road, each segment can be analyzed for separate compliance. Average slope of the roads and SMZs were determined with these measurements. The average slope of each tract was determined by using an elevation grid of the state provided by the West Virginia GIS Technical Center (wvgis.wvu.edu), which allowed for comparisons of slopes among districts and harvest methods.

Length measurements were done with a laser rangefinder. This accurately determined the lengths of any section of skid trail and haul road. Length measurements also included length of gravel installed and length of seeding and mulching.

Spatial data was collected for landing boundaries, haul roads and skid trails, water bar placement, and any SMZs, by using a GeoXT GPS unit. Data was transferred from the GPS to an office computer where data was viewed and corrected using GPS Pathfinder Office 2.90. Once the GPS points were corrected, they were overlaid onto Digital Raster Graphic (DRG) maps of each site. Digital Orthophoto Quarter Quadrangles (DOQQs) were downloaded and the data was viewed on these maps as well. These maps were obtained from the West Virginia GIS Technical Center (http://wvgis.wvu.edu/).

The size of the landing was one aspect of this analysis. Landing sites are generally a quarter of an acre or smaller. The streams were digitized and buffers were created to determine how much activity there was inside the SMZ. The straight-line distance method was used to 
determine the distance from haul roads, skid trails, and landings from the stream, and SMZ. Each site was also designated to a watershed and a stream that received the runoff. This information allowed for comparison of harvest area to the watershed acreage. Using this data, flow direction and flow accumulation values were also determined. This allowed for stream networks to be constructed and analyzed. Using this network the data collected from the field could be used to analyze interactions with smaller scale drainage basins. A drainage basin of 5.5 acres was used to view stream networks in relation to the harvest. By using this watershed size the site was examined on a smaller scale. This allowed for a better understanding of the factors that affected the harvest such as elevation and topography, as well as the stream network of the watershed. Soil information was derived from both Soil Survey Geographic Database (SSURGO) and State Soil Survey Database (STATSGO) in West Virginia. The SSURGO data is still a work in progress for the state, but the STATSGO data is statewide. The soil maps were examined for soil types that might have been sensitive to disturbance. Soils were viewed to see if road building would have been easier or better in a different location. Soil maps also proved useful when looking at landing sites. The site of the landing could be viewed to see if it was constructed on a well-drained soil. The SMZ areas were also viewed on soil maps to determine the soil type that was most often affected by these areas. This information allowed for review of the compliance rates based on the soil type that was affected. For example, it could be determined if a landing had poor drainage whether it was related to soil type or poor construction. The topography, roads, landings, soils, and surrounding area were viewed to examine the relationships among BMP compliances, application, effectiveness, and harvest and site factors. 
The erosion hazard of a soil was defined as the probability that damage will occur as a result of site preparation and cutting where soil is exposed along roads and other disturbed areas. The ratings for erosion hazard are determined by slope. A rating of "slight" means there is no particular preventions needed. A "moderate" rating means preventions are needed for certain silvicultural activities. A rating of "severe" means that special precautions are needed to control erosion in most silvicultural activities.

Equipment limitation reflects characteristics and conditions of soils that restrict use of equipment generally needed in harvesting and management. The main characteristics considered are slope, stones on surface, rock outcrops, soil wetness, and texture of surface layer. A rating of slight means the kind of equipment and reason of use are not significantly restricted by soil factors. Soil wetness can restrict equipment use, but wet period does not exceed one month. A moderate rating moderately restricts equipment use because of one or more soil factors. If the soil is wet, wetness restricts equipment use for one to three months. A rating of severe means equipment is severely restricted as to the kind of equipment that can be used or reason for use. If the soil is wet, wetness restricts equipment use for more than three months.

Compliance percentages were used to find the average compliance for each site. This made it easy to determine compliance levels among district and for the entire state: while being able to break down the sites and find compliances by each aspect of the harvest and by each segment measured. This information proved useful when looking at other factors affecting the harvest such as the topography and soil types that may cause problems during a harvest. Compliance levels were determined for privately owned land as well as for industry owned land using the same method used in the 1996 study (Egan et al 1998). This allowed for an easy comparison of the two surveys. 
Compliance levels were compared among district, harvest method, forester involvement stream type, and acreage. A general linear model (GLM) was employed to examine how significantly the site or operational variables such as forester involvement, harvest method, and district affect BMP compliance, application, and effectiveness. For the GLM analysis Duncan's model was used since there was more than two variables being compared.

The Statistical Analysis System (SAS) was used to analyze data. Some of the procedures used in SAS include frequencies and means. A GLM model was also employed to determine significant differences among the variables (Equation 3-1). The checklists used in the field had different variables for each aspect of the harvest, but the same GLM model was used for comparison of these checklists.

$$
\begin{aligned}
& Y_{i j k l}=\mu+F_{i}+D_{j}+H_{k}+O_{l}+F D_{i j}+F H_{i k}+D H_{j k}+F O_{i l}+D O_{j l}+\varepsilon_{i j k l} \\
& i=1,2 \\
& j=1,2,3,4,5,6 \\
& k=1,2,3 \\
& l=1,2
\end{aligned}
$$

Where $Y_{i j k l}=l^{\text {th }}$ observation of the measured BMPs and $\mu=$ grand mean of each variable. $F_{i}$ is the effect of the $i^{\text {th }}$ forester involvement factor. This variable shows whether or not either the property owner or the timber owner employed a forester during the harvesting process. Where $D_{j}$ is the effect of the $j^{\text {th }}$ district. The district variable allowed for comparisons to be made among the six districts of the state. And $H_{k}$ is the effect of the $k^{\text {th }}$ harvest method. The harvest method variable determined the most widely used type of harvest among district and the state. 
Where $O_{l}$ is the effect of the $l^{\text {th }}$ ownership factor. Ownership was defined as either private or industrial. $\varepsilon_{i j k l}$ is an error component that represents uncontrolled variability.

Compliance levels were found for each tract using Microsoft Excel. Determining the compliance levels in this way made it easier to compare the results from this study with the results from previous studies. Using this method also allowed for compliance levels to be expanded from each site to each district and even statewide.

The rankings given to each BMP assessed were totaled for that BMP and divided by the sum of the total possible ranking. This value allowed a percentage to be assigned to each BMP that was assessed separately. Assigning percent values to the rankings enabled a better understanding of the results that were determined. An overall percentage for application and effectiveness was also determined by using the data collected. This data was analyzed by different variables to determine any differences. The application and effectiveness levels were incorporated in spatial analysis. Knowledge was gained by analyzing site specific characteristics and the effectiveness of BMPs applied. 


\section{CHAPTER 3: RESULTS}

A total of 116 sites were visited throughout the six forest districts in West Virginia. Tract acreage ranged from 3 to 226 acres in size, with an average of 58 acres (Table 3.1). One hundred segments of haul road were measured on 54 sites. The number of segments measured per site ranged from 1 to 8 with an average of 4 . The average length of the haul road measured per site was 569 feet ranging from 47 to 3612 feet. On the 116 sites there were 738 segments measured ranging from 27 to 477 feet with an average of 171 feet. The average total length of skid trail measured per site was 1,256 feet, with a range of 226 feet to 3,354 feet. There were 131 landings measured ranging from 1 to 4 per site. Average landing size was 0.14 acres, ranging from 0.02 to 0.9 acres.

There were $51 \mathrm{SMZs}$ measured on 34 sites (Table 3.1). A supplemental set of checklists were used to assess the application and effectiveness of BMPs found on these sites. The average width of these SMZs was 44 feet, ranging from 0 to 100 feet. Streamside Management Zone width ranged from 0 to 100 feet, with an average of 45 feet. The slope of SMZs ranged from 0 to $19 \%$, with an average of slope of $6 \%$. The mean average tract slope, which was based on the measurements from each aspect of the harvest, was 7\%, ranging from 2 to $15 \%$.

Foresters were employed on $68 \%$ of the sites visited. Ownership was distributed with $66 \%$ privately owned and 34\% industry owned. Three harvest methods were identified on these sites, including 44\% selection cuts, 36\% diameter-limit cuts, and 20\% clearcuts. A forester either marked these cuts or the logger was able to decide which trees to cut for a selection cut. The logger could only cut a tree if it was a certain size for a diameter-limit cut. Clearcuts were utilized mostly on industrial land, which made it easier to manage the timber on a fixed rotation. 
Table 3.1. Tract information.

\begin{tabular}{lccccc}
\hline Items & $\mathrm{N}$ & Mean & Std. Dev. Minimum Maximum \\
\hline Tract size (acres) & 116 & 58 & 30 & 3 & 226 \\
Haul road segments (\#) & 100 & 4 & 1.5 & 1 & 8 \\
Haul road segment length (ft.) & 100 & 309 & 358 & 47 & 2640 \\
Total haul road length (ft.) & 54 & 569 & 682 & 47 & 3612 \\
Skid trail segments (\#) & 738 & 3 & 1.6 & 1 & 10 \\
Skid trail segment length (ft.) & 738 & 171 & 78 & 27 & 477 \\
Total skid trail length (ft.) & 116 & 1256 & 598 & 226 & 3354 \\
Total number of landings (\#) & 131 & 1.1 & 0.45 & 1 & 4 \\
Landing size (acres) & 116 & 0.14 & 0.1 & 0.02 & 0.9 \\
SMZ width (ft.) & 51 & 45 & 28 & 0 & 100 \\
SMZ slope (\%) & 51 & 6 & 3 & 0 & 19 \\
Average tract slope (\%) & 116 & 7 & 2.8 & 2 & 15 \\
\hline
\end{tabular}

\subsection{BMP Compliances}

\subsubsection{Haul Road Compliance}

Seven BMPs were measured for haul road compliance. Measurements were taken at each site where the logger was responsible for building or maintaining the haul road. The same haul roads were repeatedly used on most of the industry owned lands. Based on the measurements on 51 sites, the average grade of haul road was 5\% ranging from 1 to $17 \%$ (Table 3.2). The average number of cross drainages on the haul roads was (1) while the average number of cross drainages needed was (2). The application of gravel ranged from 0 to 2,640 feet. About $10 \%$ of the haul roads needed to be seeded and mulched due to a steep grade or being constructed in a SMZ. Nearly all of the roads were reclaimed properly, with only two roads not having the proper reclamations. Three percent of the haul roads were constructed inside of a SMZ. 
Table 3.2. Statistics of BMPs on haul roads.

\begin{tabular}{lccccc}
\hline BMP & N & Mean & Std. Dev. & Min. & Max. \\
\hline Grade less than 10\% (\%) & 100 & 4.9 & 3.3 & 1 & 17 \\
Culverts present (\#) & 100 & 0.2 & 0.4 & 0 & 1 \\
Culverts needed (\#) & 100 & 0.2 & 0.4 & 0 & 1 \\
Cross drainages present (\#) & 100 & 1.2 & 1.7 & 0 & 10 \\
Cross drainages needed (\#) & 100 & 2.3 & 3.7 & 0 & 26 \\
Gravel applied (ft.) & 100 & 271 & 343 & 0 & 2640 \\
Gravel needed (ft.) & 100 & 38 & 126 & 0 & 1084 \\
Seed applied (ft.) & 100 & 32 & 82 & 0 & 487 \\
Seed needed (ft.) & 100 & 31 & 81 & 0 & 487 \\
Mulch applied (Y/N) & 100 & 0.15 & 0.36 & 0 & 1 \\
Mulch needed (Y/N) & 100 & 0.1 & 0.3 & 0 & 1 \\
SMZ violation (ft.) & 100 & 7.9 & 32 & 0 & 252 \\
\hline
\end{tabular}

The means and significance levels of the BMPs measured on the haul roads are shown in Table 3.3. Foresters had a positive affect on the amount of gravel applied, gravel needed, cross drainages applied, seed needed, mulch needed, and the length of SMZ violations. Industry owned lands showed a similar trend for these BMPs. There were few major differences among harvest methods. The differences among forest district varied for each BMP. 
Table 3.3. Means and significance levels of statistics for BMPs measured on haul roads. ${ }^{\mathrm{a}}$

Grade less Gravel Gravel Culvert Culvert Cross $\quad$ Cross $\quad$ Seed $\quad$ Seed Mulch Mulch SMZ $^{b}$

Than 15\% Applied Needed Used Needed Drainage Drainage needed Applied Needed Applied Needed Violation

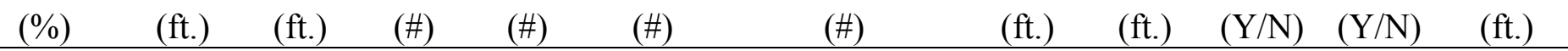

\begin{tabular}{|c|c|c|c|c|c|c|c|c|c|c|c|c|}
\hline \multicolumn{13}{|c|}{ Forester Involvement } \\
\hline Yes & $4.4 \mathrm{~A}$ & $341 \mathrm{~A}$ & $10.5 \mathrm{~B}$ & $0.3 \mathrm{~A}$ & $0.2 \mathrm{~A}$ & $1.3 \mathrm{~A}$ & $2.7 \mathrm{~A}$ & $27.7 \mathrm{~A}$ & $3.8 \mathrm{~B}$ & $0.15 \mathrm{~A}$ & $0.025 \mathrm{~B}$ & $6 \mathrm{~B}$ \\
\hline No & $4.36 \mathrm{~A}$ & $117 \mathrm{~B}$ & $96.3 \mathrm{~A}$ & $0.05 \mathrm{~B}$ & $0.15 \mathrm{~A}$ & $0.5 \mathrm{~B}$ & $1.1 \mathrm{~B}$ & $55.6 \mathrm{~A}$ & $107 \mathrm{~A}$ & $0.18 \mathrm{~A}$ & $0.27 \mathrm{~A}$ & $24 \mathrm{~A}$ \\
\hline \multicolumn{13}{|c|}{ Ownership } \\
\hline Private & $4.2 \mathrm{~A}$ & $238 \mathrm{~A}$ & $60 \mathrm{~A}$ & $0.1 \mathrm{~B}$ & $0.1 \mathrm{~A}$ & $0.9 \mathrm{~A}$ & $1.8 \mathrm{~A}$ & $35 \mathrm{~A}$ & $63 \mathrm{~A}$ & $0.12 \mathrm{~A}$ & $0.17 \mathrm{~A}$ & $18 \mathrm{~A}$ \\
\hline Industrial & 4.7A & $311 \mathrm{~A}$ & $0 \mathrm{~B}$ & $0.4 \mathrm{~A}$ & $0.3 \mathrm{~A}$ & $1.3 \mathrm{~A}$ & $2.6 \mathrm{~A}$ & $43 \mathrm{~A}$ & $0 \mathrm{~B}$ & $0.25 \mathrm{~A}$ & 0B & $2 \mathrm{~B}$ \\
\hline \multicolumn{13}{|c|}{ Harvest Method } \\
\hline Clearcut & $3.3 \mathrm{~A}$ & $155 \mathrm{~A}$ & 0B & $0.3 \mathrm{~A}$ & $0.3 \mathrm{~A}$ & $0 \mathrm{~A}$ & $0.7 \mathrm{~A}$ & $0 \mathrm{~A}$ & $0 \mathrm{~A}$ & $0 \mathrm{~A}$ & $0 \mathrm{~A}$ & $0 \mathrm{~A}$ \\
\hline Diameter Limit & $5.2 \mathrm{~A}$ & $145 \mathrm{~A}$ & 77A & $0.07 \mathrm{~A}$ & $0.14 \mathrm{~A}$ & $1 \mathrm{~A}$ & $1.7 \mathrm{~A}$ & $21 \mathrm{~A}$ & $64 \mathrm{~A}$ & $0.13 \mathrm{~A}$ & $0.1 \mathrm{~A}$ & $17 \mathrm{~A}$ \\
\hline Selection & $4.2 \mathrm{~A}$ & $312 \mathrm{~A}$ & $31 \mathrm{AB}$ & $0.25 \mathrm{~A}$ & $0.19 \mathrm{~A}$ & $1.1 \mathrm{~A}$ & $2.3 \mathrm{~A}$ & $46 \mathrm{~A}$ & $36 \mathrm{~A}$ & $0.19 \mathrm{~A}$ & $0.25 \mathrm{~A}$ & $12 \mathrm{~A}$ \\
\hline \multicolumn{13}{|c|}{ Forest District } \\
\hline 1 & $2.6 \mathrm{~B}$ & $279 A$ & $3 \mathrm{~B}$ & $0.2 \mathrm{~A}$ & $0.1 \mathrm{~A}$ & $0.5 \mathrm{~A}$ & $1.1 \mathrm{~A}$ & $52 \mathrm{~A}$ & $36 \mathrm{AB}$ & $0.3 \mathrm{~A}$ & $0.2 \mathrm{~B}$ & $10 \mathrm{~B}$ \\
\hline 2 & $4 \mathrm{AB}$ & $151 \mathrm{~A}$ & $53 \mathrm{AB}$ & $0.1 \mathrm{~A}$ & $0.2 \mathrm{~A}$ & $0.8 \mathrm{~A}$ & $1.2 \mathrm{~A}$ & $45 \mathrm{~A}$ & $89 \mathrm{~A}$ & $0.1 \mathrm{~A}$ & $0.2 \mathrm{~B}$ & $6 \mathrm{~B}$ \\
\hline 3 & $5 \mathrm{AB}$ & $429 \mathrm{~A}$ & OB & $0.3 \mathrm{~A}$ & $0.3 \mathrm{~A}$ & $1.7 \mathrm{~A}$ & $3.6 \mathrm{~A}$ & $14 \mathrm{~A}$ & $\mathrm{OB}$ & $0.1 \mathrm{~A}$ & OB & OB \\
\hline 4 & $6.5 \mathrm{AB}$ & $195 \mathrm{~A}$ & $136 \mathrm{~A}$ & $0 \mathrm{~A}$ & $0 \mathrm{~A}$ & $2.3 \mathrm{~A}$ & $3 \mathrm{~A}$ & $48 \mathrm{~A}$ & OB & $0 \mathrm{~A}$ & OB & 0B \\
\hline 5 & $7 \mathrm{~A}$ & $157 \mathrm{~A}$ & $157 \mathrm{~A}$ & -- & -- & $0.7 \mathrm{~A}$ & $1.3 \mathrm{~A}$ & $0 \mathrm{~A}$ & OB & $0 \mathrm{~A}$ & $\mathrm{OB}$ & OB \\
\hline 6 & $6 \mathrm{AB}$ & $151 \mathrm{~A}$ & $151 \mathrm{~A}$ & $0 \mathrm{~A}$ & $0 \mathrm{~A}$ & $0.4 \mathrm{~A}$ & $0.6 \mathrm{~A}$ & $68 \mathrm{~A}$ & $98 \mathrm{~A}$ & $0.4 \mathrm{~A}$ & $0.6 \mathrm{~A}$ & $98 \mathrm{~A}$ \\
\hline
\end{tabular}

${ }^{\mathrm{a}}$ Means with the same letter in a group of a column are not significantly different at $\alpha=0.05$ (ANOVA).

${ }^{\mathrm{b}} \mathrm{SMZ}$ violation is the length in feet of haul road which was measured in the SMZ. 
The means and significant levels of compliance were summarized for each BMP measured on the haul roads (Table 3.4). A significant difference was found between forester involvement and no forester involved for the seed applied to haul roads $(\mathrm{F}=8.25 ; \mathrm{df}=1,20 ; \mathrm{P}=0.0140)$. A significant difference was found between harvest method and district for the BMPs of seed and mulch applied. Forester involvement significantly affected the overall BMP compliance on haul roads $(\mathrm{F}=5.95 ; \mathrm{df}=1,53 ; \mathrm{P}=0.0188)$. However, the ownership and harvest method did not significantly affect all the BMP compliance categories on haul roads. The BMP of grade less than $10 \%$ on haul road was significantly different between districts $1-4$ and districts $5-6(\mathrm{~F}=2.80$; $\mathrm{df}=5,53 ; \mathrm{P}=0.0280$ ). However, the overall $\mathrm{BMP}$ compliance on haul roads was not significant between the districts.

Compliance for individual BMPs were separated between private and industry lands (Table 3.5). This method made it easier to compare with the results of the 1996 study. Compliance was analyzed for sites by ownership. Compliance levels were generally higher on industry owned lands compared to privately owned lands for each BMP (Table 3.5). The results from this assessment show that the majority of the BMPs were found to be in compliance. The road grades were kept to below the recommended grade of $10 \%$ on $88 \%$ of surveyed sites. Culverts and/or bridges were used when necessary on $86 \%$ of the sites. The presence of cross drainages had the least compliance on $50 \%$ of surveyed sites. Gravel was applied to haul roads the majority of the time with $92 \%$ compliance. Reclamation of the road (seed and mulch) was completed when necessary on $82 \%$ and $80 \%$ of the sites. Roads were constructed outside of the SMZ on $82 \%$ of sampled sites (Table 3.5). Major differences between industry and private sites were measured relative to the presence of gravel, seed applied, and distance from the SMZ, in which privately 
owned lands showed much lower compliance levels with presence of gravel (28\%), seed applied (70\%), and distance from SMZ (35\%).

Table 3.4. Means and significance levels of percent compliance for BMPs measured on haul roads. ${ }^{\text {a }}$

Grade less Gravel Culvert Cross Seed Mulch Length out Compliance than 10\% Applied Used Drainage Applied Applied of SMZ

\begin{tabular}{|c|c|c|c|c|c|c|c|c|}
\hline \multicolumn{9}{|c|}{ Forester Involvement } \\
\hline Yes & $97 \mathrm{~A}$ & $99 \mathrm{~A}$ & $96 \mathrm{~A}$ & $58 \mathrm{~A}$ & $100 \mathrm{~A}$ & $100 \mathrm{~A}$ & $47 \mathrm{~A}$ & $87 \mathrm{~A}$ \\
\hline No & $94 \mathrm{~A}$ & $98 \mathrm{~A}$ & $33 \mathrm{~A}$ & $40 \mathrm{~A}$ & $29 B$ & $29 B$ & $18 \mathrm{~A}$ & $68 \mathrm{~B}$ \\
\hline \multicolumn{9}{|c|}{ Ownership } \\
\hline Private & $95 \mathrm{~A}$ & $98 \mathrm{~A}$ & $60 \mathrm{~A}$ & $50 \mathrm{~A}$ & $67 \mathrm{~A}$ & $58 \mathrm{~A}$ & $25 \mathrm{~A}$ & $78 \mathrm{~A}$ \\
\hline Industrial & $100 \mathrm{~A}$ & $100 \mathrm{~A}$ & $94 \mathrm{~A}$ & $58 \mathrm{~A}$ & $100 \mathrm{~A}$ & $100 \mathrm{~A}$ & $50 \mathrm{~A}$ & $85 \mathrm{~A}$ \\
\hline \multicolumn{9}{|c|}{ Harvest Method } \\
\hline Clearcut & $100 \mathrm{~A}$ & $100 \mathrm{~A}$ & $100 \mathrm{~A}$ & $40 \mathrm{~A}$ & $100 \mathrm{~A}$ & $100 \mathrm{~A}$ & -- & $86 \mathrm{~A}$ \\
\hline Diameter Limit & $94 \mathrm{~A}$ & $96 \mathrm{~A}$ & $50 \mathrm{~A}$ & $67 \mathrm{~A}$ & $67 \mathrm{~A}$ & $50 \mathrm{~A}$ & $29 \mathrm{~A}$ & $79 \mathrm{~A}$ \\
\hline Selection & $96 \mathrm{~A}$ & $100 \mathrm{~A}$ & $69 \mathrm{~A}$ & $47 \mathrm{~A}$ & $82 \mathrm{~A}$ & $78 \mathrm{~A}$ & $28 \mathrm{~A}$ & $79 \mathrm{~A}$ \\
\hline \multicolumn{9}{|c|}{ District } \\
\hline 1 & $100 \mathrm{~A}$ & $100 \mathrm{~A}$ & $100 \mathrm{~A}$ & $44 \mathrm{~A}$ & $86 \mathrm{~A}$ & $83 \mathrm{AB}$ & $70 \mathrm{~A}$ & $85 \mathrm{~A}$ \\
\hline 2 & $100 \mathrm{~A}$ & 97A & $33 \mathrm{~A}$ & $43 \mathrm{~A}$ & $25 \mathrm{~B}$ & $25 \mathrm{~B}$ & 29B & $67 \mathrm{~A}$ \\
\hline 3 & $100 \mathrm{~A}$ & $100 \mathrm{~A}$ & $95 \mathrm{~A}$ & $51 \mathrm{~A}$ & $100 \mathrm{~A}$ & $100 \mathrm{~A}$ & -- & $83 \mathrm{~A}$ \\
\hline 4 & $100 \mathrm{~A}$ & $91 \mathrm{~A}$ & -- & $75 \mathrm{~A}$ & $100 \mathrm{~A}$ & -- & -- & $89 \mathrm{~A}$ \\
\hline 5 & $67 \mathrm{~B}$ & $100 \mathrm{~A}$ & -- & $50 \mathrm{~A}$ & -- & -- & -- & $78 \mathrm{~A}$ \\
\hline 6 & $80 \mathrm{AB}$ & $100 \mathrm{~A}$ & -- & $67 \mathrm{~A}$ & $75 \mathrm{AB}$ & $67 \mathrm{AB}$ & $0 \mathrm{C}$ & $70 \mathrm{~A}$ \\
\hline
\end{tabular}

Table 3.5. BMP compliance for haul roads by attribute.

\begin{tabular}{lccc}
\hline & \multicolumn{2}{c}{$\begin{array}{c}\text { Sites in } \\
\text { Compliance (\%) }\end{array}$} & $\begin{array}{c}\text { Overall haul road } \\
\text { Compliance (\%) }\end{array}$ \\
\hline Attribute & Private & Industry & \\
Grade less than 10\% & 81 & 98 & 88 \\
Culvert/bridge used at stream & 81 & 92 & 86 \\
Presence of cross drainage & 48 & 52 & 50 \\
Presence of gravel & 28 & 98 & 92 \\
Seed applied & 70 & 93 & 82 \\
Mulch applied & 71 & 88 & 80 \\
Outside SMZ & 35 & 98 & 82 \\
\hline
\end{tabular}




\subsubsection{Skid Trail Compliance}

Measurements were taken on at least the first 500 feet of each skid trail leaving the landing. The measurements were also taken on each spur or each trail constructed off of the first 500 feet measured, and could possibly produce the most erosion coming into the landing area. Of the total length measured only 2,816 feet exceeded a $20 \%$ grade with the maximum grade measured being 24\% (Table 3.6). There were 931 water bars located, while the recommended number of water bars needed was 1,465 . The amount of skid trail that was considered smooth was $88 \%$. Sixty-one percent of the skid trails measured were outsloped. However, only $40 \%$ of them had the berm removed for proper drainage. The average length of seeded skid trail segments was 54 feet. The average length needing seed was 17 feet. Mulching requirements were met on $82 \%$ of the private lands, and $58 \%$ of the industry lands. The length of trails that violated the SMZ was 2,193 feet. This means the trail either crossed the stream or ran parallel to it within the designated SMZ. Skid trails had a range of compliance from $21 \%$ to $99 \%$, and an average of $70 \%$.

Table 3.6. Statistics of variables measured in skid trails.

\begin{tabular}{|c|c|c|c|c|c|}
\hline BMP & $\mathrm{N}$ & Mear & Std. De & Min. & Max. \\
\hline Grade less than $20 \%(\%)$ & 853 & 8.2 & 5.2 & 0 & 24 \\
\hline Water bars present (\#) & 853 & 1.1 & 1.3 & 0 & 11 \\
\hline Water bars needed (\#) & 853 & 1.7 & 1.1 & 0 & 10 \\
\hline Length smooth (ft.) & 853 & 157 & 88 & 0 & 477 \\
\hline Length of Berm removed (ft.) & 853 & 103 & 103 & 0 & 477 \\
\hline Length outsloped (ft.) & 853 & 114 & 103 & 0 & 471 \\
\hline Seed applied (ft.) & 853 & 54 & 83 & 0 & 405 \\
\hline Seed needed (ft.) & 853 & 17 & 38 & 0 & 369 \\
\hline SMZ violation (ft.) & 853 & 2.6 & 22 & 0 & 303 \\
\hline
\end{tabular}

There were significant differences in grade less than $20 \%$ of skid trails among districts. Nearly twice as many water bars were applied with forester involvement with a value of 1.2 $(\mathrm{F}=2.88 ; \mathrm{df}=1,852 ; \mathrm{P}=0.0188)$. Industrial lands had used nearly twice as many water bars as did 
private lands, with a value of 1.4 water bars per trail segment $(\mathrm{F}=9.60 ; \mathrm{df}=1,852 ; \mathrm{P}=0.0020)$ (Table 3.7). There was a significant difference in the length of berm that was removed with forester involvement and ownership, and a significant difference also existed in the length of skid trail that needed to be seeded. Harvest method also significantly affected most of the BMPs measured on skid trails. District four had a significantly higher number of water bars applied than the other districts $(\mathrm{F}=2.43 ; \mathrm{df}=5,852 ; \mathrm{P}=0.0334)$. Average length of smooth trail was greatest in District two and was significantly higher than the other districts $(\mathrm{F}=16.14 ; \mathrm{df}=5,852 ; \mathrm{P}=0.0001)$. The amount of berm removed in District five differed significantly from other districts $(\mathrm{F}=5.55 ; \mathrm{df}=5,852 ; \mathrm{P}=0$ .0001). District two had the most skid trail that was outsloped with 176 feet on average $(\mathrm{F}=7.48$; $\mathrm{df}=5,852 ; \mathrm{P}=0.0001)$. Districts two and six had the greatest amount of stream length that was violated by skid trails. 
Table 3.7. Means and significance levels of statistics for BMPs measured on skid trails. ${ }^{\text {a }}$

\begin{tabular}{|c|c|c|c|c|c|c|c|c|c|}
\hline & $\begin{array}{c}\text { Grade less } \\
\text { Than } 20 \% \\
(\%)\end{array}$ & $\begin{array}{c}\text { Water bars } \\
\text { Applied } \\
(\#)\end{array}$ & $\begin{array}{c}\text { Water bars } \\
\text { Needed } \\
(\#)\end{array}$ & $\begin{array}{l}\text { Length } \\
\text { Smooth } \\
(\mathrm{ft} .)\end{array}$ & $\begin{array}{l}\text { Length } \\
\text { of Berm } \\
(\mathrm{ft} .)\end{array}$ & $\begin{array}{c}\text { Length } \\
\text { Outsloped } \\
\text { (ft.) }\end{array}$ & $\begin{array}{c}\text { Length } \\
\text { Seeded } \\
\text { (ft.) }\end{array}$ & $\begin{array}{c}\text { Seed } \\
\text { Needed } \\
\text { (ft.) }\end{array}$ & $\begin{array}{c}\mathrm{SMZ}^{\mathrm{b}} \\
\text { Violation } \\
(\mathrm{ft} .) \\
\end{array}$ \\
\hline \multicolumn{10}{|c|}{ Forester Involvement } \\
\hline Yes & $8.1 \mathrm{~A}$ & $1.2 \mathrm{~A}$ & $1.8 \mathrm{~A}$ & $160 \mathrm{~A}$ & $109 \mathrm{~A}$ & $114 \mathrm{~A}$ & $56 \mathrm{~A}$ & $14 \mathrm{~B}$ & $1.5 \mathrm{~B}$ \\
\hline No & $8.5 \mathrm{~A}$ & $0.8 \mathrm{~B}$ & $1.6 \mathrm{~A}$ & $149 \mathrm{~A}$ & $88 \mathrm{~B}$ & $113 \mathrm{~A}$ & $51 \mathrm{~A}$ & $23 \mathrm{~A}$ & $5.3 \mathrm{~A}$ \\
\hline \multicolumn{10}{|c|}{ Ownership } \\
\hline Private & $8.1 \mathrm{~A}$ & $0.9 \mathrm{~B}$ & $1.7 \mathrm{~A}$ & $163 \mathrm{~A}$ & $95 \mathrm{~B}$ & $123 \mathrm{~A}$ & $57 \mathrm{~A}$ & $18 \mathrm{~A}$ & $3.5 \mathrm{~A}$ \\
\hline Industrial & $8.4 \mathrm{~A}$ & $1.4 \mathrm{~A}$ & $1.7 \mathrm{~A}$ & $146 \mathrm{~B}$ & $119 A$ & $97 \mathrm{~B}$ & $48 \mathrm{~A}$ & $15 \mathrm{~A}$ & $0.7 \mathrm{~A}$ \\
\hline \multicolumn{10}{|c|}{ Harvest Method } \\
\hline Clearcut & $7.2 \mathrm{~B}$ & $1.3 \mathrm{~A}$ & $1.6 \mathrm{~A}$ & $150 \mathrm{~A}$ & $121 \mathrm{~A}$ & 108B & $42 \mathrm{~B}$ & $16 \mathrm{~B}$ & $0 \mathrm{~A}$ \\
\hline Diameter Limit & $8.9 \mathrm{~A}$ & $1 \mathrm{~B}$ & $1.7 \mathrm{~A}$ & $149 \mathrm{~A}$ & $109 \mathrm{AB}$ & $94 B$ & $59 \mathrm{~A}$ & $23 \mathrm{~A}$ & $3 \mathrm{~A}$ \\
\hline Selection & $7.9 \mathrm{~B}$ & $1.1 \mathrm{AB}$ & $1.7 \mathrm{~A}$ & $165 \mathrm{~A}$ & $92 \mathrm{~B}$ & $131 \mathrm{~B}$ & $55 \mathrm{AB}$ & $13 \mathrm{~B}$ & $3 \mathrm{~A}$ \\
\hline \multicolumn{10}{|c|}{ Forest District } \\
\hline 1 & $7 \mathrm{~B}$ & $1 \mathrm{BC}$ & $1.8 \mathrm{~A}$ & $176 \mathrm{AB}$ & $97 \mathrm{~B}$ & $125 \mathrm{~B}$ & $54 \mathrm{BC}$ & $11 \mathrm{CD}$ & $2.3 \mathrm{AB}$ \\
\hline 2 & 7.8AB & $0.8 \mathrm{C}$ & $1.9 \mathrm{~A}$ & $196 \mathrm{~A}$ & $102 \mathrm{~B}$ & $176 \mathrm{~A}$ & $60 \mathrm{~B}$ & $22 \mathrm{AB}$ & $7 \mathrm{~A}$ \\
\hline 3 & $8.6 \mathrm{~A}$ & $1.2 \mathrm{~B}$ & $1.4 \mathrm{~B}$ & $118 \mathrm{D}$ & $95 \mathrm{~B}$ & 100BC & 28D & 13BCD & $0.1 \mathrm{~B}$ \\
\hline 4 & $8.8 \mathrm{~A}$ & $1.7 \mathrm{~A}$ & $1.8 \mathrm{~A}$ & $143 \mathrm{C}$ & $100 \mathrm{~B}$ & 110B & 43BCD & $6 \mathrm{D}$ & OB \\
\hline 5 & $8.7 \mathrm{~A}$ & $1 \mathrm{BC}$ & $1.9 \mathrm{~A}$ & $162 \mathrm{BC}$ & $150 \mathrm{~A}$ & $82 \mathrm{C}$ & $34 \mathrm{CD}$ & $21 \mathrm{ABC}$ & $1.1 \mathrm{AB}$ \\
\hline 6 & $9 \mathrm{~A}$ & $1.1 \mathrm{BC}$ & $1.9 \mathrm{~A}$ & 168B & $88 \mathrm{~B}$ & $98 \mathrm{BC}$ & $118 \mathrm{~A}$ & $29 \mathrm{~A}$ & $5.8 \mathrm{AB}$ \\
\hline
\end{tabular}


The district variable significantly affected the compliance of water bars applied ( $\mathrm{F}=2.50$; $\mathrm{df}=1,115 ; \mathrm{P}=0.0365)$. The compliance of mulch applied was determined by the length of the skid trail that had been mulched where needed. The compliance level of $100 \%$ in District six was significantly different from other districts $(\mathrm{F}=4.25 ; \mathrm{df}=5,115 ; \mathrm{P}=0.0017)$. Districts also showed significant differences for the BMP of seed applied, with District six presenting 96\% compliance ( $\mathrm{F}=5.44 ; \mathrm{df}=5,115 ; \mathrm{P}=0.0002)$. However, District six had the lowest compliance level for length of skid trail being constructed outside of the SMZ. The overall BMP compliance on the skid trails was significantly different among district, ranging from $59 \%$ in District five to $82 \%$ in District four. Significant differences were found among the interaction between forester and district for the length of skid trail outsloped.

The compliance levels of BMPs on skid trails between private owners and industry owners showed more variability than did haul roads (Table 3.9). Privately owned lands had higher compliance levels for length of berm removed (45\%), length outsloped (71\%), and for number of segments where mulch was applied (82\%). However, for the variables grade less than $20 \%$, water bars applied, seed applied, and length outside of SMZ, industry owned lands were more compliant than private owned lands. 
Table 3.8. Means and significance levels of percent compliance for BMPs measured on skid trails. $^{\text {a }}$

Grade less Water bars Length Length Length Length Mulch Length Compliance

Than Applied Smooth of Berm Outsloped Seeded Applied out of

$20 \%$

SMZ

\begin{tabular}{|c|c|c|c|c|c|c|c|c|c|}
\hline \multicolumn{10}{|c|}{ Forester Involvement } \\
\hline Yes & $91 \mathrm{~A}$ & $55 \mathrm{~A}$ & $92 \mathrm{~A}$ & $37 \mathrm{~A}$ & $64 \mathrm{~A}$ & $65 \mathrm{~A}$ & $60 \mathrm{~A}$ & 57 & $67 \mathrm{~A}$ \\
\hline No & $83 \mathrm{~A}$ & $44 \mathrm{~B}$ & $92 \mathrm{~A}$ & $44 \mathrm{~A}$ & $73 \mathrm{~A}$ & $63 \mathrm{~A}$ & $59 \mathrm{~A}$ & 43 & $67 \mathrm{~A}$ \\
\hline \multicolumn{10}{|c|}{ Ownership } \\
\hline Private & $84 \mathrm{~A}$ & $45 \mathrm{~B}$ & $93 \mathrm{~A}$ & $45 \mathrm{~A}$ & $70 \mathrm{~A}$ & $66 \mathrm{~A}$ & $65 \mathrm{~A}$ & $45 \mathrm{~A}$ & $69 \mathrm{~A}$ \\
\hline Industrial & $93 \mathrm{~A}$ & $65 \mathrm{~A}$ & $90 \mathrm{~A}$ & $26 B$ & $61 \mathrm{~A}$ & $60 \mathrm{~A}$ & $50 \mathrm{~A}$ & $63 \mathrm{~A}$ & $65 \mathrm{~A}$ \\
\hline
\end{tabular}

Harvest Method

\begin{tabular}{lccccccccc}
\hline Clearcut & $95 \mathrm{~A}$ & $62 \mathrm{~A}$ & $94 \mathrm{~A}$ & $26 \mathrm{~B}$ & $68 \mathrm{~A}$ & $70 \mathrm{~A}$ & $61 \mathrm{~A}$ & $100 \mathrm{~A}$ & $69 \mathrm{~A}$ \\
$\begin{array}{l}\text { Diameter } \\
\text { Limit }\end{array}$ & $88 \mathrm{~A}$ & $48 \mathrm{~B}$ & $89 \mathrm{~A}$ & $37 \mathrm{AB}$ & $60 \mathrm{~A}$ & $61 \mathrm{~A}$ & $58 \mathrm{~A}$ & $33 \mathrm{~A}$ & $63 \mathrm{~A}$ \\
Selection & $83 \mathrm{~A}$ & $51 \mathrm{AB}$ & $94 \mathrm{~A}$ & $47 \mathrm{~A}$ & $73 \mathrm{~A}$ & $64 \mathrm{~A}$ & $61 \mathrm{~A}$ & $62 \mathrm{~A}$ & $70 \mathrm{~A}$
\end{tabular}

Forest District

\begin{tabular}{lccccccccc}
\hline 1 & $97 \mathrm{~A}$ & $48 \mathrm{BC}$ & $90 \mathrm{~A}$ & $49 \mathrm{~A}$ & $61 \mathrm{ABC}$ & $61 \mathrm{~B}$ & $60 \mathrm{BC}$ & $49 \mathrm{AB}$ & $66 \mathrm{BC}$ \\
2 & $88 \mathrm{AB}$ & $30 \mathrm{C}$ & $97 \mathrm{~A}$ & $53 \mathrm{~A}$ & $85 \mathrm{~A}$ & $61 \mathrm{~B}$ & $52 \mathrm{BC}$ & $61 \mathrm{AB}$ & $68 \mathrm{BC}$ \\
3 & $93 \mathrm{~A}$ & $64 \mathrm{AB}$ & $91 \mathrm{~A}$ & $28 \mathrm{AB}$ & $77 \mathrm{AB}$ & $42 \mathrm{~B}$ & $37 \mathrm{C}$ & $86 \mathrm{AB}$ & $64 \mathrm{BC}$ \\
4 & $93 \mathrm{~A}$ & $79 \mathrm{~A}$ & $96 \mathrm{~A}$ & $35 \mathrm{AB}$ & $74 \mathrm{AB}$ & $95 \mathrm{~A}$ & $78 \mathrm{AB}$ & $100 \mathrm{~A}$ & $82 \mathrm{~A}$ \\
5 & $92 \mathrm{~A}$ & $48 \mathrm{BC}$ & $89 \mathrm{~A}$ & $19 \mathrm{~B}$ & $47 \mathrm{C}$ & $56 \mathrm{~B}$ & $53 \mathrm{BC}$ & $47 \mathrm{AB}$ & $59 \mathrm{C}$ \\
6 & $83 \mathrm{~B}$ & $46 \mathrm{BC}$ & $93 \mathrm{~A}$ & $53 \mathrm{~A}$ & $57 \mathrm{BC}$ & $96 \mathrm{~A}$ & $100 \mathrm{~A}$ & $10 \mathrm{~B}$ & $75 \mathrm{AB}$ \\
\hline
\end{tabular}

${ }^{\mathrm{a}}$ Means with the same letter in a group of a column are not significantly different at $\alpha=0.05$ (ANOVA).

Table 3.9. BMP compliance for skid trails by attribute.

\begin{tabular}{lccc}
\hline & \multicolumn{2}{c}{ Sites in } & Overall skid trail \\
& Compliance (\%) & Compliance (\%) \\
\hline Attribute & \multicolumn{2}{c}{ Private } & Industry \\
Grade less than 20\% & 77 & 89 & 79 \\
Water bars applied & 54 & 83 & 63 \\
Length smooth & 92 & 84 & 88 \\
Length of berm removed & 45 & 28 & 40 \\
Length outsloped & 71 & 59 & 61 \\
Seed applied & 79 & 93 & 82 \\
Mulch applied & 82 & 58 & 75 \\
Length outside of SMZ & 70 & 95 & 76 \\
\hline
\end{tabular}




\subsubsection{Landing Compliance}

Six BMPs were measured for each landing visited. The distance outside of the SMZ was measured if necessary. The number of trails that had turnouts or diversion ditches used in reclamation were measured. Landings were checked to see if they had been reclaimed properly, which includes the BMPs: smoothness of landing, proper drainage, seed applied, and mulch applied (Table 3.10). These BMPs were checked using "Yes" or "No" questions. The frequencies and percentages are used to display the findings for BMPs on landings.

Table 3.10. Frequencies and percentages of BMPs measured on the landings.

\begin{tabular}{lcccc}
\hline & \multicolumn{2}{c}{ Frequency } & \multicolumn{2}{c}{ Percent } \\
\cline { 2 - 5 } BMP & Yes & No & Yes & No \\
\hline SMZ violation $(\mathrm{Y} / \mathrm{N})$ & 18 & 113 & 14 & 86 \\
Number of trails diverted (\#) & 99 & 32 & 76 & 24 \\
Landing smooth (Y/N) & 115 & 16 & 88 & 12 \\
Landing drained (Y/N) & 125 & 6 & 95 & 5 \\
Landing seeded (Y/N) & 105 & 26 & 80 & 20 \\
Landing mulched $(\mathrm{Y} / \mathrm{N})$ & 101 & 30 & 77 & 23 \\
\hline
\end{tabular}

Significance levels of these six measured variables on the landings were also computed (Table 3.11). There was a significant difference in the number of SMZ violations depending on forester involvement. There were no significant differences among ownerships or harvest methods for the BMPs measured on landings. The significant differences among districts vary with each BMP. District six had the highest number of landings located inside the SMZ, significantly more than other districts $(\mathrm{F}=2.61 ; \mathrm{df}=5,130 ; \mathrm{P}=0.0289)$. District three had the highest number of trails coming into the landing diverted to keep water from running onto the landing with an average of 1.7 trails. District six had the highest number of landings seeded and mulched, while the least number of landings were reclaimed in district three. 
Table 3.11. Means and significance levels of statistics for BMPs measured on landings. ${ }^{a}$

\begin{tabular}{|c|c|c|c|c|c|c|}
\hline & $\begin{array}{c}\text { SMZ } \\
\text { Violation }{ }^{\mathrm{b}} \\
(\mathrm{Y} / \mathrm{N})\end{array}$ & $\begin{array}{l}\text { Trails Diverted } \\
\text { From water } \\
(\#)\end{array}$ & $\begin{array}{c}\text { Landing } \\
\text { Smooth } \\
(\mathrm{Y} / \mathrm{N})\end{array}$ & $\begin{array}{l}\text { Landing } \\
\text { Drained } \\
(\mathrm{Y} / \mathrm{N})\end{array}$ & $\begin{array}{c}\text { Landing } \\
\text { Seeded } \\
(\mathrm{Y} / \mathrm{N})\end{array}$ & $\begin{array}{c}\text { Landing } \\
\text { Mulchec } \\
(\mathrm{Y} / \mathrm{N})\end{array}$ \\
\hline \multicolumn{7}{|c|}{ Forester Involvement } \\
\hline Yes & $0.04 \mathrm{~B}$ & $1.4 \mathrm{~A}$ & $0.8 \mathrm{~A}$ & $0.95 \mathrm{~A}$ & $0.8 \mathrm{~A}$ & $0.77 \mathrm{~A}$ \\
\hline No & $0.18 \mathrm{~A}$ & $1 \mathrm{~A}$ & $0.9 \mathrm{~A}$ & $0.97 \mathrm{~A}$ & $0.8 \mathrm{~A}$ & $0.76 \mathrm{~A}$ \\
\hline \multicolumn{7}{|c|}{ Ownership } \\
\hline Private & $0.1 \mathrm{~A}$ & $1.1 \mathrm{~A}$ & $0.9 \mathrm{~A}$ & $0.94 \mathrm{~A}$ & $0.8 \mathrm{~A}$ & $0.8 \mathrm{~A}$ \\
\hline Industrial & $0.05 \mathrm{~A}$ & $1.4 \mathrm{~A}$ & $0.9 \mathrm{~A}$ & $0.98 \mathrm{~A}$ & $0.7 \mathrm{~A}$ & $0.7 \mathrm{~A}$ \\
\hline \multicolumn{7}{|c|}{ Harvest Method } \\
\hline Clearcut & $0.04 \mathrm{~A}$ & $1.4 \mathrm{~A}$ & $0.9 \mathrm{~A}$ & $0.96 \mathrm{~A}$ & $0.87 \mathrm{~A}$ & $0.83 \mathrm{~A}$ \\
\hline Diameter Limit & $0.15 \mathrm{~A}$ & $1.1 \mathrm{~A}$ & $0.9 \mathrm{~A}$ & $0.95 \mathrm{~A}$ & $0.78 \mathrm{~A}$ & $0.78 \mathrm{~A}$ \\
\hline Selection & $0.06 \mathrm{~A}$ & $1.3 \mathrm{~A}$ & $0.9 \mathrm{~A}$ & $0.96 \mathrm{~A}$ & 0.79A & $0.73 \mathrm{~A}$ \\
\hline \multicolumn{7}{|c|}{ Forest District } \\
\hline 1 & OB & $1.2 \mathrm{AB}$ & $0.8 \mathrm{~A}$ & $0.85 \mathrm{~A}$ & $0.85 \mathrm{AB}$ & $0.85 \mathrm{AB}$ \\
\hline 2 & $0.13 \mathrm{AB}$ & $0.9 \mathrm{AB}$ & $1 \mathrm{~A}$ & $1 \mathrm{~A}$ & $0.75 \mathrm{AB}$ & $0.63 \mathrm{BC}$ \\
\hline 3 & $0.06 \mathrm{~B}$ & $1.7 \mathrm{~A}$ & $0.8 \mathrm{~A}$ & $0.9 \mathrm{~A}$ & $0.62 \mathrm{~B}$ & $0.56 \mathrm{C}$ \\
\hline 4 & 0B & $1.3 \mathrm{AB}$ & $0.8 \mathrm{~A}$ & $1 \mathrm{~A}$ & $0.92 \mathrm{~A}$ & $0.92 \mathrm{~A}$ \\
\hline 5 & $0 \mathrm{~B}$ & $0.9 \mathrm{~B}$ & $0.9 \mathrm{~A}$ & $1 \mathrm{~A}$ & $0.88 \mathrm{AB}$ & $0.88 \mathrm{AB}$ \\
\hline 6 & $0.3 \mathrm{~A}$ & $1.1 \mathrm{AB}$ & $0.95 \mathrm{~A}$ & $1 \mathrm{~A}$ & $1 \mathrm{~A}$ & $1 \mathrm{~A}$ \\
\hline
\end{tabular}

The means and significant differences for percent compliance of BMPs measured on landings are shown in Table 3.12. Forester involvement significantly affected the number of landings that were constructed outside of the SMZ. This is also true for the number of trails that were diverted to keep water from running onto the landings. Industrial owned lands had a compliance level of $95 \%$, which was higher than private lands. District four had the highest compliance for trails diverted from water with 97\%. Landings were smoothed in District two for $100 \%$ of the sampled population. District six had a compliance of $100 \%$ for landings being 
seeded and mulched $(\mathrm{F}=2.66 ; \mathrm{df}=5,115 ; \mathrm{P}=0.0280)$. The overall compliance on landings varied, with the lowest compliance being 75\% in District three and the highest being 91\% in District six. Table 3.12. Means and significance levels of percent compliance for BMPs measured on landings. ${ }^{\mathrm{a}}$

Outside Trails diverted Landing Landing Landing Landing Compliance of SMZ from water smooth drained seeded mulched

\begin{tabular}{|c|c|c|c|c|c|c|c|}
\hline \multicolumn{8}{|c|}{ Forester Involvement } \\
\hline Yes & $97 \mathrm{~A}$ & $84 \mathrm{~A}$ & $81 \mathrm{~A}$ & $91 \mathrm{~A}$ & $79 \mathrm{~A}$ & $75 \mathrm{~A}$ & $85 \mathrm{~A}$ \\
\hline No & 84B & $62 \mathrm{~B}$ & $91 \mathrm{~A}$ & $96 \mathrm{~A}$ & $78 \mathrm{~A}$ & $75 \mathrm{~A}$ & $81 \mathrm{~A}$ \\
\hline \multicolumn{8}{|c|}{ Ownership } \\
\hline Private & $90 \mathrm{~A}$ & $68 \mathrm{~B}$ & $85 \mathrm{~A}$ & $93 \mathrm{~A}$ & $83 \mathrm{~A}$ & $80 \mathrm{~A}$ & $83 \mathrm{~A}$ \\
\hline Industrial & $98 \mathrm{~A}$ & $95 \mathrm{~A}$ & $83 \mathrm{~A}$ & $93 \mathrm{~A}$ & $71 \mathrm{~A}$ & $67 \mathrm{~A}$ & $84 \mathrm{~A}$ \\
\hline \multicolumn{8}{|c|}{ Harvest Method } \\
\hline Clearcut & $96 \mathrm{~A}$ & $91 \mathrm{~A}$ & $87 \mathrm{~A}$ & $91 \mathrm{~A}$ & $83 \mathrm{~A}$ & $78 \mathrm{~A}$ & $88 \mathrm{~A}$ \\
\hline Diameter Limit & $88 \mathrm{~A}$ & $67 \mathrm{~B}$ & $85 \mathrm{~A}$ & $95 \mathrm{~A}$ & $78 \mathrm{~A}$ & $78 \mathrm{~A}$ & $82 \mathrm{~A}$ \\
\hline Selection & $96 \mathrm{~A}$ & 77AB & $82 \mathrm{~A}$ & $92 \mathrm{~A}$ & 77A & $71 \mathrm{~A}$ & $83 \mathrm{~A}$ \\
\hline \multicolumn{8}{|c|}{ Forest District } \\
\hline 1 & $100 \mathrm{~A}$ & $74 \mathrm{ABC}$ & $77 \mathrm{AB}$ & $85 \mathrm{~A}$ & $85 \mathrm{AB}$ & $85 \mathrm{AB}$ & $84 \mathrm{AB}$ \\
\hline 2 & $88 \mathrm{~A}$ & 53C & $100 \mathrm{~A}$ & $100 \mathrm{~A}$ & $75 \mathrm{AB}$ & $63 \mathrm{BC}$ & $80 \mathrm{AB}$ \\
\hline 3 & $94 \mathrm{~A}$ & $90 \mathrm{AB}$ & $72 \mathrm{~B}$ & $85 \mathrm{~A}$ & 59B & $53 \mathrm{C}$ & $75 B$ \\
\hline 4 & $100 \mathrm{~A}$ & $97 \mathrm{~A}$ & $75 \mathrm{AB}$ & $92 \mathrm{~A}$ & $83 \mathrm{AB}$ & $83 \mathrm{AB}$ & $88 \mathrm{AB}$ \\
\hline 5 & $100 \mathrm{~A}$ & $65 \mathrm{BC}$ & $94 \mathrm{AB}$ & $100 \mathrm{~A}$ & $88 \mathrm{AB}$ & $88 \mathrm{AB}$ & $89 \mathrm{AB}$ \\
\hline 6 & $80 \mathrm{~A}$ & $70 \mathrm{ABC}$ & $95 \mathrm{AB}$ & $100 \mathrm{~A}$ & $100 \mathrm{~A}$ & $100 \mathrm{~A}$ & $91 \mathrm{~A}$ \\
\hline
\end{tabular}

BMP compliance on landings presented relatively higher levels on site basis with landings outside of the SMZ being $83 \%$ compliant, approach trails diverted from water were $71 \%$, landings smooth $82 \%$, landings drained $81 \%$, landings seeded $78 \%$, and landings mulched $73 \%$ compliant (Table 3.13). Three of the BMPs had higher compliance levels on private lands, with $88 \%$ for smooth landings, $84 \%$ for landings seeded, and $82 \%$ for landings that were mulched, while other BMPs demonstrated higher compliance on industrial lands. 
Table 3.13. BMP compliance for landings by attribute.

\begin{tabular}{lccc}
\hline & \multicolumn{2}{c}{$\begin{array}{c}\text { Sites in } \\
\text { Compliance (\%) }\end{array}$} & $\begin{array}{c}\text { Overall landing } \\
\text { Compliance (\%) }\end{array}$ \\
\hline Attribute & Private & Industry \\
Landing outside SMZ & 80 & 91 & 83 \\
Approach roads diverted & 69 & 90 & 71 \\
Landing is smooth & 88 & 86 & 82 \\
Landing is drained & 94 & 98 & 81 \\
Landing is seeded & 84 & 73 & 78 \\
Landing is mulched & 82 & 68 & 73 \\
\hline
\end{tabular}

\subsubsection{Streamside Management Zone Compliance}

A total of $51 \mathrm{SMZs}$ were assessed during this study. Ephemeral streams made up 14\% of the streams assessed, then followed intermittent streams that made up 33\%, and perennial streams were 53\%. The average buffer measured for ephemeral streams was 69 feet with a range of 18 to 50 feet (Table 3.14). SMZs for intermittent streams ranged from 0 to 100 feet with an average of 46 feet. Perennial streams had an average buffer width of 48 feet for the SMZ, and ranged from 0 to 100 feet. The average length of skid trail inside of the SMZ was 37 feet, ranging from 0 to 300 feet. The amount of skid trail that was reclaimed in the SMZ ranged from 0 to 150 feet with an average of 59 feet. 
Table 3.14. Statistics of variables measured within SMZs.

\begin{tabular}{lccccc}
\hline BMP & N & Mean & Std. Dev. & Min. & Max. \\
\hline Ephemeral stream width (ft.) & 5 & 69 & 81 & 18 & 50 \\
Intermittent stream width (ft.) & 13 & 46 & 35 & 0 & 100 \\
Perennial stream width (ft.) & 16 & 48 & 25 & 0 & 100 \\
Minimum equipment use (Y/N) & 51 & 0.98 & 0.14 & 0 & 1 \\
SMZ stabilized (Y/N) & 51 & 0.9 & 0.3 & 0 & 1 \\
Landing outside SMZ (Y/N) & 51 & 0.53 & 0.5 & 0 & 1 \\
Landing reclaimed (Y/N) & 51 & 0.9 & 0.3 & 0 & 1 \\
Haul road outside SMZ (Y/N) & 51 & 0.57 & 0.5 & 0 & 1 \\
Haul road reclaimed (Y/N) & 51 & 0.49 & 0.51 & 0 & 1 \\
Skid trail inside SMZ (ft.) & 51 & 37 & 73 & 0 & 300 \\
Skid trail reclaimed (ft.) & 51 & 59 & 49 & 0 & 150 \\
Riprap installed (Y/N) & 51 & 0.68 & 0.47 & 0 & 1 \\
\hline
\end{tabular}

Means and significance levels of the variables measured for SMZs were analyzed (Table 3.15). Forester involvement significantly affected the number of landings reclaimed in the SMZ ( $\mathrm{F}=6.67 ; \mathrm{df}=1,32 ; \mathrm{P}=0.0493)$. The only significant difference among ownership was that haul roads were reclaimed more often on industrial lands $(\mathrm{F}=4.48 ; \mathrm{df}=1,50 ; \mathrm{P}=0.0424)$. Skid trails were constructed inside of the SMZ more often on clearcuts than the other two harvest methods $(\mathrm{F}=5.16 ; \mathrm{df}=2,50 ; \mathrm{P}=0.0102)$. Width of the $\mathrm{SMZ}$ was lowest in districts five and $\operatorname{six}(\mathrm{F}=2.60$; $\mathrm{df}=5,50 ; \mathrm{P}=0.0397)$. District three laid out the largest width for the $\mathrm{SMZ}$, while district four had the least amount of stabilization in the SMZ. District four also had the most landings located outside of the SMZ, but also had the least amount of landings reclaimed on sites where SMZs were found. District two had the most amount of skid trail constructed inside the SMZ and the least amount of skid trail reclaimed. There were no significant differences for the installation of riprap or slope of the SMZs among districts.

There were no significant differences in compliance with SMZ width among the variables tested (Table 3.16). Individual BMP compliance among districts showed some significant 
differences. Compliance for stabilizing the SMZ was only $50 \%$ in district four. Where haul roads were constructed inside of the SMZ, they were reclaimed $75 \%$ of the time in District six. The overall compliance of BMPs measured for SMZs showed no significant differences among districts, ranging from $47 \%$ in District two to $67 \%$ in District five. 
Table 3.15. Means and significance levels of statistics for BMPs measured on SMZs. ${ }^{\text {a }}$

SMZ Minimum SMZ Landing Landing Haul Road Haul Road Skid trail Skid trail Riprap width equipment stabilized out of reclaimed outside Reclaimed inside Reclaimed Installed

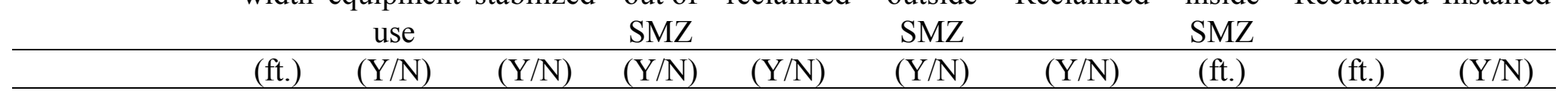

\begin{tabular}{|c|c|c|c|c|c|c|c|c|c|c|}
\hline \multicolumn{11}{|c|}{ Forester Involvement } \\
\hline Yes & $47 \mathrm{~A}$ & $0.96 \mathrm{~A}$ & $0.88 \mathrm{~A}$ & $0.64 \mathrm{~A}$ & $0.88 \mathrm{~A}$ & $0.6 \mathrm{~A}$ & $0.5 \mathrm{~A}$ & $20 \mathrm{~B}$ & $60 \mathrm{~A}$ & $0.8 \mathrm{~A}$ \\
\hline No & $41 \mathrm{~A}$ & $0.9 \mathrm{~A}$ & $0.94 \mathrm{~A}$ & $0.3 \mathrm{~B}$ & $0.94 \mathrm{~A}$ & $0.5 \mathrm{~A}$ & $0.46 \mathrm{~A}$ & $74 \mathrm{~A}$ & $59 \mathrm{~A}$ & $0.4 \mathrm{~B}$ \\
\hline \multicolumn{11}{|c|}{ Ownership } \\
\hline Private & $42 \mathrm{~A}$ & $1 \mathrm{~A}$ & $0.9 \mathrm{~A}$ & $0.5 \mathrm{~A}$ & $0.9 \mathrm{~A}$ & $0.6 \mathrm{~A}$ & $0.4 \mathrm{~B}$ & $39 \mathrm{~A}$ & $60 \mathrm{~A}$ & $0.6 \mathrm{~A}$ \\
\hline Industrial & $52 \mathrm{~A}$ & $0.9 \mathrm{~A}$ & $1 \mathrm{~A}$ & $0.5 \mathrm{~A}$ & $0.9 \mathrm{~A}$ & $0.3 \mathrm{~A}$ & $0.7 \mathrm{~A}$ & $37 \mathrm{~A}$ & $59 \mathrm{~A}$ & $0.9 \mathrm{~A}$ \\
\hline
\end{tabular}

\begin{tabular}{lcccccccccc} 
& \multicolumn{10}{c}{ Harvest Method } \\
Clearcut & $19 \mathrm{~B}$ & $1 \mathrm{~A}$ & $1 \mathrm{~A}$ & $0.3 \mathrm{~A}$ & $1 \mathrm{~A}$ & $0.3 \mathrm{~A}$ & $0.8 \mathrm{~A}$ & $100 \mathrm{~A}$ & $100 \mathrm{~A}$ & $0.5 \mathrm{~A}$ \\
Diameter Limit & $43 \mathrm{AB}$ & $1 \mathrm{~A}$ & $0.9 \mathrm{~A}$ & $0.4 \mathrm{~A}$ & $0.9 \mathrm{~A}$ & $0.5 \mathrm{~A}$ & $0.5 \mathrm{~A}$ & $51 \mathrm{AB}$ & $65 \mathrm{AB}$ & $0.8 \mathrm{~A}$ \\
Selection & $49 \mathrm{~A}$ & $0.9 \mathrm{~A}$ & $0.9 \mathrm{~A}$ & $0.6 \mathrm{~A}$ & $0.9 \mathrm{~A}$ & $0.6 \mathrm{~A}$ & $0.4 \mathrm{~A}$ & $20 \mathrm{~B}$ & $49 \mathrm{~B}$ & $0.6 \mathrm{~A}$
\end{tabular}

\begin{tabular}{lcccccccccc}
\hline \multicolumn{10}{c}{ Forest District } \\
\hline 1 & $46 \mathrm{AB}$ & $0.9 \mathrm{~A}$ & $0.9 \mathrm{~A}$ & $0.7 \mathrm{AB}$ & $0.9 \mathrm{AB}$ & $0.6 \mathrm{~A}$ & $0.6 \mathrm{~A}$ & $28 \mathrm{~A}$ & $64 \mathrm{AB}$ & $0.8 \mathrm{~A}$ \\
2 & $42 \mathrm{AB}$ & $1 \mathrm{~A}$ & $0.9 \mathrm{~A}$ & $0.3 \mathrm{~B}$ & $1 \mathrm{~A}$ & $0.6 \mathrm{~A}$ & $0 \mathrm{~A}$ & $81 \mathrm{~A}$ & $9 \mathrm{~B}$ & $0.4 \mathrm{~A}$ \\
3 & $69 \mathrm{~A}$ & $1 \mathrm{~A}$ & $0.8 \mathrm{AB}$ & $0.7 \mathrm{AB}$ & $0.8 \mathrm{AB}$ & $0.6 \mathrm{~A}$ & $0.3 \mathrm{~A}$ & $33 \mathrm{~A}$ & $53 \mathrm{AB}$ & $0.6 \mathrm{~A}$ \\
4 & $50 \mathrm{AB}$ & $1 \mathrm{~A}$ & $0.5 \mathrm{~B}$ & $1 \mathrm{~A}$ & $0.5 \mathrm{~B}$ & $1 \mathrm{~A}$ & $0.5 \mathrm{~A}$ & $0 \mathrm{~A}$ & $63 \mathrm{AB}$ & $0.5 \mathrm{~A}$ \\
5 & $35 \mathrm{AB}$ & $1 \mathrm{~A}$ & $1 \mathrm{~A}$ & $0.6 \mathrm{AB}$ & $1 \mathrm{~A}$ & $1 \mathrm{~A}$ & $0 \mathrm{~A}$ & $30 \mathrm{~A}$ & $44 \mathrm{AB}$ & $0.8 \mathrm{~A}$ \\
6 & $28 \mathrm{~B}$ & $1 \mathrm{~A}$ & $1 \mathrm{~A}$ & $0.3 \mathrm{~B}$ & $1 \mathrm{~A}$ & $0.3 \mathrm{~A}$ & $0.8 \mathrm{~A}$ & $38 \mathrm{~A}$ & $91 \mathrm{~A}$ & $0.7 \mathrm{~A}$ \\
\hline
\end{tabular}

${ }^{a}$ Means with the same letter in a group of a column are not significantly different at $\alpha=0.05$ (ANOVA). 
Table 3.16. Means and significance levels of percent compliance for BMPs measured within SMZs. ${ }^{\mathrm{a}}$

SMZ Minimum Soil SMZ Haul road Skid trail Landing Riprap Compliance width Equip. disturbed stabilized reclaimed reclaimed reclaimed installed use

\begin{tabular}{|c|c|c|c|c|c|c|c|c|c|}
\hline \multicolumn{10}{|c|}{ Forester Involvement } \\
\hline Yes & $46 \mathrm{~A}$ & $34 \mathrm{~B}$ & $5 \mathrm{~A}$ & $87 \mathrm{~A}$ & $51 \mathrm{~A}$ & $67 \mathrm{~A}$ & $88 \mathrm{~A}$ & $79 \mathrm{~A}$ & $59 \mathrm{~A}$ \\
\hline No & $44 \mathrm{~A}$ & $55 \mathrm{~A}$ & $25 \mathrm{~A}$ & $96 \mathrm{~A}$ & $46 \mathrm{~A}$ & $54 \mathrm{~A}$ & $79 \mathrm{~A}$ & $50 \mathrm{~A}$ & $54 \mathrm{~A}$ \\
\hline \multicolumn{10}{|c|}{ Ownership } \\
\hline Private & $42 \mathrm{~A}$ & $40 \mathrm{~A}$ & $15 \mathrm{~A}$ & $87 \mathrm{~A}$ & $46 \mathrm{~A}$ & $61 \mathrm{~A}$ & $83 \mathrm{~A}$ & $58 \mathrm{~A}$ & $55 \mathrm{~A}$ \\
\hline Industrial & $52 \mathrm{~A}$ & $50 \mathrm{~A}$ & $10 \mathrm{~A}$ & $100 \mathrm{~A}$ & $61 \mathrm{~A}$ & $63 \mathrm{~A}$ & $87 \mathrm{~A}$ & $89 \mathrm{~A}$ & $62 \mathrm{~A}$ \\
\hline \multicolumn{10}{|c|}{ Harvest Method } \\
\hline $\begin{array}{l}\text { Clearcut } \\
\text { Diameter }\end{array}$ & $25 \mathrm{~A}$ & $25 \mathrm{~B}$ & $0 \mathrm{~A}$ & $100 \mathrm{~A}$ & $67 \mathrm{~A}$ & $100 \mathrm{~A}$ & $100 \mathrm{~A}$ & $67 \mathrm{~A}$ & $61 \mathrm{~A}$ \\
\hline Limit & $46 \mathrm{~A}$ & $73 \mathrm{~A}$ & $13 \mathrm{~A}$ & $94 \mathrm{~A}$ & $55 \mathrm{~A}$ & $58 \mathrm{~A}$ & $75 \mathrm{~A}$ & $69 \mathrm{~A}$ & $58 \mathrm{~A}$ \\
\hline Selection & $48 \mathrm{~A}$ & $13 \mathrm{~B}$ & $17 \mathrm{~A}$ & $86 \mathrm{~A}$ & $41 \mathrm{~A}$ & $58 \mathrm{~A}$ & $91 \mathrm{~A}$ & $64 \mathrm{~A}$ & $55 \mathrm{~A}$ \\
\hline \multicolumn{10}{|c|}{ Forest District } \\
\hline 1 & $52 \mathrm{~A}$ & $13 \mathrm{C}$ & $13 \mathrm{~A}$ & $88 \mathrm{~A}$ & $71 \mathrm{~A}$ & $66 \mathrm{~A}$ & $88 \mathrm{~A}$ & $71 \mathrm{~A}$ & $61 \mathrm{~A}$ \\
\hline 2 & $43 \mathrm{~A}$ & $0 \mathrm{C}$ & $42 \mathrm{~A}$ & $92 \mathrm{~A}$ & OB & $25 \mathrm{~A}$ & $100 \mathrm{~A}$ & $50 \mathrm{~A}$ & $47 \mathrm{~A}$ \\
\hline 3 & $65 \mathrm{~A}$ & $0 \mathrm{C}$ & $0 \mathrm{~A}$ & $87 \mathrm{~A}$ & $33 \mathrm{AB}$ & $60 \mathrm{~A}$ & $73 \mathrm{~A}$ & $60 \mathrm{~A}$ & $48 \mathrm{~A}$ \\
\hline 4 & $50 \mathrm{~A}$ & $50 \mathrm{~B}$ & $0 \mathrm{~A}$ & $50 \mathrm{~B}$ & $50 \mathrm{AB}$ & $100 \mathrm{~A}$ & $50 \mathrm{~A}$ & $50 \mathrm{~A}$ & $55 \mathrm{~A}$ \\
\hline 5 & $35 \mathrm{~A}$ & $100 \mathrm{~A}$ & $20 \mathrm{~A}$ & $100 \mathrm{~A}$ & -- & $44 \mathrm{~A}$ & $100 \mathrm{~A}$ & $80 \mathrm{~A}$ & $67 \mathrm{~A}$ \\
\hline 6 & $32 \mathrm{~A}$ & $94 \mathrm{~A}$ & $0 \mathrm{~A}$ & $100 \mathrm{~A}$ & $75 \mathrm{~A}$ & $88 \mathrm{~A}$ & $75 \mathrm{~A}$ & $75 \mathrm{~A}$ & $61 \mathrm{~A}$ \\
\hline
\end{tabular}

${ }^{\mathrm{a}}$ Means with the same letter in a group of a column are not significantly different at $\alpha=0.05$ (ANOVA).

Compliances for the BMPs measured in SMZs were analyzed by site and SMZ (Table 3.17). The major difference in compliance was haul roads being reclaimed when constructed inside of an SMZ. On private lands, the compliance for this BMP was 71\%. The compliance level for installation of riprap, where needed, was the lowest of these BMPs for both ownership types (40\% vs. $50 \%)$. 
Table 3.17. BMP compliance for SMZs by attribute.

\begin{tabular}{lccc}
\hline & \multicolumn{2}{c}{ Sites in } & Overall SMZ \\
& Compliance (\%) & Compliance (\%) \\
\hline Attribute & Private & Industry & \\
Haul road reclaimed & 71 & 92 & 72 \\
Skid trail reclaimed & 79 & 91 & 84 \\
Landing reclaimed & 81 & 93 & 83 \\
Riprap installed & 40 & 50 & 43 \\
\hline
\end{tabular}

\subsubsection{Compliance Summary}

BMP compliance was generally higher with forester involvement (Table 3.18). However, neither forester involvement nor ownership affected BMP compliances significantly. Harvest method did significantly affect the compliances on skid trails and in SMZs.

BMP compliance on haul roads did not differ among districts. The compliance on skid trails showed significant differences among districts, with $95 \%$ in district four and 59\% in district five. The compliance on landings was significantly different between districts, ranging from 52\% to $90 \%$. Compliance in SMZs varied significantly among districts from $48 \%$ in district two to $61 \%$ in district six. Overall tract compliance showed significant differences among districts $(\mathrm{F}=4.01$; $\mathrm{df}=5,115 ; \mathrm{P}=0.0023$ ). District four has the highest compliance level of 93\%, while District three had the lowest level of $67 \%$. 
Table 3.18. Means and significance levels of BMP compliance. ${ }^{a}$

\begin{tabular}{|c|c|c|c|c|c|}
\hline & Haul road & Skid trail & Landing & SMZ & Overall Site \\
\hline \multicolumn{6}{|c|}{ Forester Involvement } \\
\hline Yes & $78 \mathrm{~A}$ & $73 \mathrm{~A}$ & $76 \mathrm{~A}$ & $59 \mathrm{~A}$ & $75 \mathrm{~A}$ \\
\hline No & $73 \mathrm{~A}$ & $70 \mathrm{~A}$ & $72 \mathrm{~A}$ & $62 \mathrm{~A}$ & $72 \mathrm{~A}$ \\
\hline \multicolumn{6}{|c|}{ Ownership } \\
\hline Private & $77 \mathrm{~A}$ & $71 \mathrm{~A}$ & $77 \mathrm{~A}$ & $58 \mathrm{~A}$ & $74 \mathrm{~A}$ \\
\hline Industrial & $75 \mathrm{~A}$ & $74 \mathrm{~A}$ & $71 \mathrm{~A}$ & $67 \mathrm{~A}$ & $74 \mathrm{~A}$ \\
\hline \multicolumn{6}{|c|}{ Harvest Method } \\
\hline Clearcut & $68 \mathrm{~A}$ & $79 \mathrm{~A}$ & $78 \mathrm{~A}$ & $86 \mathrm{~A}$ & $79 \mathrm{~A}$ \\
\hline Diameter Limit & $82 \mathrm{~A}$ & $65 \mathrm{~B}$ & $72 \mathrm{~A}$ & $62 \mathrm{~B}$ & $70 \mathrm{~A}$ \\
\hline Selection & $75 \mathrm{~A}$ & $75 \mathrm{~A}$ & $76 \mathrm{~A}$ & $53 \mathrm{~B}$ & $75 \mathrm{~A}$ \\
\hline \multicolumn{6}{|c|}{ Forest District } \\
\hline 1 & $83 \mathrm{~A}$ & $66 \mathrm{BC}$ & $74 \mathrm{~A}$ & $55 \mathrm{AB}$ & $72 \mathrm{~B}$ \\
\hline 2 & $67 \mathrm{~A}$ & $68 \mathrm{BC}$ & $78 \mathrm{~A}$ & $48 \mathrm{~B}$ & $71 \mathrm{~B}$ \\
\hline 3 & $73 \mathrm{~A}$ & $78 \mathrm{~B}$ & $52 \mathrm{~B}$ & $83 \mathrm{~A}$ & $67 \mathrm{~B}$ \\
\hline 4 & $92 \mathrm{~A}$ & $95 \mathrm{~A}$ & $90 \mathrm{~A}$ & $54 \mathrm{AB}$ & $93 \mathrm{~A}$ \\
\hline 5 & $78 \mathrm{~A}$ & $59 \mathrm{C}$ & $89 \mathrm{~A}$ & $53 \mathrm{AB}$ & $72 \mathrm{~B}$ \\
\hline 6 & $70 \mathrm{~A}$ & $75 \mathrm{~B}$ & $90 \mathrm{~A}$ & $61 \mathrm{AB}$ & $80 \mathrm{~B}$ \\
\hline
\end{tabular}

\subsection{BMP Application and Effectiveness}

\subsubsection{Haul Roads}

The application and effectiveness of BMPs on haul roads were assessed on twenty sites (Table 3.19). The effectiveness variable was lower for the outsloping of cross drainages, and the culverts being cleared to allow water to pass through them easily on haul roads. This can be a major problem resulting in water running across the haul road and creating erosion.

The application and effectiveness of BMPs were examined on the segments of haul roads (Table 3.19). The BMP of grades less than 10\% ranked good in both application and 
effectiveness. Minimum widths of haul roads were applied effectively. The BMP of haul roads constructed outside of SMZs when possible ranked 2.7 for application and 4.7 for effectiveness. Cross drainages had the lowest ranking of 2.2 for application and 3.3 for effectiveness. Haul roads should always be graveled for 200 feet at any public road entrance so as to keep mud off of main roads. Culverts and ditches were checked to see if they were clear of debris. This BMP also had a ranking of fair with a value of 3.6 for effectiveness. Haul roads constructed away from wet areas presented a ranking of 2.9 for application. The average ranking of application of BMPs on haul roads ranged from 2.2 to 3 , which indicates that the BMPs were attempted and most often applied correctly. The average effectiveness levels of the BMPs applied were between 3.3 and 4.9 .

Table 3.19. Statistics of BMP application and effectiveness on haul roads.

\begin{tabular}{|c|c|c|c|c|c|c|c|c|c|}
\hline \multirow[b]{3}{*}{ BMP } & \multirow[b]{3}{*}{$\mathrm{N}$} & \multicolumn{4}{|c|}{ Application } & \multicolumn{4}{|c|}{ Effectiveness } \\
\hline & & & Std. & & & & Std. & & \\
\hline & & Mean & Dev. & Min. & Max. & Mean & Dev. & Min. & Max \\
\hline Less than $10 \%$ grade & 20 & 2.9 & 0.4 & 2 & 3 & 4.5 & 1.3 & 1 & 5 \\
\hline Minimum width of $12 \mathrm{ft}$. & 20 & 2.9 & 0.3 & 2 & 3 & 4.9 & 0.3 & 4 & 5 \\
\hline Constructed out of SMZ & 20 & 2.7 & 0.5 & 2 & 3 & 4.1 & 1.2 & 2 & 5 \\
\hline $\begin{array}{l}\text { Streams crossed at right } \\
\text { angles }\end{array}$ & 10 & 2.4 & 0.8 & 1 & 3 & 4.1 & 1.7 & 1 & 5 \\
\hline $\begin{array}{l}\text { 100ft. Gravel at stream } \\
\text { crossing }\end{array}$ & 11 & 2.6 & 0.8 & 1 & 3 & 4 & 1.6 & 1 & 5 \\
\hline Cross drainage outsloped & 14 & 2.2 & 0.9 & 1 & 3 & 3.3 & 1.9 & 1 & 5 \\
\hline $\begin{array}{l}200 \mathrm{ft} \text {. Gravel at public } \\
\text { road }\end{array}$ & 20 & 3 & 0 & 3 & 3 & 4.9 & 0.2 & 4 & 5 \\
\hline Culverts clear & 11 & 2.6 & 0.8 & 1 & 3 & 3.6 & 1.9 & 1 & 5 \\
\hline Avoid wet areas & 20 & 2.9 & 0.3 & 2 & 3 & 4.5 & 0.9 & 1 & 5 \\
\hline
\end{tabular}

The significance levels for the BMP applications on haul roads were analyzed by forester involvement, ownership, harvest method, and district (Table 3.20). Forester involvement did significantly affect grade $(\mathrm{F}=5.79 ; \mathrm{df}=1,19 ; \mathrm{P}=0.0369)$. A significant difference was also found for grade among the interaction of forester and district. There was also a significant difference in 
the stream crossings and application of gravel in a SMZ $(\mathrm{F}=8.0 ; \mathrm{df}=1,19 ; \mathrm{P}=0.0474)$ between with and without forester involvements. These two fields also had a lower ranking on privately owned lands than on industrial owned lands. Privately owned lands had an application ranking of 2.3 for stream crossings, which was significantly different from industrial land $(\mathrm{F}=39$; $\mathrm{df}=1,19 ; \mathrm{P}=0.0001)$. Harvest method had little effect on these BMPs. Several BMPs were significantly affected by district. However, these BMP applications were not significantly different among districts.

With no forester involved the field for assessing grade had an effectiveness level of 4.1 out of 5, which was significantly lower than with forester involvement $(F=65.33 ; \mathrm{df}=1,19$; $\mathrm{P}=0.0014$ ) (Table 3.21). On privately owned lands where haul roads were constructed inside the SMZ the effectiveness ranking for streams being crossed at right angles was 3.7, which was significantly lower than on industrial owned lands $(\mathrm{F}=64 ; \mathrm{df}=1,19 ; \mathrm{P}=0.0013)$. The sites with diameter limit cuts presented lower effectiveness rankings for grade, being constructed outside the SMZ, stream crossings at right angles, and gravel applied to stream crossings compared to the other two harvest methods. The lowest effectiveness ranking for grade in District five differed significantly from other districts $(\mathrm{F}=24.16 ; \mathrm{df}=5,19 ; \mathrm{P}=0.0001)$. The lower effectiveness ranking for right angle stream crossings $(\mathrm{F}=65.33 ; \mathrm{df}=1,19 ; \mathrm{P}=0.0013)$ and gravel applied at stream crossings $(\mathrm{F}=10.99 ; \mathrm{df}=2,19 ; \mathrm{P}=0.0237)$ in District four were also significantly different from the other districts. District four also had a significantly lower effectiveness ranking for the haul roads being constructed outside of wet areas. 
Table 3.20. Means and significance levels of BMP applications on haul roads. ${ }^{\text {a }}$

\begin{tabular}{|c|c|c|c|c|c|c|c|c|c|}
\hline & $\begin{array}{c}\text { Grade less } \\
\text { than } \\
10 \% \\
\end{array}$ & $\begin{array}{l}\text { Minimum } \\
\text { width } \\
12 \mathrm{ft} . \\
\end{array}$ & $\begin{array}{c}\text { Haul road } \\
\text { out of } \\
\text { SMZ } \\
\end{array}$ & $\begin{array}{c}\text { Stream } \\
\text { crossing right } A \\
\text { angle } \\
\end{array}$ & $\begin{array}{c}\text { Gravel } \\
\text { Applied } 100 \mathrm{ft} \\
\text { from SMZ } \\
\end{array}$ & $\begin{array}{c}\text { Cross } \\
\text { drainage } \\
\text { outsloped } \\
\end{array}$ & $\begin{array}{c}\text { Gravel } \\
200 \mathrm{ft} \text {. from } \\
\text { public road }\end{array}$ & $\begin{array}{c}\text { Culvert/Ditch } \\
\text { Clear }\end{array}$ & $\begin{array}{c}\text { Avoid } \\
\text { Wet } \\
\text { Areas } \\
\end{array}$ \\
\hline \multicolumn{10}{|c|}{ Forester Involvement } \\
\hline$\overline{\text { Yes }}$ & $2.8 \mathrm{~A}$ & $3 \mathrm{~A}$ & $2.5 \mathrm{~A}$ & $2 \mathrm{~B}$ & $2 \mathrm{~B}$ & $2.6 \mathrm{~A}$ & $3 \mathrm{~A}$ & $2.6 \mathrm{~A}$ & $2.8 \mathrm{~A}$ \\
\hline No & $2.75 \mathrm{~B}$ & $2.88 \mathrm{~B}$ & $2.6 \mathrm{~A}$ & $3 \mathrm{~A}$ & $3 \mathrm{~A}$ & $1.9 \mathrm{~A}$ & $3 \mathrm{~A}$ & $2.5 \mathrm{~A}$ & $2.7 \mathrm{~A}$ \\
\hline \multicolumn{10}{|c|}{ Ownership } \\
\hline Private & $2.8 \mathrm{~A}$ & $2.9 \mathrm{~B}$ & $2.5 \mathrm{~A}$ & $2.3 \mathrm{~B}$ & $2.4 \mathrm{~B}$ & $2.2 \mathrm{~A}$ & $3 \mathrm{~A}$ & $2.4 \mathrm{~A}$ & $2.9 \mathrm{~A}$ \\
\hline Industrial & $2.9 \mathrm{~A}$ & $3 \mathrm{~A}$ & 2.9A & $2.9 \mathrm{~A}$ & $2.9 \mathrm{~A}$ & $2 \mathrm{~A}$ & $3 \mathrm{~A}$ & $3 \mathrm{~A}$ & $2.9 \mathrm{~A}$ \\
\hline \multicolumn{10}{|c|}{ Harvest Method } \\
\hline $\begin{array}{l}\text { Clearcut } \\
\text { Diameter }\end{array}$ & $3 \mathrm{~A}$ & $3 \mathrm{~A}$ & $3 \mathrm{~A}$ & $3 \mathrm{~A}$ & $3 \mathrm{~A}$ & $2 \mathrm{~A}$ & $3 \mathrm{~A}$ & $3 \mathrm{~A}$ & $3 \mathrm{~A}$ \\
\hline Limit & $2.6 \mathrm{~B}$ & $3 \mathrm{~A}$ & $2.4 \mathrm{~A}$ & $1 \mathrm{C}$ & $1 \mathrm{~B}$ & $2.5 \mathrm{~A}$ & $3 \mathrm{~A}$ & $2.3 \mathrm{~A}$ & $2.8 \mathrm{~A}$ \\
\hline Selection & $2.9 \mathrm{~A}$ & $2.9 \mathrm{~A}$ & $2.7 \mathrm{~A}$ & $2.5 \mathrm{~B}$ & $2.6 \mathrm{~A}$ & $2.1 \mathrm{~A}$ & $3 \mathrm{~A}$ & $2.7 \mathrm{~A}$ & $2.9 \mathrm{~A}$ \\
\hline \multicolumn{10}{|c|}{ Forest District } \\
\hline 1 & $3 \mathrm{~A}$ & $2.8 \mathrm{~A}$ & $2.8 \mathrm{AB}$ & $2 \mathrm{C}$ & $2.5 \mathrm{~A}$ & $2.5 \mathrm{~A}$ & $3 \mathrm{~A}$ & $3 \mathrm{~A}$ & $2.8 \mathrm{~A}$ \\
\hline 2 & $3 \mathrm{~A}$ & $3 \mathrm{~A}$ & $2.3 \mathrm{AB}$ & $3 \mathrm{~A}$ & $3 \mathrm{~A}$ & $1.7 \mathrm{~A}$ & $3 \mathrm{~A}$ & $3 \mathrm{~A}$ & $3 \mathrm{~A}$ \\
\hline 3 & $3 \mathrm{~A}$ & $3 \mathrm{~A}$ & $3 \mathrm{~A}$ & $2.3 \mathrm{~B}$ & $2.5 \mathrm{~A}$ & $2.5 \mathrm{~A}$ & $3 \mathrm{~A}$ & $2.5 \mathrm{~A}$ & $3 \mathrm{~A}$ \\
\hline 4 & $2.5 \mathrm{~B}$ & $3 \mathrm{~A}$ & $2.5 \mathrm{AB}$ & $1 \mathrm{D}$ & $1 \mathrm{~B}$ & $2 \mathrm{~A}$ & $3 \mathrm{~A}$ & $2 \mathrm{~A}$ & $2.5 \mathrm{~A}$ \\
\hline 5 & $2 \mathrm{C}$ & $3 \mathrm{~A}$ & $2 \mathrm{~B}$ & -- & -- & $3 \mathrm{~A}$ & $3 \mathrm{~A}$ & -- & $3 \mathrm{~A}$ \\
\hline 6 & $2.7 \mathrm{AB}$ & $2.7 \mathrm{~A}$ & 2.7AB & -- & -- & $2 \mathrm{~A}$ & $3 \mathrm{~A}$ & $3 \mathrm{~A}$ & $3 \mathrm{~A}$ \\
\hline
\end{tabular}

\footnotetext{
${ }^{\mathrm{a}}$ Means with the same letter in a group of a column are not significantly different at $\alpha=0.05$ (ANOVA).
} 
Table 3.21. Means and significance levels of BMP effectiveness on haul roads. ${ }^{\text {a }}$

\begin{tabular}{|c|c|c|c|c|c|c|c|c|c|}
\hline & $\begin{array}{c}\text { Grade less } \\
\text { than } \\
10 \%\end{array}$ & $\begin{array}{l}\text { Minimum } \\
\text { width } \\
12 \mathrm{ft} .\end{array}$ & $\begin{array}{c}\text { Haul road } \\
\text { out of } \\
\text { SMZ }\end{array}$ & $\begin{array}{c}\text { Stream } \\
\text { crossing right } \\
\text { angle }\end{array}$ & $\begin{array}{c}\text { Gravel } \\
\text { Applied } 100 \mathrm{ft} . \\
\text { from SMZ }\end{array}$ & $\begin{array}{c}\text { Cross } \\
\text { drainage } \\
\text { outsloped }\end{array}$ & $\begin{array}{c}\text { Gravel } \\
200 \mathrm{ft} \text {. from } \\
\text { public road }\end{array}$ & $\begin{array}{l}\text { Culvert/ditch } \\
\text { clear }\end{array}$ & $\begin{array}{l}\text { Avoid } \\
\text { Wet } \\
\text { Areas }\end{array}$ \\
\hline \multicolumn{10}{|c|}{ Forester Involvement } \\
\hline Yes & $4.3 \mathrm{~S}$ & $5 \mathrm{~A}$ & $3.7 \mathrm{~A}$ & $3 \mathrm{~B}$ & $3 \mathrm{~B}$ & $3.6 \mathrm{~A}$ & $5 \mathrm{~A}$ & $2.8 \mathrm{~A}$ & $4.2 \mathrm{~A}$ \\
\hline No & 4.1B & $4.9 \mathrm{~B}$ & $3.8 \mathrm{~A}$ & $5 \mathrm{~A}$ & $4.6 \mathrm{~A}$ & $2.7 \mathrm{~A}$ & $4.9 \mathrm{~A}$ & $4 \mathrm{~A}$ & $4.6 \mathrm{~A}$ \\
\hline \multicolumn{10}{|c|}{ Ownership } \\
\hline Private & $4.1 \mathrm{~A}$ & $4.9 \mathrm{~B}$ & $3.9 \mathrm{~B}$ & $3.7 \mathrm{~B}$ & $3.8 \mathrm{~A}$ & $3.1 \mathrm{~A}$ & $5 \mathrm{~A}$ & $3.3 \mathrm{~A}$ & $4.3 \mathrm{~A}$ \\
\hline Industrial & $4.4 \mathrm{~A}$ & $5 \mathrm{~A}$ & $4.8 \mathrm{~A}$ & $4.8 \mathrm{~A}$ & $4.8 \mathrm{~A}$ & $3 \mathrm{~A}$ & $4.9 \mathrm{~A}$ & $3.5 \mathrm{~A}$ & $4.8 \mathrm{~A}$ \\
\hline \multicolumn{10}{|c|}{ Harvest Method } \\
\hline $\begin{array}{l}\text { Clearcut } \\
\text { Diameter }\end{array}$ & $5 \mathrm{~A}$ & $5 \mathrm{~A}$ & $5 \mathrm{~A}$ & $5 \mathrm{~A}$ & $5 \mathrm{~A}$ & $3 \mathrm{~A}$ & $5 \mathrm{~A}$ & $3.5 \mathrm{~A}$ & $5 \mathrm{~A}$ \\
\hline Limit & $3.8 \mathrm{~B}$ & $5 \mathrm{~A}$ & $3.2 \mathrm{~B}$ & $1 \mathrm{~B}$ & $1 \mathrm{~B}$ & $3.3 \mathrm{~A}$ & $5 \mathrm{~A}$ & $2.3 \mathrm{~A}$ & $3.8 \mathrm{~A}$ \\
\hline Selection & $4.6 \mathrm{~A}$ & $4.9 \mathrm{~A}$ & $4.3 \mathrm{~A}$ & $4.4 \mathrm{~A}$ & $4 \mathrm{~A}$ & $3.4 \mathrm{~A}$ & $4.9 \mathrm{~A}$ & $4.3 \mathrm{~A}$ & $4.8 \mathrm{~A}$ \\
\hline \multicolumn{10}{|c|}{ Forest District } \\
\hline 1 & $5 \mathrm{~A}$ & $4.8 \mathrm{~A}$ & $5 \mathrm{~A}$ & $4.5 \mathrm{AB}$ & $4.5 \mathrm{~A}$ & $4.5 \mathrm{~A}$ & $5 \mathrm{~A}$ & $5 \mathrm{~A}$ & $4.8 \mathrm{~A}$ \\
\hline 2 & $4.8 \mathrm{AB}$ & $5 \mathrm{~A}$ & $3 B$ & $5 \mathrm{~A}$ & $4.5 \mathrm{~A}$ & $2.3 \mathrm{~A}$ & $4.8 \mathrm{~A}$ & $5 \mathrm{~A}$ & $4.5 \mathrm{AB}$ \\
\hline 3 & $5 \mathrm{~A}$ & $5 \mathrm{~A}$ & $5 \mathrm{~A}$ & $3.7 \mathrm{~B}$ & $4 \mathrm{~A}$ & $4 \mathrm{~A}$ & $5 \mathrm{~A}$ & $3.3 \mathrm{~A}$ & $5 \mathrm{~A}$ \\
\hline 4 & $4 \mathrm{BC}$ & $5 \mathrm{~A}$ & $3.5 \mathrm{~B}$ & $1 \mathrm{C}$ & $1 \mathrm{~B}$ & $1.5 \mathrm{~A}$ & $5 \mathrm{~A}$ & $1 \mathrm{~A}$ & $3 B$ \\
\hline 5 & $1 \mathrm{D}$ & $5 \mathrm{~A}$ & $3 \mathrm{~B}$ & -- & -- & $5 \mathrm{~A}$ & $5 \mathrm{~A}$ & -- & $5 \mathrm{~A}$ \\
\hline 6 & $3.7 \mathrm{C}$ & $4.7 \mathrm{~A}$ & $3.3 \mathrm{~B}$ & -- & -- & $3 \mathrm{~A}$ & $5 \mathrm{~A}$ & $5 \mathrm{~A}$ & $4.3 \mathrm{AB}$ \\
\hline
\end{tabular}




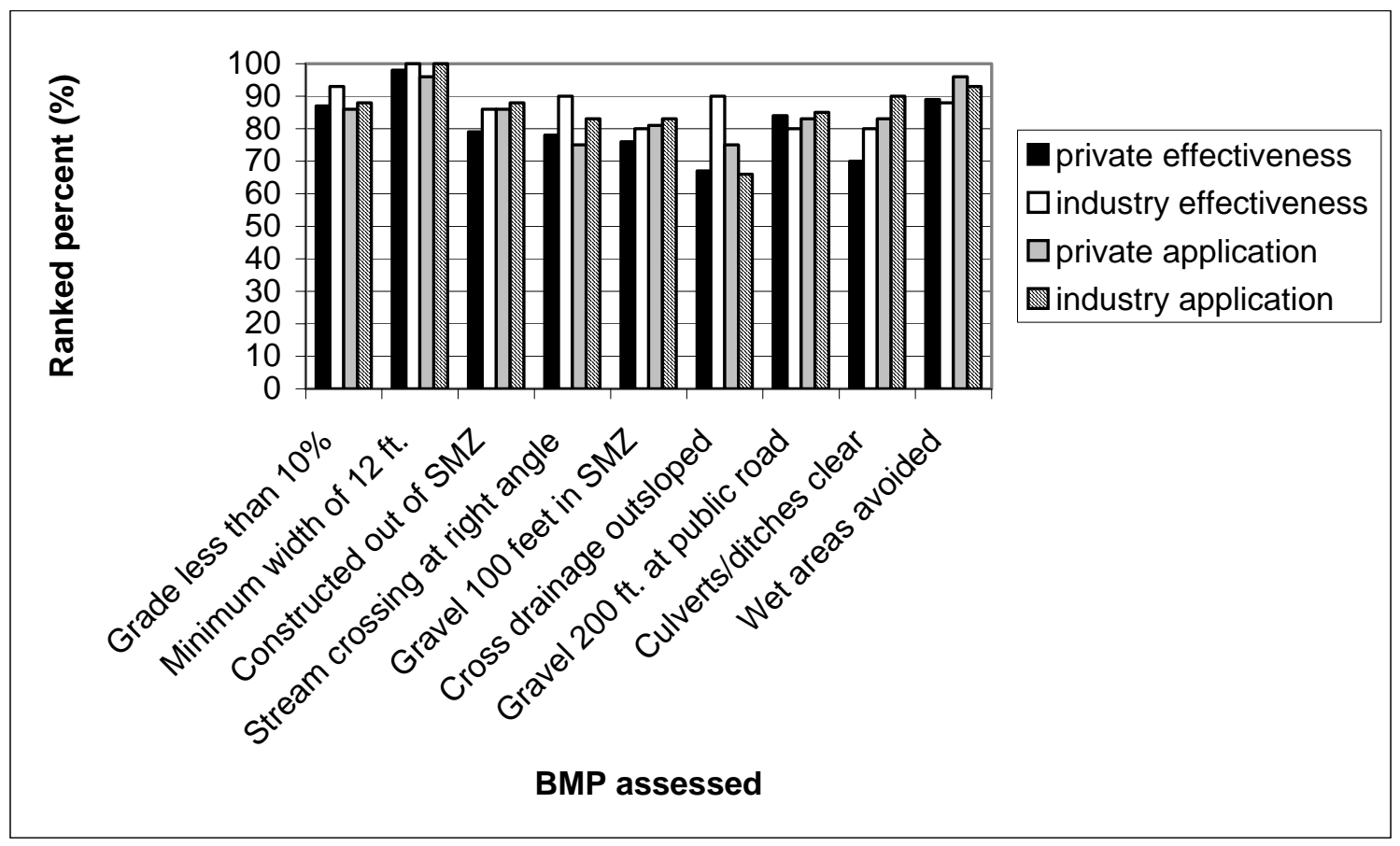

Figure 3.1. Haul road application and effectiveness ranking percentage by ownership.

There were slight differences between the ranking percentages for the BMPs among ownerships. Private haul roads had steeper grades, which gave them a lower ranking for the BMP. The effectiveness on private lands ranked consistently less than on industry land. Effectiveness of industry constructed cross drainages ranked higher (90\%) than privately owned lands. Applications of the BMPs were found to be consistent with each other for both ownership types. However, the effectiveness of those applied BMPs did show variation (Figure 3.1).

\subsubsection{Skid Trails}

Skid trail grades of less than $15 \%$ were applied and effectively implemented on all trails (Table 3.22). Steeper grades are allowed for short distances and should also be constructed outside of SMZs whenever possible. Cross drainages are recommended every 100 feet, but this 
distance shortens with an increase in grade. This BMP had only a fair level of effectiveness. The water bars had an effectiveness level of fair. The effectiveness ranking for the spacing and construction of water bars was 3.4. The application of culverts or bridges used to cross streams were also assessed for effectiveness. If no culvert or bridge was used or necessary then streams should be crossed at right angles. There should be no skidding directly up or down a stream channel. Skid trails should be spaced about 200 feet apart on the harvest. The trails should also be stabilized after the harvest is complete to reduce runoff and slips. The application rankings for the skid trail BMPs were 2.4 to 2.9, which indicates the skid trails were applied properly. The effectiveness of BMPs on skid trails ranged from 3.4 to 4.9 and simply meant a ranking of fair to good.

Table 3.22. Statistics of BMPs on skid trails for application and effectiveness.

\begin{tabular}{lccccccccc}
\hline BMP & \multicolumn{4}{c}{ Application } & \multicolumn{5}{c}{ Effectiveness } \\
\hline & $\mathrm{N}$ & \multicolumn{1}{c}{ Mean Std. Dev. Min. Max. Mean Std. Dev. Min. Max. } \\
\hline Grade less than 15\% & 33 & 2.9 & 0.3 & 2 & 3 & 4.5 & 0.8 & 2 & 5 \\
$\begin{array}{l}\text { Distance from SMZ } \\
\text { At least 25 ft. from ephemeral }\end{array}$ & 33 & 2.8 & 0.4 & 2 & 3 & 3.9 & 0.9 & 2 & 5 \\
streams & 31 & 2.8 & 0.3 & 2 & 3 & 4.2 & 0.9 & 2 & 5 \\
$\begin{array}{l}\text { Presence of cross drainages } \\
\text { Presence and construction of }\end{array}$ & 33 & 2.5 & 0.7 & 1 & 3 & 3.4 & 1.3 & 1 & 5 \\
water bars & 33 & 2.4 & 0.7 & 1 & 3 & 3.4 & 1.5 & 1 & 5 \\
Culvert/bridge used where & & & & & & & & & \\
needed & 23 & 2.6 & 0.7 & 1 & 3 & 3.9 & 1.6 & 1 & 5 \\
Streams crossed at right angles & 28 & 2.8 & 0.6 & 1 & 3 & 4.4 & 1.1 & 1 & 5 \\
No skidding in streams & 33 & 2.9 & 0.2 & 2 & 3 & 4.9 & 0.6 & 2 & 5 \\
Trail spacing of 200 ft. & 33 & 2.9 & 0.4 & 1 & 3 & 4.8 & 0.7 & 2 & 5 \\
Trail banks stabilized & 33 & 2.9 & 0.3 & 2 & 3 & 4.6 & 0.9 & 2 & 5 \\
\hline
\end{tabular}

The applications for water bar spacing $(\mathrm{F}=0.56 ; \mathrm{df}=1,32 ; \mathrm{P}=0.0030)$ and water bar construction $(\mathrm{F}=0.14 ; \mathrm{df}=1,32 ; \mathrm{P}=0.0106)$ were significantly lower without forester involvement than with forester involvement (Table 3.23). These two BMPs had significantly lower rankings on privately owned land as opposed to industrial owned land. Clearcut sites had a significantly lower 
ranking for application of proper trail spacing with a ranking of 2 , and was significantly different from the other two methods $(\mathrm{F}=3.27 ; \mathrm{df}=2,32 ; \mathrm{P}=0.0061)$. The application among districts varied slightly. District two had significantly lower application levels for water bar spacing $(\mathrm{F}=2.12$; $\mathrm{df}=5,32 ; \mathrm{P}=0.0099)$ and also construction of water bars $(\mathrm{F}=3.47 ; \mathrm{df}=5,32 ; \mathrm{P}=0.0176)$ compared to the other districts. District four was the only district where skidding was found to be done in a stream. This gave district four an application ranking of 2.5 for this $\mathrm{BMP}(\mathrm{F}=4.01 ; \mathrm{df}=5,32$; $\mathrm{P}=0.0092$ ). A significant difference was also found for the application and effectiveness levels of no skidding in streams among the interactions of forester and district.

The forester involvement also affected the effectiveness of the cross drainage spacing and construction of water bars was also lower with no forester involvement (Table 3.24). Trail spacing on clearcut sites received a ranking of $4(\mathrm{~F}=2.49 ; \mathrm{df}=2,32 ; \mathrm{P}=0.0103)$, which was significantly lower than the other two harvest methods. The effectiveness ranking for construction of water bars in district two was 2 , which was significantly lower than the other districts ( $\mathrm{F}=5.09$; $\mathrm{df}=5,32 ; \mathrm{P}=0.0028)$. District four also had a significantly lower ranking for skidding in streams with a 3.5 that significantly differed from the other districts $(\mathrm{F}=3.21 ; \mathrm{df}=5,32 ; \mathrm{P}=0.0243)$. 
Table 3.23. Means and significance levels of BMP applications on skid trails. ${ }^{\text {a }}$

Grade Out Correct Cross Construction Culvert/bridge Stream No skidding Trails Stabilization less than of distance drainages of Used crossed at in spaced of trail $15 \%$ SMZ from streams every $100 \mathrm{ft}$. Water bars $\quad$ right angle $\quad$ streams $200 \mathrm{ft}$.

Forester Involvement

\begin{tabular}{lllllllllll}
\hline Yes & $2.9 \mathrm{~A}$ & $2.7 \mathrm{~A}$ & $2.8 \mathrm{~A}$ & $2.6 \mathrm{~A}$ & $2.6 \mathrm{~A}$ & $2.7 \mathrm{~A}$ & $2.8 \mathrm{~A}$ & $2.9 \mathrm{~A}$ & $2.8 \mathrm{~A}$ & $2.8 \mathrm{~A}$ \\
No & $2.7 \mathrm{~A}$ & $2.9 \mathrm{~A}$ & $2.9 \mathrm{~A}$ & $2.2 \mathrm{~B}$ & $2.1 \mathrm{~B}$ & $2.4 \mathrm{~A}$ & $2.7 \mathrm{~A}$ & $3 \mathrm{~A}$ & $3 \mathrm{~A}$ & $2.9 \mathrm{~A}$
\end{tabular}

\begin{tabular}{lcccccccccc}
\multicolumn{10}{c}{ Ownership } \\
\hline Private & $2.8 \mathrm{~A}$ & $2.8 \mathrm{~A}$ & $2.8 \mathrm{~A}$ & $2.3 \mathrm{~B}$ & $2.3 \mathrm{~B}$ & $2.5 \mathrm{~A}$ & $2.8 \mathrm{~A}$ & $3 \mathrm{~A}$ & $2.9 \mathrm{~A}$ & $2.8 \mathrm{~A}$ \\
Industrial & $2.9 \mathrm{~A}$ & $2.9 \mathrm{~A}$ & $3 \mathrm{~A}$ & $2.9 \mathrm{~A}$ & $2.9 \mathrm{~A}$ & $2.8 \mathrm{~A}$ & $2.8 \mathrm{~A}$ & $3 \mathrm{~A}$ & $2.8 \mathrm{~A}$ & $3 \mathrm{~A}$
\end{tabular}

\begin{tabular}{lccccccccccc}
\multicolumn{10}{c}{ Harvest Method } \\
\hline $\begin{array}{l}\text { Clearcut } \\
\text { Diameter }\end{array}$ & $2.9 \mathrm{~A}$ & $3 \mathrm{~A}$ & $3 \mathrm{~A}$ & $2.7 \mathrm{~A}$ & $2.7 \mathrm{~A}$ & $3 \mathrm{~A}$ & $2.3 \mathrm{~A}$ & $3 \mathrm{~A}$ & $2.3 \mathrm{~B}$ & $3 \mathrm{~A}$ \\
Limit & $2.8 \mathrm{~A}$ & $2.8 \mathrm{~A}$ & $2.9 \mathrm{~A}$ & $2.6 \mathrm{~A}$ & $2.6 \mathrm{~A}$ & $2.7 \mathrm{~A}$ & $2.9 \mathrm{~A}$ & $2.9 \mathrm{~A}$ & $3 \mathrm{~A}$ & $2.9 \mathrm{~A}$ \\
Selection & $2.9 \mathrm{~A}$ & $2.8 \mathrm{~A}$ & $2.8 \mathrm{~A}$ & $2.3 \mathrm{~A}$ & $2.3 \mathrm{~A}$ & $2.4 \mathrm{~A}$ & $2.8 \mathrm{~A}$ & $3 \mathrm{~A}$ & $3 \mathrm{~A}$ & $2.9 \mathrm{~A}$
\end{tabular}

\begin{tabular}{|c|c|c|c|c|c|c|c|c|c|c|}
\hline \multicolumn{11}{|c|}{ Forest District } \\
\hline 1 & $2.9 \mathrm{~A}$ & $2.9 \mathrm{~A}$ & $3 \mathrm{~A}$ & $2.6 \mathrm{ABC}$ & $2.7 \mathrm{AB}$ & $2.8 \mathrm{~A}$ & $3 \mathrm{~A}$ & $3 \mathrm{~A}$ & $2.9 \mathrm{~A}$ & $2.9 \mathrm{~A}$ \\
\hline 2 & $2.9 \mathrm{~A}$ & $2.7 \mathrm{~A}$ & $2.7 \mathrm{~A}$ & $1.8 \mathrm{C}$ & $1.7 \mathrm{C}$ & $2 \mathrm{~A}$ & $2.7 \mathrm{~A}$ & $3 \mathrm{~A}$ & $3 \mathrm{~A}$ & $3 \mathrm{~A}$ \\
\hline 3 & $2.7 \mathrm{~A}$ & $2.8 \mathrm{~A}$ & $2.8 \mathrm{~A}$ & $3 \mathrm{~A}$ & $3 \mathrm{~A}$ & $3 \mathrm{~A}$ & $2.4 \mathrm{~A}$ & $3 \mathrm{~A}$ & $2.6 \mathrm{~A}$ & $2.8 \mathrm{~A}$ \\
\hline 4 & $3 \mathrm{~A}$ & $3 \mathrm{~A}$ & $3 \mathrm{~A}$ & $3 \mathrm{~A}$ & $3 \mathrm{~A}$ & $2 \mathrm{~A}$ & $3 \mathrm{~A}$ & $2.5 \mathrm{~B}$ & $3 \mathrm{~A}$ & $2.5 \mathrm{~A}$ \\
\hline 5 & $2.8 \mathrm{~A}$ & $2.8 \mathrm{~A}$ & $3 \mathrm{~A}$ & $2.8 \mathrm{AB}$ & $2.8 \mathrm{~A}$ & $2.6 \mathrm{~A}$ & $3 \mathrm{~A}$ & $3 \mathrm{~A}$ & $3 \mathrm{~A}$ & $3 \mathrm{~A}$ \\
\hline 6 & $2.8 \mathrm{~A}$ & $2.8 \mathrm{~A}$ & $2.8 \mathrm{~A}$ & $2.1 \mathrm{BC}$ & $2 \mathrm{BC}$ & $2.4 \mathrm{~A}$ & $2.7 \mathrm{~A}$ & $3 \mathrm{~A}$ & $3 \mathrm{~A}$ & $2.9 \mathrm{~A}$ \\
\hline
\end{tabular}

\footnotetext{
${ }^{a}$ Means with the same letter in a group of a column are not significantly different at $\alpha=0.05$ (ANOVA).
} 
Table 3.24. Means and significance levels of BMP effectiveness on skid trails. ${ }^{a}$

\begin{tabular}{|c|c|c|c|c|c|c|c|c|c|c|}
\hline & $\begin{array}{c}\text { Grade } \\
\text { less than } \\
15 \% \\
\end{array}$ & $\begin{array}{c}\text { Out } \\
\text { of } \\
\text { SMZ } \\
\end{array}$ & $\begin{array}{c}\text { Correct } \\
\text { distance } \\
\text { from streams }\end{array}$ & $\begin{array}{c}\text { Cross } \\
\text { drainages } \\
\text { every } 100 \mathrm{ft} .\end{array}$ & $\begin{array}{c}\text { Construction } \\
\text { of } \\
\text { Water bars } \\
\end{array}$ & $\begin{array}{c}\text { Culvert/bridge } \\
\text { Used }\end{array}$ & $\begin{array}{c}\text { Stream } \\
\text { crossed at } \\
\text { right angle } \\
\end{array}$ & $\begin{array}{c}\text { No skidding } \\
\text { in } \\
\text { streams } \\
\end{array}$ & $\begin{array}{l}\text { Trails } \\
\text { spaced } \\
200 \mathrm{ft} . \\
\end{array}$ & $\begin{array}{c}\text { Stabilization } \\
\text { of trail }\end{array}$ \\
\hline \multicolumn{11}{|c|}{ Forester Involvement } \\
\hline Yes & $4.5 \mathrm{~A}$ & $3.8 \mathrm{~A}$ & $4 \mathrm{~A}$ & $3.7 \mathrm{~A}$ & $3.8 \mathrm{~A}$ & $4 \mathrm{~A}$ & $4.4 \mathrm{~A}$ & $4.8 \mathrm{~A}$ & $4.6 \mathrm{~A}$ & $4.4 \mathrm{~A}$ \\
\hline No & $4.6 \mathrm{~A}$ & $4.1 \mathrm{~A}$ & $4.5 \mathrm{~A}$ & $2.9 \mathrm{~B}$ & $2.9 \mathrm{~B}$ & $3.8 \mathrm{~A}$ & $4.5 \mathrm{~A}$ & $5 \mathrm{~A}$ & $5 \mathrm{~A}$ & $4.8 \mathrm{~A}$ \\
\hline \multicolumn{11}{|c|}{ Ownership } \\
\hline Private & $4.6 \mathrm{~A}$ & $3.8 \mathrm{~A}$ & $4.1 \mathrm{~A}$ & $3.2 \mathrm{~A}$ & $3.2 \mathrm{~B}$ & $3.8 \mathrm{~A}$ & $4.4 \mathrm{~A}$ & $4.9 \mathrm{~A}$ & $4.8 \mathrm{~A}$ & $4.5 \mathrm{~A}$ \\
\hline Industrial & $4.4 \mathrm{~A}$ & $4.3 \mathrm{~A}$ & $4.6 \mathrm{~A}$ & $3.9 \mathrm{~A}$ & $4.1 \mathrm{~A}$ & $4.3 \mathrm{~A}$ & $4.5 \mathrm{~A}$ & $4.9 \mathrm{~A}$ & $4.6 \mathrm{~A}$ & $4.8 \mathrm{~A}$ \\
\hline \multicolumn{11}{|c|}{ Harvest Method } \\
\hline $\begin{array}{l}\text { Clearcut } \\
\text { Diameter }\end{array}$ & $5 \mathrm{~A}$ & $4.7 \mathrm{~A}$ & $4.7 \mathrm{~A}$ & $4 \mathrm{~A}$ & $4.3 \mathrm{~A}$ & $5 \mathrm{~A}$ & $4 \mathrm{~A}$ & $5 \mathrm{~A}$ & $4 \mathrm{~B}$ & $4.3 \mathrm{~A}$ \\
\hline Limit & $4.3 \mathrm{~A}$ & $3.9 \mathrm{~A}$ & $4.3 \mathrm{~A}$ & $3.3 \mathrm{~A}$ & $3.3 \mathrm{~A}$ & $3.8 \mathrm{~A}$ & $4.2 \mathrm{~A}$ & $4.7 \mathrm{~A}$ & $4.9 \mathrm{~A}$ & $4.6 \mathrm{~A}$ \\
\hline Selection & $4.6 \mathrm{~A}$ & $3.8 \mathrm{~A}$ & $4 \mathrm{~A}$ & $3.4 \mathrm{~A}$ & $3.4 \mathrm{~A}$ & $4 \mathrm{~A}$ & $4.7 \mathrm{~A}$ & $5 \mathrm{~A}$ & $4.8 \mathrm{~A}$ & $4.6 \mathrm{~A}$ \\
\hline \multicolumn{11}{|c|}{ Forest District } \\
\hline 1 & $4.7 \mathrm{~A}$ & $4 \mathrm{~A}$ & $4.3 \mathrm{~A}$ & $4.1 \mathrm{~A}$ & $4.4 \mathrm{~A}$ & $4.5 \mathrm{~A}$ & $5 \mathrm{~A}$ & $5 \mathrm{~A}$ & $4.6 \mathrm{~A}$ & $4.6 \mathrm{AB}$ \\
\hline 2 & $4.8 \mathrm{~A}$ & $3.8 \mathrm{~A}$ & $4 \mathrm{~A}$ & $2.3 \mathrm{~B}$ & $2 \mathrm{C}$ & $3 \mathrm{~A}$ & $4.7 \mathrm{~A}$ & $5 \mathrm{~A}$ & $5 \mathrm{~A}$ & $5 \mathrm{~A}$ \\
\hline 3 & $4.4 \mathrm{~A}$ & $4 \mathrm{~A}$ & $4.4 \mathrm{~A}$ & $4.8 \mathrm{~A}$ & $5 \mathrm{~A}$ & $4 \mathrm{~A}$ & $4 \mathrm{~A}$ & $5 \mathrm{~A}$ & $4.4 \mathrm{~A}$ & $4 \mathrm{AB}$ \\
\hline 4 & $4.8 \mathrm{~A}$ & $4 \mathrm{~A}$ & $3.5 \mathrm{~A}$ & $4.5 \mathrm{~A}$ & $4 \mathrm{~A}$ & $3 \mathrm{~A}$ & $3.5 \mathrm{~A}$ & $3.5 \mathrm{~B}$ & $4 \mathrm{~A}$ & $3.5 \mathrm{~B}$ \\
\hline 5 & $4.6 \mathrm{~A}$ & $3.8 \mathrm{~A}$ & $4.4 \mathrm{~A}$ & $3.6 \mathrm{~A}$ & 3.6AB & $4 \mathrm{~A}$ & $4.8 \mathrm{~A}$ & $4.8 \mathrm{~A}$ & $5 \mathrm{~A}$ & $5 \mathrm{~A}$ \\
\hline 6 & $4 \mathrm{~A}$ & $3.6 \mathrm{~A}$ & $4.2 \mathrm{~A}$ & $2.3 \mathrm{~B}$ & $2.4 \mathrm{BC}$ & $3.8 \mathrm{~A}$ & $4 \mathrm{~A}$ & $5 \mathrm{~A}$ & $5 \mathrm{~A}$ & 4.6AB \\
\hline
\end{tabular}

${ }^{a}$ Means with the same letter in a group of a column are not significantly different at $\alpha=0.05$ (ANOVA). 


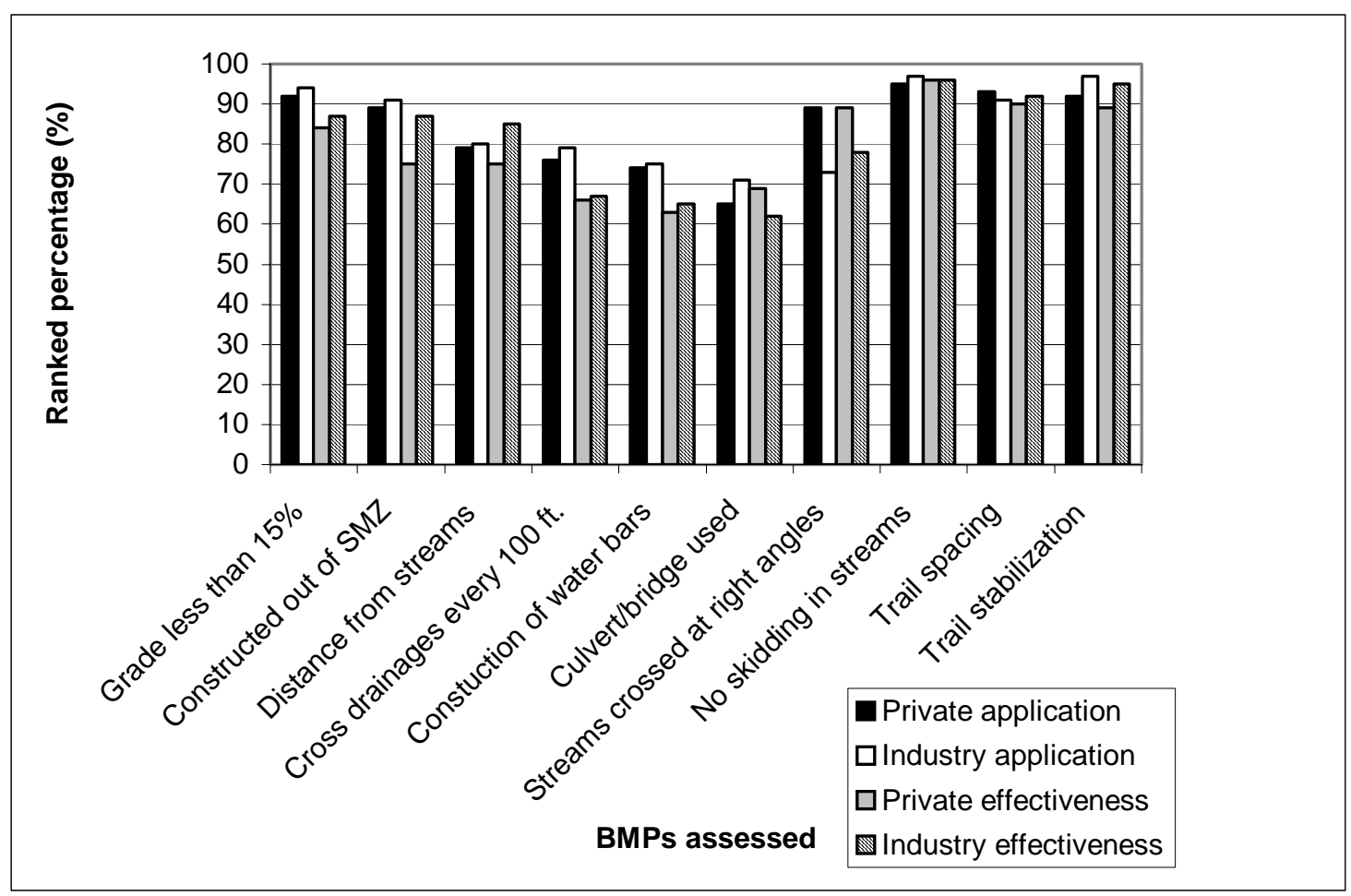

Figure 3.2. Skid trail application and effectiveness ranking percentage by ownership.

The application and effectiveness rankings for skid trails showed differences among ownership types. BMPs were applied more often on industry owned lands than on private lands (Figure 3.2). Similarly, the effectiveness of these BMPs also ranked higher on industry lands than on private lands.

\subsubsection{Landings}

The average application ranking for landings constructed outside of the SMZ was 2.5 (Table 3.25). Landings should be at least 25 feet away from ephemerals and 100 feet away from other streams. They should be placed on dry, firm sites. The skid trails coming into the landings should have water diversions installed to keep water from running down the trail and onto the 
landing. After the harvest is complete the landing should be seeded and mulched. The last BMP states that landings should be kept to a minimum size. The recommended size for a landing is a quarter of an acre depending on the terrain. Application levels of BMPs on the landings ranged from 2.4 to 2.9. The average effectiveness levels varied from 3.6 to 4.6 for all BMPs on the landings, which again indicated the average effectiveness of BMPs on the landings was from fair to good.

Table 3.25. Statistics of BMP application and effectiveness on landings.

\begin{tabular}{|c|c|c|c|c|c|c|c|c|c|}
\hline \multirow[b]{2}{*}{ BMP } & \multicolumn{5}{|c|}{ Application } & \multicolumn{4}{|c|}{ Effectiveness } \\
\hline & $\mathrm{N}$ & Mean & $\overline{\text { Std. De }}$ & Min & Max. & Mean & Std. Der & Min & Max \\
\hline Landing out of SMZ & 33 & 2.5 & 0.8 & 1 & 4 & 3.9 & 1.5 & 1 & 5 \\
\hline $\begin{array}{l}\text { Landing diverted from } \\
\text { water }\end{array}$ & 33 & 2.6 & 0.7 & 1 & 3 & 4.1 & 104 & 1 & 5 \\
\hline $\begin{array}{l}\text { Correct distance from } \\
\text { stream }\end{array}$ & 33 & 2.5 & 0.8 & 1 & 3 & 4 & 1.5 & 1 & 5 \\
\hline $\begin{array}{l}\text { Constructed on a } \\
\text { dry/firm site } \\
\text { Skid trails have water }\end{array}$ & 33 & 2.6 & 0.8 & 1 & 3 & 4 & 1.5 & 1 & 5 \\
\hline $\begin{array}{l}\text { Skid trails have water } \\
\text { diversion }\end{array}$ & 33 & 2.4 & 0.9 & 1 & 3 & 3.6 & 1.6 & 1 & 5 \\
\hline Landing seeded & 33 & 2.8 & 0.6 & 1 & 3 & 4.6 & 1.1 & 1 & 5 \\
\hline Landing mulched & 33 & 2.7 & 0.7 & 1 & 3 & 4.4 & 1.4 & 1 & 5 \\
\hline $\begin{array}{l}\text { Landing kept to } \\
\text { minimum size }\end{array}$ & 33 & 2.9 & 0.2 & 2 & 3 & 4.5 & 0.9 & 2 & 5 \\
\hline
\end{tabular}

Forester involvement did not significantly affect the BMP applications on landings (Table 3.26). Ranking on privately owned land for roads coming into the landing being diverted to prevent water from running onto the landing were lower than on industrial land (Table 3.26). This BMP had an application ranking of 2.2 on private lands compared to 3 on industrial owned land. There were no significant differences in all of the BMP applications on landings among harvest methods. 
Table 3.26. Means and significance levels of BMP application on landings. ${ }^{a}$

Landing Landing Correct Constructed Diversion Landing Landing Landing out of diverted distance on a for seeded mulched min. SMZ of water from streams dry/firm site skid trails size

\begin{tabular}{|c|c|c|c|c|c|c|c|c|}
\hline \multicolumn{9}{|c|}{ Forester Involvement } \\
\hline Yes & $2.7 \mathrm{~A}$ & $2.7 \mathrm{~A}$ & $2.5 \mathrm{~A}$ & $2.7 \mathrm{~A}$ & $2.5 \mathrm{~A}$ & $2.7 \mathrm{~A}$ & $2.7 \mathrm{~A}$ & $2.9 \mathrm{~A}$ \\
\hline No & $2.2 \mathrm{~A}$ & $2.4 \mathrm{~A}$ & $2.4 \mathrm{~A}$ & $2.5 \mathrm{~A}$ & $2.2 \mathrm{~A}$ & $2.9 \mathrm{~A}$ & $2.7 \mathrm{~A}$ & $3 \mathrm{~A}$ \\
\hline \multicolumn{9}{|c|}{ Ownership } \\
\hline Private & $2.4 \mathrm{~A}$ & $2.4 \mathrm{~A}$ & $2.5 \mathrm{~A}$ & $2.6 \mathrm{~A}$ & $2.2 \mathrm{~B}$ & $2.8 \mathrm{~A}$ & $2.8 \mathrm{~A}$ & $2.9 \mathrm{~A}$ \\
\hline Industrial & $2.8 \mathrm{~A}$ & $2.9 \mathrm{~A}$ & $2.5 \mathrm{~A}$ & $2.8 \mathrm{~A}$ & $3 \mathrm{~A}$ & $2.6 \mathrm{~A}$ & $2.6 \mathrm{~A}$ & $3 \mathrm{~A}$ \\
\hline \multicolumn{9}{|c|}{ Harvest Method } \\
\hline Clearcut & $2 \mathrm{~A}$ & $2.3 \mathrm{~A}$ & $2 \mathrm{~A}$ & $2.3 \mathrm{~A}$ & $2.3 \mathrm{~A}$ & $3 \mathrm{~A}$ & $3 \mathrm{~A}$ & $3 \mathrm{~A}$ \\
\hline Diameter & & & & & & & & \\
\hline Limit & $2.5 \mathrm{~A}$ & $2.7 \mathrm{~A}$ & $2.5 \mathrm{~A}$ & $2.7 \mathrm{~A}$ & $2.5 \mathrm{~A}$ & $2.7 \mathrm{~A}$ & $2.7 \mathrm{~A}$ & $2.9 \mathrm{~A}$ \\
\hline Selection & $2.6 \mathrm{~A}$ & $2.4 \mathrm{~A}$ & $2.6 \mathrm{~A}$ & $2.6 \mathrm{~A}$ & $2.3 \mathrm{~A}$ & $2.8 \mathrm{~A}$ & $2.7 \mathrm{~A}$ & $2.9 \mathrm{~A}$ \\
\hline \multicolumn{9}{|c|}{ Forest District } \\
\hline 1 & $2.6 \mathrm{~A}$ & $2.4 \mathrm{~A}$ & $2.6 \mathrm{~A}$ & $2.6 \mathrm{~A}$ & $2.1 \mathrm{~A}$ & $2.7 \mathrm{AB}$ & $2.7 \mathrm{~A}$ & $2.9 \mathrm{~A}$ \\
\hline 2 & $2.2 \mathrm{~A}$ & $2.3 \mathrm{~A}$ & $2.3 \mathrm{~A}$ & $2.3 \mathrm{~A}$ & $2.2 \mathrm{~A}$ & $3 \mathrm{~A}$ & $2.7 \mathrm{~A}$ & $3 \mathrm{~A}$ \\
\hline 3 & $3 \mathrm{~A}$ & $2.8 \mathrm{~A}$ & $2.6 \mathrm{~A}$ & $3 \mathrm{~A}$ & $3 \mathrm{~A}$ & $2.4 \mathrm{AB}$ & $2.4 \mathrm{~A}$ & $3 \mathrm{~A}$ \\
\hline 4 & $3 \mathrm{~A}$ & $3 \mathrm{~A}$ & $3 \mathrm{~A}$ & $3 \mathrm{~A}$ & $3 \mathrm{~A}$ & 2B & $2 \mathrm{~A}$ & $2.5 \mathrm{~B}$ \\
\hline 5 & $3 \mathrm{~A}$ & $3 \mathrm{~A}$ & $2.8 \mathrm{~A}$ & $3 \mathrm{~A}$ & $2.8 \mathrm{~A}$ & $3 \mathrm{~A}$ & $3 \mathrm{~A}$ & $3 \mathrm{~A}$ \\
\hline 6 & $1.9 \mathrm{~A}$ & $2.3 \mathrm{~A}$ & $2.1 \mathrm{~A}$ & $2.3 \mathrm{~A}$ & $2 \mathrm{~A}$ & $3 \mathrm{~A}$ & $3 \mathrm{~A}$ & $3 \mathrm{~A}$ \\
\hline
\end{tabular}

Forester involvement significantly affected the effectiveness levels of landing size ( $\mathrm{F}=6.95$; $\mathrm{df}=1,32 ; \mathrm{P}=0.0148$ ). Without forester involvement the effectiveness ranking was 4.9 , and 4.2 with forester involvement (Table 3.27). The effectiveness of roads that were diverted into the landing was significantly lower on privately owned lands than industrial owned lands $(\mathrm{F}=5.64 ; \mathrm{df}=1,32$; $\mathrm{P}=0.0304$ ). Diameter limit cut sites had a significantly higher effectiveness ranking of 4.4 for landings that were constructed on dry/firm sites compared to the other two harvest methods 
( $\mathrm{F}=4.09 ; \mathrm{df}=2,32 ; \mathrm{P}=0.0368)$. Districts two and five had significantly higher rankings for landings being kept to a minimum size with an effectiveness ranking of 5 , which was significantly different from the other districts $(\mathrm{F}=2.88 ; \mathrm{df}=5,32 ; \mathrm{P}=0.0484)$. Significant differences were found among the interactions of forester and districts, and between owner and harvest method for this BMP.

Table 3.27. Means and significance levels of BMP effectiveness on landings. ${ }^{\mathrm{a}}$

\begin{tabular}{|c|c|c|c|c|c|c|c|c|}
\hline & $\begin{array}{c}\text { Landing } \\
\text { out of } \\
\text { SMZ }\end{array}$ & $\begin{array}{l}\text { Landing } \\
\text { diverted } \\
\text { of water }\end{array}$ & $\begin{array}{c}\text { Correct } \\
\text { distance } \\
\text { from streams }\end{array}$ & $\begin{array}{c}\text { Constructed } \\
\text { on a } \\
\text { dry/firm site } \\
\end{array}$ & $\begin{array}{c}\text { Diversion } \\
\text { for } \\
\text { skid trails } \\
\end{array}$ & $\begin{array}{c}\text { Landing } \\
\text { seeded }\end{array}$ & $\begin{array}{l}\text { Landing } \\
\text { mulched }\end{array}$ & $\begin{array}{c}\text { Landing } \\
\text { min. } \\
\text { size }\end{array}$ \\
\hline \multicolumn{9}{|c|}{ Forester Involvement } \\
\hline Yes & $4.1 \mathrm{~A}$ & $4.4 \mathrm{~A}$ & $4.2 \mathrm{~A}$ & $4.2 \mathrm{~A}$ & $3.8 \mathrm{~A}$ & $4.5 \mathrm{~A}$ & $4.4 \mathrm{~A}$ & $4.2 \mathrm{~B}$ \\
\hline No & $3.6 \mathrm{~A}$ & $3.6 \mathrm{~A}$ & $3.8 \mathrm{~A}$ & $3.9 \mathrm{~A}$ & $3.3 \mathrm{~A}$ & $4.6 \mathrm{~A}$ & $4.4 \mathrm{~A}$ & $4.9 \mathrm{~A}$ \\
\hline \multicolumn{9}{|c|}{ Ownership } \\
\hline Private & $3.9 \mathrm{~A}$ & $3.9 \mathrm{~A}$ & $4 \mathrm{~A}$ & $4 \mathrm{~A}$ & $3.3 \mathrm{~B}$ & $4.7 \mathrm{~A}$ & $4.4 \mathrm{~A}$ & $4.6 \mathrm{~A}$ \\
\hline Industrial & $3.9 \mathrm{~A}$ & $4.6 \mathrm{~A}$ & $4 \mathrm{~A}$ & $4 \mathrm{~A}$ & 4.6A & $4.3 \mathrm{~A}$ & $4.3 \mathrm{~A}$ & $4.4 \mathrm{~A}$ \\
\hline \multicolumn{9}{|c|}{ Harvest Method } \\
\hline $\begin{array}{l}\text { Clearcut } \\
\text { Diameter }\end{array}$ & $2.7 \mathrm{~A}$ & $3 \mathrm{~A}$ & $2.7 \mathrm{~A}$ & $2.7 \mathrm{~B}$ & $3.3 \mathrm{~A}$ & $5 \mathrm{~A}$ & $5 \mathrm{~A}$ & $4 \mathrm{~A}$ \\
\hline Limit & $4.1 \mathrm{~A}$ & $4.4 \mathrm{~A}$ & $4.1 \mathrm{~A}$ & $4.4 \mathrm{~A}$ & $3.9 \mathrm{~A}$ & $4.5 \mathrm{~A}$ & $4.4 \mathrm{~A}$ & $4.6 \mathrm{~A}$ \\
\hline Selection & $3.9 \mathrm{~A}$ & $3.9 \mathrm{~A}$ & $4.1 \mathrm{~A}$ & $4 \mathrm{AB}$ & $3.4 \mathrm{~A}$ & $4.6 \mathrm{~A}$ & $4.3 \mathrm{~A}$ & $4.6 \mathrm{~A}$ \\
\hline \multicolumn{9}{|c|}{ Forest District } \\
\hline 1 & $4.1 \mathrm{~A}$ & $4 \mathrm{~A}$ & $4.3 \mathrm{~A}$ & $4.1 \mathrm{~A}$ & $3.6 \mathrm{~A}$ & $4.3 \mathrm{~A}$ & $4.3 \mathrm{~A}$ & $4.6 \mathrm{AB}$ \\
\hline 2 & $3.3 \mathrm{~A}$ & $3.5 \mathrm{~A}$ & $3.7 \mathrm{~A}$ & $3.7 \mathrm{~A}$ & $3.2 \mathrm{~A}$ & $5 \mathrm{~A}$ & $4.3 \mathrm{~A}$ & $5 \mathrm{~A}$ \\
\hline 3 & $4.4 \mathrm{~A}$ & $4.4 \mathrm{~A}$ & $4.2 \mathrm{~A}$ & $4.2 \mathrm{~A}$ & $4 \mathrm{~A}$ & $3.8 \mathrm{~A}$ & $3.8 \mathrm{~A}$ & $3.8 \mathrm{~B}$ \\
\hline 4 & $5 \mathrm{~A}$ & $5 \mathrm{~A}$ & $5 \mathrm{~A}$ & $5 \mathrm{~A}$ & $5 \mathrm{~A}$ & $4 \mathrm{~A}$ & $3 \mathrm{~A}$ & $3.5 \mathrm{~B}$ \\
\hline 5 & $4.8 \mathrm{~A}$ & $5 \mathrm{~A}$ & $4.8 \mathrm{~A}$ & $5 \mathrm{~A}$ & $4.6 \mathrm{~A}$ & $5 \mathrm{~A}$ & $5 \mathrm{~A}$ & $5 \mathrm{~A}$ \\
\hline 6 & $2.9 \mathrm{~A}$ & $3.5 \mathrm{~A}$ & $3.1 \mathrm{~A}$ & $3.3 \mathrm{~A}$ & $2.8 \mathrm{~A}$ & $4.9 \mathrm{~A}$ & $4.9 \mathrm{~A}$ & $4.5 \mathrm{AB}$ \\
\hline
\end{tabular}




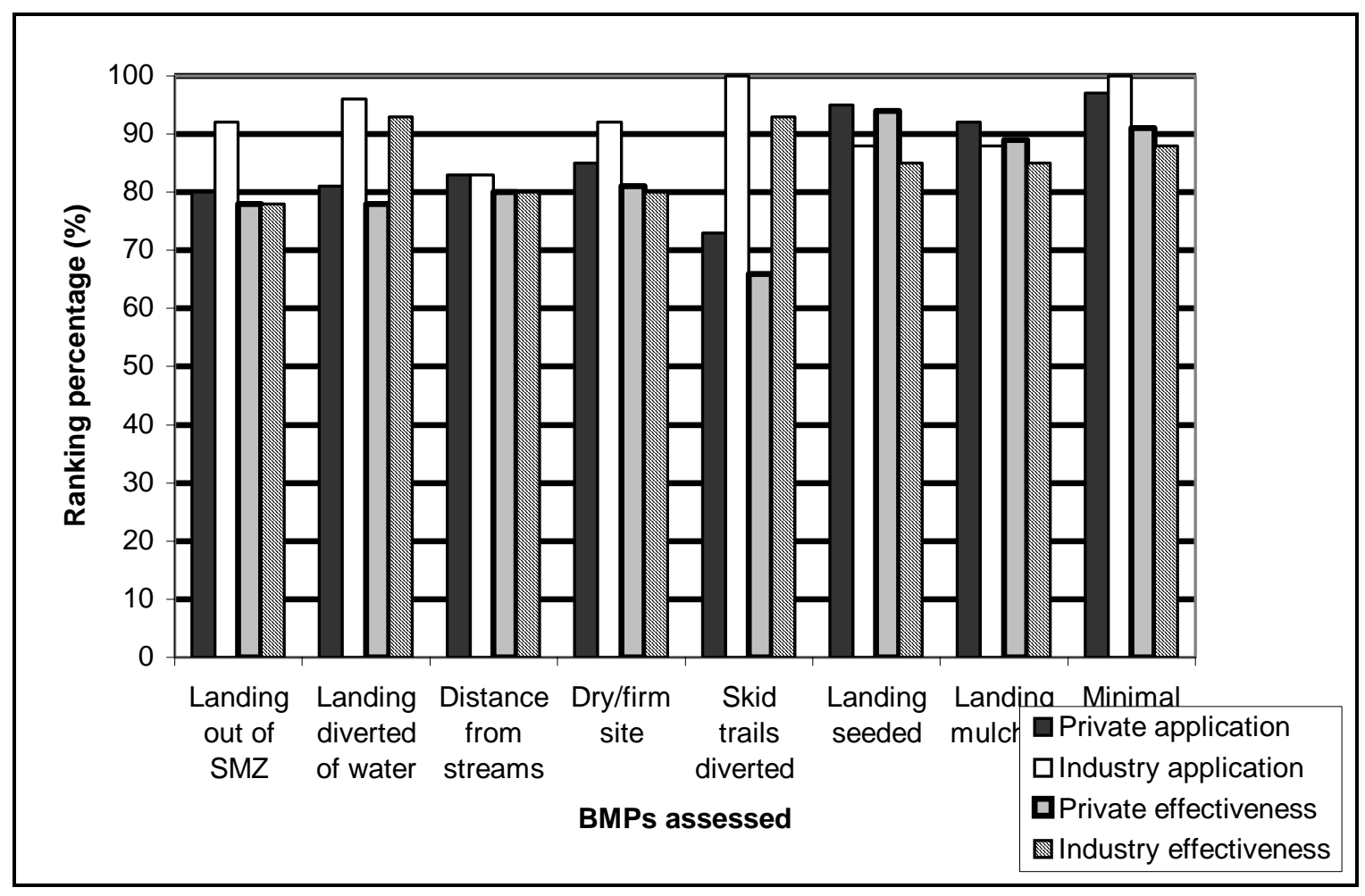

Figure 3.3. BMP application and effectiveness ranking percentage on landings by ownership.

The BMPs assessed on landings showed more variation than on haul roads and skid trails. The application of BMPs ranked lower on private land, except for landings that were seeded and mulched (Figure 3.3). The effectiveness ranking for all the BMPs were consistently less on private lands than they were on industry lands.

\subsubsection{SMZs}

SMZs are sensitive areas that usually require a lot of attention during operations. It is difficult to reclaim these sites back to the levels before harvest. Perennial and intermittent streams require a 100 foot buffer, while ephemeral streams only require a 25 foot buffer.

Whether or not there were equipment operations in the SMZ is permissible, but should be kept to a minimum. The landing should always be constructed outside of the SMZ. The application 
ranking of the landings being constructed outside of the SMZ was 2.4, which means the BMP was applied, but not as often as it should have been (Table 3.28). The SMZ should be smooth and not contain any ruts, and also needs to be seeded and mulched. When SMZs must be entered for a harvest it is recommended that they have minimum cut and fill slopes. This will limit the amount of disturbance to the area, and keep it as natural as possible. The application of BMPs in the SMZs ranged from 2.4 to 3 while the effectiveness levels were between 3.8 and 4.7 ranking from fair to good effectiveness.

Table 3.28. Statistics of BMP application and effectiveness in SMZs.

\begin{tabular}{|c|c|c|c|c|c|c|c|c|c|}
\hline & & \multicolumn{4}{|c|}{ Application } & \multicolumn{4}{|c|}{ Effectiveness } \\
\hline BMP & $\mathrm{N}$ & Mean & Std. Dev. & Min. & $\operatorname{Max}$ & Mean & Std. Dev. & Min & Max. \\
\hline 100ft. Buffer & 33 & 2.7 & 0.5 & 1 & 3 & 3.9 & 1.1 & 1 & 5 \\
\hline 25ft. Buffer & 21 & 2.9 & 0.2 & 2 & 3 & 4.7 & 0.7 & 2 & 5 \\
\hline Minimum equipment use & 33 & 2.7 & 0.5 & 2 & 3 & 3.9 & 1.1 & 2 & 5 \\
\hline Landing out of SMZ & 33 & 2.4 & 0.8 & 1 & 3 & 3.8 & 1.6 & 1 & 5 \\
\hline SMZ smooth & 33 & 2.9 & 0.2 & 2 & 3 & 4.7 & 0.8 & 2 & 5 \\
\hline SMZ seeded & 33 & 2.8 & 0.6 & 1 & 3 & 4.5 & 1.2 & 1 & 5 \\
\hline SMZ mulched & 33 & 2.8 & 0.7 & 1 & 3 & 4.4 & 1.3 & 1 & 5 \\
\hline $\begin{array}{l}\text { Haul road reclaimed if } \\
\text { needed }\end{array}$ & 13 & 2.5 & 0.9 & 1 & 3 & 4 & 1.6 & 1 & 5 \\
\hline in SMZ & 32 & 3 & 0 & 3 & 3 & 4.8 & 0.6 & 3 & 5 \\
\hline
\end{tabular}

There were no significant differences for the BMPs assessed on SMZs between forester involvement, among ownership, and among districts (Table 3.29). Clearcut sites had a significantly lower application ranking than the other two methods with a ranking of 2.7 for the $\mathrm{BMP}$ of reclaiming the $\mathrm{SMZ}$ for proper drainage and no rutting $(\mathrm{F}=1.28 ; \mathrm{df}=2 ; \mathrm{p}=0.0235)$. 
Table 3.29. Means and significance levels of BMP applications in SMZs. ${ }^{a}$ $100 \mathrm{ft} .25 \mathrm{ft}$. Minimum Landing SMZ SMZ SMZ Haul Road Minimum width width equipment use outside SMZ smooth seeded mulched reclaimed cut/fill slopes

\begin{tabular}{|c|c|c|c|c|c|c|c|c|c|}
\hline \multicolumn{10}{|c|}{ Forester Involvement } \\
\hline Yes & $2.8 \mathrm{~A}$ & $2.9 \mathrm{~A}$ & $2.7 \mathrm{~A}$ & $2.6 \mathrm{~A}$ & $2.9 \mathrm{~A}$ & $2.9 \mathrm{~A}$ & $2.9 \mathrm{~A}$ & $2.4 \mathrm{~A}$ & $2.9 \mathrm{~A}$ \\
\hline No & $2.6 \mathrm{~A}$ & $3 \mathrm{~A}$ & $2.7 \mathrm{~A}$ & $2.2 \mathrm{~A}$ & $3 \mathrm{~A}$ & $2.7 \mathrm{~A}$ & $2.6 \mathrm{~A}$ & $2.4 \mathrm{~A}$ & $3 \mathrm{~A}$ \\
\hline \multicolumn{10}{|c|}{ Ownership } \\
\hline Private & $2.6 \mathrm{~A}$ & $2.9 \mathrm{~A}$ & $2.7 \mathrm{~A}$ & $2.4 \mathrm{~A}$ & $3 \mathrm{~A}$ & $2.8 \mathrm{~A}$ & $2.7 \mathrm{~A}$ & $2.5 \mathrm{~A}$ & $2.9 \mathrm{~A}$ \\
\hline Industrial & $2.9 \mathrm{~A}$ & $3 \mathrm{~A}$ & $2.8 \mathrm{~A}$ & $2.4 \mathrm{~A}$ & $2.9 \mathrm{~A}$ & $3 \mathrm{~A}$ & $3 \mathrm{~A}$ & $2.3 \mathrm{~A}$ & $3 \mathrm{~A}$ \\
\hline \multicolumn{10}{|c|}{ Harvest Method } \\
\hline Clearcut & $2.7 \mathrm{~A}$ & $3 \mathrm{~A}$ & $2.3 \mathrm{~A}$ & $1.7 \mathrm{~A}$ & $2.7 \mathrm{~B}$ & $2.3 \mathrm{~A}$ & $2.3 \mathrm{~A}$ & $3 \mathrm{~A}$ & $3 \mathrm{~A}$ \\
\hline Diameter & & & & & & & & & \\
\hline Limit & $2.7 \mathrm{~A}$ & $2.9 \mathrm{~A}$ & $2.7 \mathrm{~A}$ & $2.5 \mathrm{~A}$ & $3 \mathrm{~A}$ & $3 \mathrm{~A}$ & $3 \mathrm{~A}$ & $2.2 \mathrm{~A}$ & $3 \mathrm{~A}$ \\
\hline Selection & $2.7 \mathrm{~A}$ & $3 \mathrm{~A}$ & $2.8 \mathrm{~A}$ & $2.5 \mathrm{~A}$ & $3 \mathrm{~A}$ & $2.7 \mathrm{~A}$ & $2.6 \mathrm{~A}$ & $2.5 \mathrm{~A}$ & $2.9 \mathrm{~A}$ \\
\hline \multicolumn{10}{|c|}{ Forest District } \\
\hline 1 & $2.8 \mathrm{~A}$ & $3 \mathrm{~A}$ & $2.8 \mathrm{~A}$ & $2.5 \mathrm{~A}$ & $3 \mathrm{~A}$ & $2.7 \mathrm{~A}$ & $2.7 \mathrm{~A}$ & $3 \mathrm{~A}$ & $2.7 \mathrm{~A}$ \\
\hline 2 & $2.5 \mathrm{~A}$ & $3 \mathrm{~A}$ & $2.8 \mathrm{~A}$ & $2.3 \mathrm{~A}$ & $3 \mathrm{~A}$ & $2.7 \mathrm{~A}$ & $2.3 \mathrm{~A}$ & $2.5 \mathrm{~A}$ & $3 \mathrm{~A}$ \\
\hline 3 & $3 \mathrm{~A}$ & $3 \mathrm{~A}$ & $2.8 \mathrm{~A}$ & $2.4 \mathrm{~A}$ & $2.8 \mathrm{~A}$ & $2.6 \mathrm{~A}$ & $2.6 \mathrm{~A}$ & $2 \mathrm{~A}$ & $3 \mathrm{~A}$ \\
\hline 4 & $2.5 \mathrm{~A}$ & $3 \mathrm{~A}$ & $2.5 \mathrm{~A}$ & $3 \mathrm{~A}$ & $3 \mathrm{~A}$ & $3 \mathrm{~A}$ & $3 \mathrm{~A}$ & $2 \mathrm{~A}$ & $3 \mathrm{~A}$ \\
\hline 5 & $3 \mathrm{~A}$ & $2.8 \mathrm{~A}$ & $3 \mathrm{~A}$ & $3 \mathrm{~A}$ & $3 \mathrm{~A}$ & $3 \mathrm{~A}$ & $3 \mathrm{~A}$ & $2 \mathrm{~A}$ & $3 \mathrm{~A}$ \\
\hline 6 & $2.4 \mathrm{~A}$ & $3 \mathrm{~A}$ & $2.4 \mathrm{~A}$ & $1.9 \mathrm{~A}$ & $3 \mathrm{~A}$ & $3 \mathrm{~A}$ & $3 \mathrm{~A}$ & $3 \mathrm{~A}$ & $3 \mathrm{~A}$ \\
\hline
\end{tabular}

${ }^{\mathrm{a}}$ Means with the same letter in a group of a column are not significantly different at $\alpha=0.05$ (ANOVA).

The clearcut site also had a significantly lower effectiveness ranking for minimum of cut/fill slopes with a ranking of $3.5(\mathrm{~F}=3.52 ; \mathrm{df}=2,32 ; \mathrm{P}=0.042)$ (Table 3.30). Districts three and four had significantly lower effectiveness rankings for limited equipment operations inside a SMZ with a ranking of 3 , which differed significantly from the other districts $(\mathrm{F}=5.22 ; \mathrm{df}=5,32$; $\mathrm{P}=0.0026)$. 
Table 3.30. Means and significance levels of BMP effectiveness in SMZs. ${ }^{a}$ $100 \mathrm{ft} .25 \mathrm{ft}$. Minimum Landing SMZ SMZ SMZ Haul Road Minimum width width equipment use outside SMZ smooth seeded mulched reclaimed cut/fill slopes

\begin{tabular}{|c|c|c|c|c|c|c|c|c|c|}
\hline \multicolumn{10}{|c|}{ Forester Involvement } \\
\hline Yes & $4.1 \mathrm{~A}$ & $4.6 \mathrm{~A}$ & $3.7 \mathrm{~A}$ & $4.2 \mathrm{~A}$ & $4.6 \mathrm{~A}$ & $4.5 \mathrm{~A}$ & $4.7 \mathrm{~A}$ & $4 \mathrm{~A}$ & $4.6 \mathrm{~A}$ \\
\hline No & $3.6 \mathrm{~A}$ & $4.8 \mathrm{~A}$ & $4.1 \mathrm{~A}$ & $3.2 \mathrm{~A}$ & $4.9 \mathrm{~A}$ & $4.4 \mathrm{~A}$ & $4 \mathrm{~A}$ & $3.7 \mathrm{~A}$ & $4.7 \mathrm{~A}$ \\
\hline \multicolumn{10}{|c|}{ Ownership } \\
\hline Private & $3.8 \mathrm{~A}$ & $4.5 \mathrm{~A}$ & $4 \mathrm{~A}$ & $3.8 \mathrm{~A}$ & $4.8 \mathrm{~A}$ & $4.3 \mathrm{~A}$ & $4.3 \mathrm{~A}$ & $3.9 \mathrm{~A}$ & $4.7 \mathrm{~A}$ \\
\hline Industrial & $4 \mathrm{~A}$ & $4.9 \mathrm{~A}$ & $3.5 \mathrm{~A}$ & $3.6 \mathrm{~A}$ & $4.5 \mathrm{~A}$ & $4.9 \mathrm{~A}$ & $4.6 \mathrm{~A}$ & $3.7 \mathrm{~A}$ & 4.6 \\
\hline \multicolumn{10}{|c|}{ Harvest Method } \\
\hline Clearcut & $4 \mathrm{~A}$ & $5 \mathrm{~A}$ & $3.3 \mathrm{~A}$ & $2.3 \mathrm{~A}$ & $4 \mathrm{~A}$ & $4 \mathrm{~A}$ & $4 \mathrm{~A}$ & $5 \mathrm{~A}$ & $3.5 \mathrm{~B}$ \\
\hline Diameter & & & & & & & & & \\
\hline Limit & $3.9 \mathrm{~A}$ & $4.8 \mathrm{~A}$ & $3.8 \mathrm{~A}$ & $3.9 \mathrm{~A}$ & $4.8 \mathrm{~A}$ & $4.8 \mathrm{~A}$ & $4.6 \mathrm{~A}$ & $3.2 \mathrm{~A}$ & $4.9 \mathrm{~A}$ \\
\hline Selection & $3.9 \mathrm{~A}$ & $4.4 \mathrm{~A}$ & $4.1 \mathrm{~A}$ & $3.9 \mathrm{~A}$ & $4.7 \mathrm{~A}$ & $4.3 \mathrm{~A}$ & $4.2 \mathrm{~A}$ & $4.1 \mathrm{~A}$ & $4.6 \mathrm{~A}$ \\
\hline \multicolumn{10}{|c|}{ Forest District } \\
\hline 1 & $4.7 \mathrm{~A}$ & $4.8 \mathrm{~A}$ & $4.3 \mathrm{AB}$ & $4.2 \mathrm{~A}$ & $4.8 \mathrm{~A}$ & $4.3 \mathrm{~A}$ & $4.3 \mathrm{~A}$ & $5 \mathrm{~A}$ & $4.3 \mathrm{~A}$ \\
\hline 2 & $4 \mathrm{AB}$ & $4.7 \mathrm{~A}$ & $4.5 \mathrm{AB}$ & $3.5 \mathrm{~A}$ & $5 \mathrm{~A}$ & $4.3 \mathrm{~A}$ & $3.7 \mathrm{~A}$ & $4.3 \mathrm{~A}$ & $4.7 \mathrm{~A}$ \\
\hline 3 & $3.4 \mathrm{~B}$ & $4.3 \mathrm{~A}$ & $3 \mathrm{C}$ & $3.6 \mathrm{~A}$ & $3.6 \mathrm{~B}$ & $3.6 \mathrm{~A}$ & $3.8 \mathrm{~A}$ & $3 \mathrm{~A}$ & $4.3 \mathrm{~A}$ \\
\hline 4 & 3B & $4.5 \mathrm{~A}$ & $3 \mathrm{C}$ & $5 \mathrm{~A}$ & $4.5 \mathrm{AB}$ & $4 \mathrm{~A}$ & $4 \mathrm{~A}$ & $3 \mathrm{~A}$ & $4.5 \mathrm{~A}$ \\
\hline 5 & $4.8 \mathrm{~A}$ & $4.8 \mathrm{~A}$ & $4.6 \mathrm{~A}$ & $5 \mathrm{~A}$ & $5 \mathrm{~A}$ & $5 \mathrm{~A}$ & $5 \mathrm{~A}$ & $2 \mathrm{~A}$ & $5 \mathrm{~A}$ \\
\hline 6 & $3.1 \mathrm{~B}$ & $5 \mathrm{~A}$ & $3.4 \mathrm{BC}$ & $2.6 \mathrm{~A}$ & 4.9A & $5 \mathrm{~A}$ & $5 \mathrm{~A}$ & $5 \mathrm{~A}$ & $4.9 \mathrm{~A}$ \\
\hline
\end{tabular}




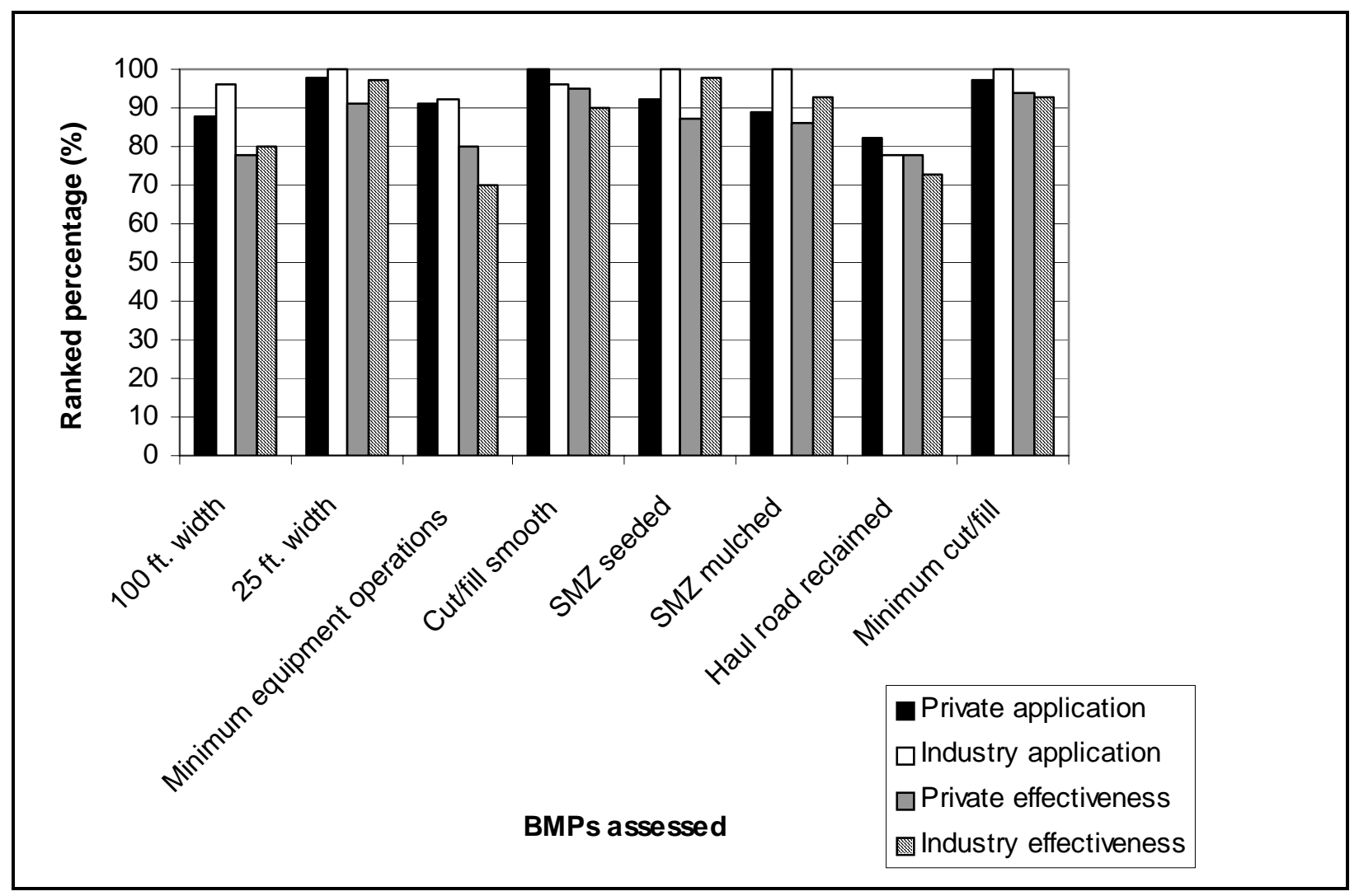

Figure 3.4. BMP application and effectiveness ranking percentage in SMZs by ownership.

For the BMPs assessed in SMZs the BMPs on industry lands presented higher application rates. However, the effectiveness levels are lower on industry lands for some of the BMPs (Figure 3.4). The SMZs were seeded and mulched with greater application and effectiveness on industry lands.

The application and effectiveness ranking of each BMP was converted into a percentage by adding the total rankings for each BMP and dividing them by the total possible rankings for that BMP (Figure 3.5). This process allowed for each BMP to be viewed as a percentage. The BMPs with the lowest rankings apply to construction and placement of cross drainages. These were the only BMPs that were at, or below 70\%. The majority of the BMPs received very high rankings of both application and effectiveness. 


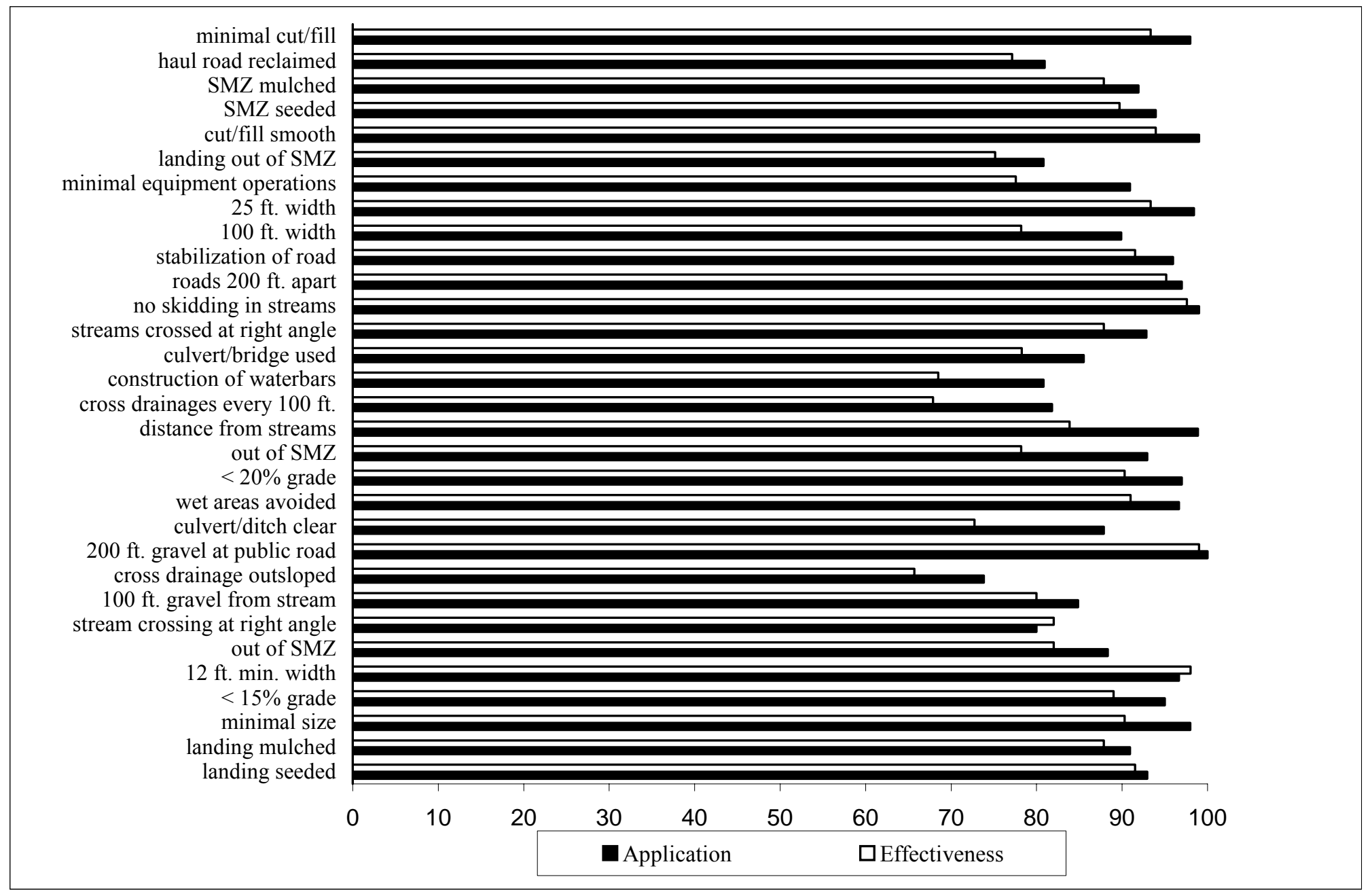

Figure 3.5. Application and Effectiveness rankings shown as percentages. 


\subsection{Responses of Landowners to BMPs and Harvests}

Each landowner was asked a series of questions to determine their BMP knowledge, participation level, and responses to operations during the harvest. One of the questions involved the landowners' knowledge of any BMP violations that may have occurred during the harvest. Only six landowners reported some knowledge about BMP violation. The violations included lack of waterbars, no reclamation, steep grades, and one instance of no gravel applied to the haul road.

Landowners were also asked to report any problems they may have had during the harvest. Only nine landowners reported having had a problem. The problems that occurred were specific to each landowner. One landowner reported that his septic tank had been cracked due to the harvest. He had told the logger where it was, but then noticed that the logger had used this area for the landing. Another landowner said that his fields had been torn up, and were never reclaimed by the logger. One landowner had roads built through his yard that were never reclaimed. Another site had a mudslide at the driveway just after the harvest. The landowner believed the cause to be a road that had been built, which undercut the hillside.

The questionnaire asked if the loggers had followed the specifications set by the landowners. Only $8 \%$ of the landowners answered no to this question, and $3 \%$ said they had not yet seen the harvest.

Landowners were also asked how they got in contact with the logger for the first time. Six percent of the landowners said they contacted the logger. Another $10 \%$ of the landowners were approached by the logger. Only $8 \%$ of the landowners used a forester or consultant. Two percent of the landowners knew the loggers previously. Four percent of the tracts were owned and 
harvested by the same person. Contract loggers were used on $26 \%$ of the tracts. Forty three percent of the tracts were sold by a bid sale.

The statistics from the landowner questionnaire were summarized in Table 3.31. Districts two and five had the lowest satisfaction levels with the harvest and BMPs. Districts three and six had the most problems occur during harvests with $17 \%$ of the landowners citing problems with the harvest. The higher percentage of BMP violations were also noticed by the landowners in these two districts. In district two, only $82 \%$ of the loggers followed the specifications set by landowners. The next highest percentage for loggers following specifications was ninety percent. However, in district two, none of the landowners reported noticing any erosion after the harvest. District one had the least amount of landowners who performed maintenance on the road postharvest. Each of the other five districts showed at least $11 \%$ of the landowners performing maintenance to their roads once the harvest is complete. District one also had the highest percentage of positive recommendations for the logger by the landowner with $96 \%$, while the lowest recommendation percentage was noted in district six with $89 \%$.

Table 3.31. A summary of the questions to Landowners in percentage.

\begin{tabular}{lccccccc} 
& \multicolumn{6}{c}{ District } \\
\cline { 2 - 7 } Questions & 1 & 2 & 3 & 4 & 5 & 6 \\
\hline Landowner Satisfied & 96 & 82 & 90 & 90 & 77 & 89 \\
Had Problems & 8 & 0 & 17 & 10 & 5 & 17 \\
Noticed Violations & 4 & 0 & 10 & 0 & 0 & 11 \\
Logger Followed Specifications & 96 & 82 & 90 & 90 & 94 & 94 \\
Noticed Erosion & 4 & 0 & 13 & 10 & 12 & 11 \\
Performed Maintenance & 2 & 24 & 20 & 20 & 18 & 11 \\
Landowner Recommendation & 96 & 94 & 90 & 90 & 94 & 89 \\
\hline
\end{tabular}

The answers to the landowner questions were also summarized by ownership (Table 3.32). Private landowners had a satisfaction level of $90 \%$, while industrial landowners only had $85 \%$ satisfaction. Nine percent of private landowners responded that they had problems with the harvest 
operation. Industrial landowners reported problems on $13 \%$ of the sites. Only $3 \%$ of the private landowners noticed any BMP violations, and 10\% of industrial landowners noticed BMP violations. Each landowner type felt that the logger followed specifications $90 \%$ of the time. Erosion was noticed on both private and industrial lands on $9 \%$ and $8 \%$ of the sites, respectively. Maintenance was performed on $18 \%$ of the private lands, which is $5 \%$ more than the industrial lands with $8 \%$. Of the 116 landowners only $11 \%$ of them would not recommend the logger to someone else. Four of the landowners, who did not respond to this question, performed the harvest themselves.

Table 3.32. Landowner statistics by ownership in percentage.

\begin{tabular}{lcc}
\hline Questions & Private Landowner & Industrial Landowner \\
\hline Landowner Satisfied & 90 & 85 \\
Had Problems & 9 & 13 \\
Noticed Violations & 3 & 10 \\
Logger Followed Specifications & 90 & 90 \\
Noticed Erosion & 9 & 8 \\
Performed Maintenance & 18 & 13 \\
Landowner Recommendation & 87 & 92 \\
\hline
\end{tabular}

\subsection{Spatial Analysis of BMPs in SMZs}

Spatial analysis of BMPs was conducted for each site with SMZs. Landing size was determined for each site, as well as soil type and characteristics. Using spatial analysis, relationships among compliance, application, and effectiveness to spatial data collected from the field were examined. Sample figures of the data used in ArcMap were placed in this section. Results from these sample sites, as well as results by stream and soil type, and SMZ width for the combined sites were also used. The use of specific sites and their results related to the sample figures enabled a visual aid for the data used. 
Flow accumulation rasters, which were created from an elevation grid were used to determine stream crossings compared to levels of flow. The raindrop tool in ArcMap was used to determine overland flow during precipitation events. The use of this tool allowed analysis of areas on the harvest that may have required more reclamation or better planning. Landing and road location were specifically analyzed to see if better placement would have decreased the risk of erosion.

Results showed that well placed landings and roads received higher compliance levels. When stream crossings were reclaimed and constructed at low flow accumulation points fewer problems were found. This indicates that pre-harvest planning can improve the compliance level of a site.

\subsubsection{Stream Type}

Of the 33 sites $43 \%$ contained intermittent streams, $34 \%$ were ephemeral streams, and $17 \%$ were perennial streams. Perennial and intermittent streams require a $100 \mathrm{ft}$. buffer for the SMZ (WVDOF 2002).

A poor example of SMZ buffer application is illustrated in Figure 3.6. The flow accumulation raster shows that the greatest amount of water is passing directly by or over the landing. Two of the skid trails cross the stream at high accumulation points. Due to the landing elevation and placement, the skid trails run downward onto the landing. This site in particular did not have the required number of water bars, and the ones that were in place received low effectiveness rankings. The grade of the skid trails exceeded $15 \%$ on numerous sections. Using this information and the soil characteristic of "slight" for both erosion and equipment limitation we can see where the greatest runoff may occur. The raindrop tool shows how overland flow will 
drain. Without the proper water diversion, water would flow directly down the skid trail and into the stream. Sediment was noticed on this site, but there was sufficient seeding and mulching on the skid trails and landing to reduce most of the runoff. The compliance for this site was $78 \%$. This was due to the proper reclamation of the steep skid trails, and a great amount of detail to the seeding and mulching of disturbed areas. Even with the steep grades and lack of water bars this site had high application and effectiveness levels for the other BMPs assessed.

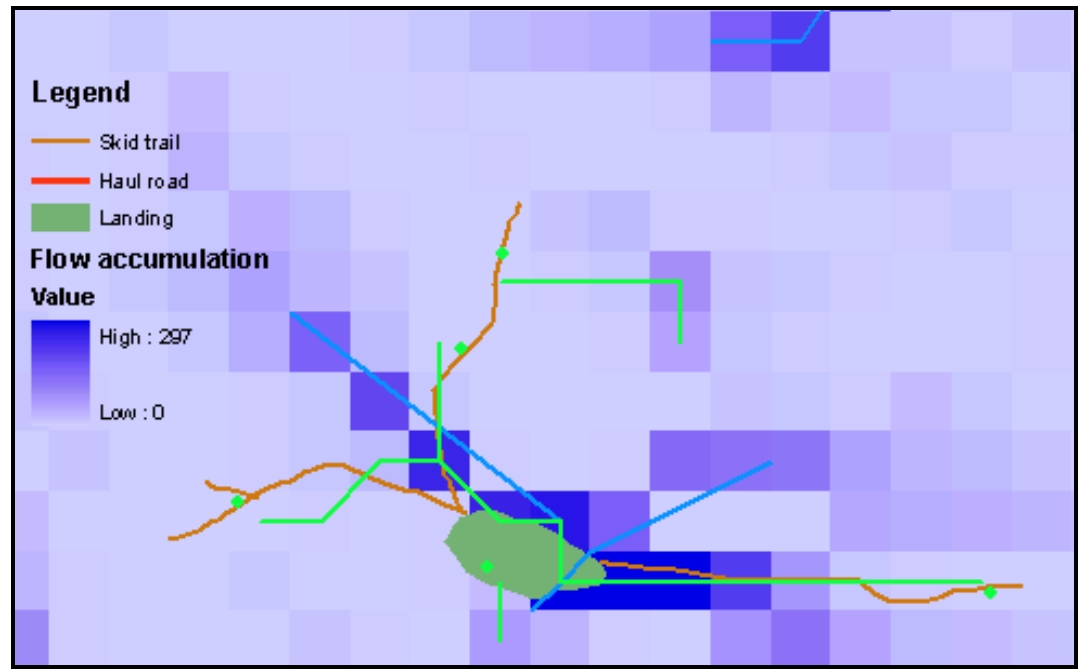

Figure 3.6. Poor application on perennial stream.

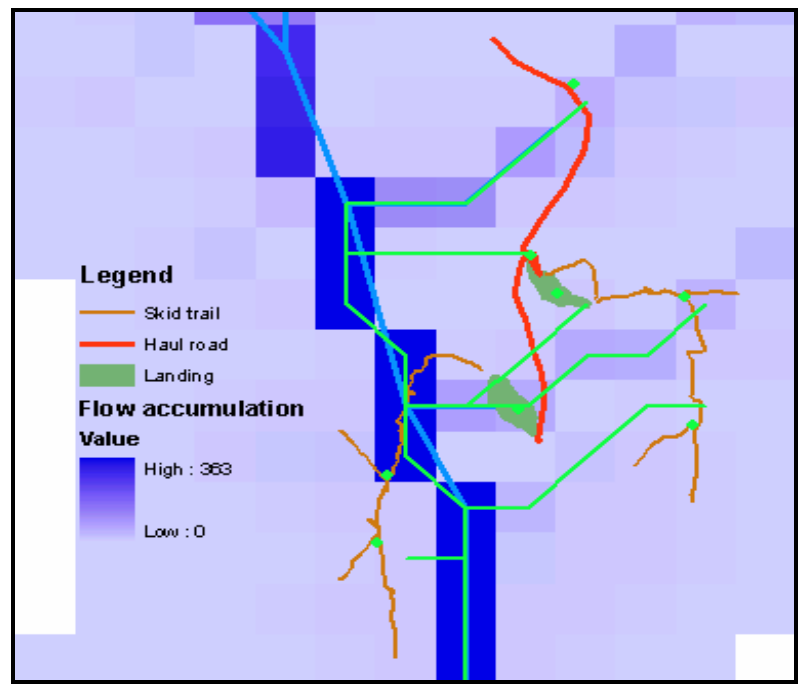

Figure 3.7. Good application of perennial stream. 
Another site with a perennial stream, in which BMPs were applied with good effectiveness in the SMZ is shown in Figure 3.7. A major stream runs around the landing site, and along the skid trail. Soils on this site have "slight" erosion hazards and equipment limitations. The landing had no water diversion, and was not located on a dry site. It was seeded and mulched, but was located directly beside a stream. There were few water bars constructed, which led to erosion of the skid trail. As seen in the Figure 3.7 several sections of the skid trail were constructed directly beside the stream. The haul road for this site was graveled, but there no reclamation was performed for the stream crossing. The second landing was constructed at a higher elevation, and further from the stream. This landing did not receive as much overland flow as the bottom landing did. The BMPs did not have good application or effectiveness levels, which led to a compliance level of only $54 \%$.

Intermittent streams also require a $100 \mathrm{ft}$. buffer. The required buffer and BMPs were applied to this site (Figure 3.8). A culvert was installed at the stream crossing, and the skid trail was seeded and mulched for the proper distance on both sides of the stream. Riprap was also installed at the lower end of culvert for better erosion control. The landing and haul road were constructed at a higher elevation than the stream. The landing had the proper water diversion and was also seeded and mulched. The BMPs assessed on this site ranked very well in application and effectiveness. The site was well drained with "severe" equipment limitations. These limitations could have affected the compliance if the BMPs had not been applied with as much detail. The overall BMP compliance on this tract was $84 \%$. 


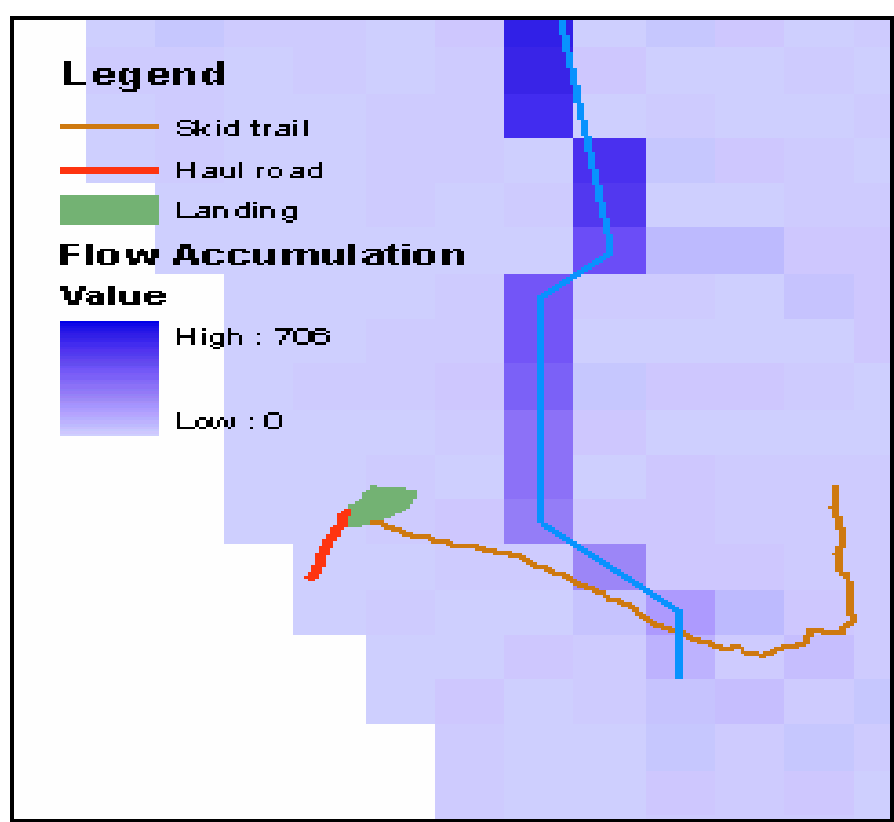

Figure 3.8. Good application of intermittent stream.

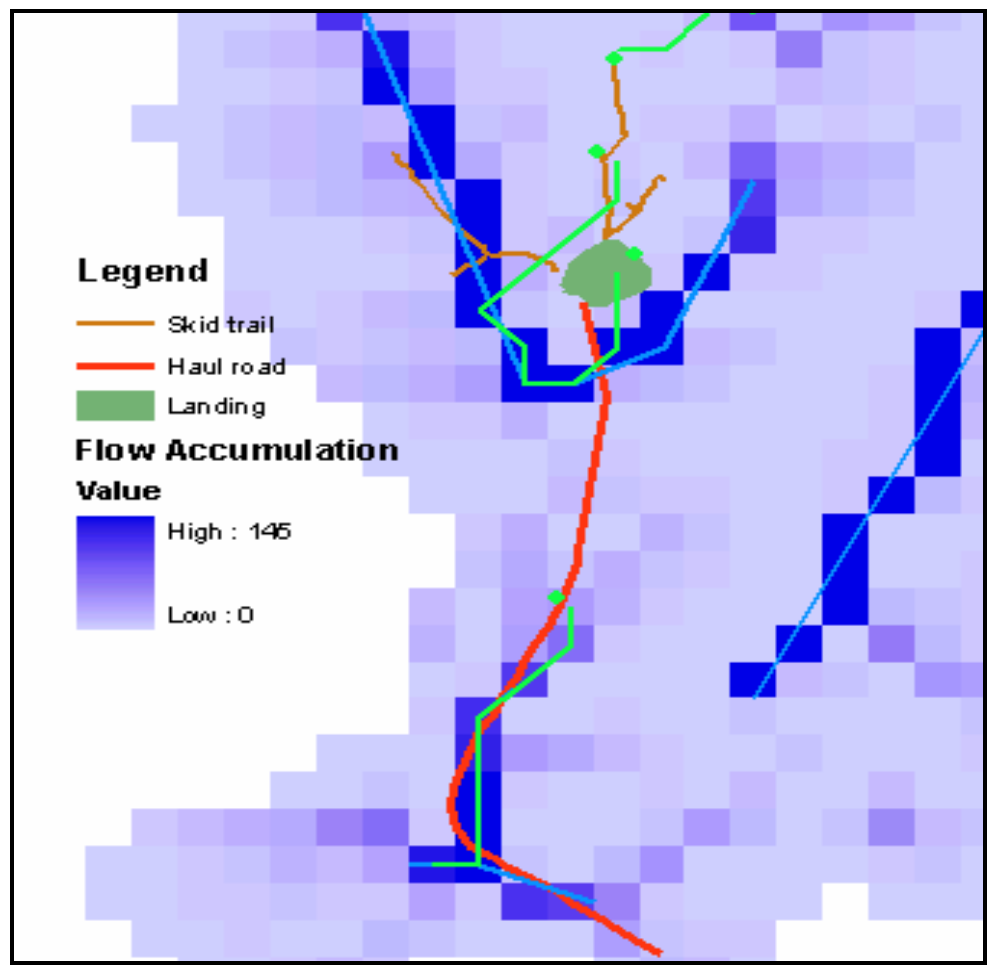

Figure 3.9. Poor application of intermittent stream.

The extended stream network was affected by the skid trail and haul road on this site (Figure 3.9). There was a "severe" equipment limitation and "moderate" erosion hazard for this 
soil. The landing was constructed at a higher elevation than the streams, which aided in drainage of the landing. This also reduced the amount of water running onto the landing. The skid trail, which crossed a major flow accumulation point did not have any reclamation performed. The stream crossing had a great deal of rutting and runoff into the stream. The haul road leading to a main road had received no gravel, and had severe rutting. Sediment was found in the stream next to the haul road. With the "severe" equipment limitations the main flow accumulation points should have been avoided if at all possible. The lack of reclamation and the SMZ violations reduced the compliance for this tract to $50 \%$.

The skid trail came into contact with the ephemeral stream on this particular site (Figure 3.10). The skid trail was reclaimed properly with an excellent ranking. The haul road and landing were constructed out of the SMZ, and at a higher elevation. This limits the runoff from the skid trail, which had the correct number of water bars, and was drained properly. The soil for this area was well drained with "severe" equipment limitations and erosion hazards. With these soil characteristics the placement of the landing was crucial. The possibility of erosion would have greatly increased had the landing been placed at a lower elevation and closer to the stream. The effectiveness of the water bars in the skid trail did not receive a perfect ranking, but they were applied often enough to reduce runoff. This tract had an overall BMP compliance of $78 \%$, which was among the highest for the sites with ephemeral streams. 


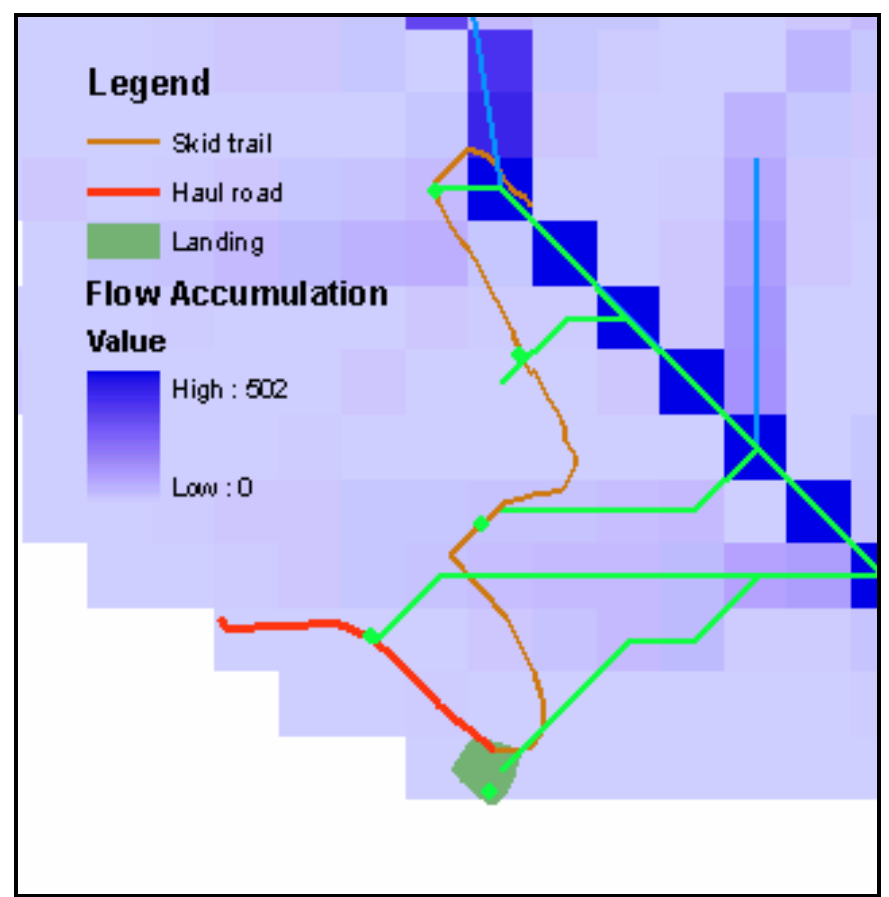

Figure 3.10. Good application of ephemeral stream.

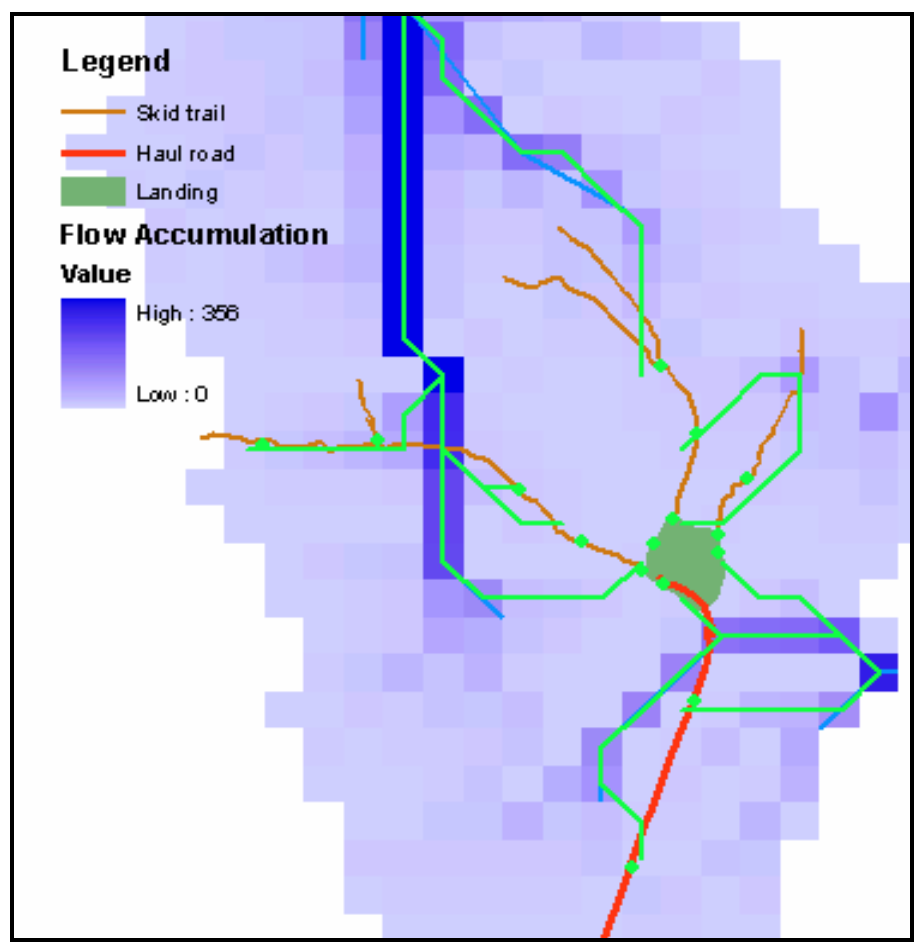

Figure 3.11. Poor application of ephemeral stream.

Two ephemeral streams were found during the time of assessment on a site where sections of the skid trail crossed these streams (Figure 3.11). During the assessment the eastern most skid 
trail crossed a low-lying area, which had water running in it toward the main stream. Soil characteristics for this site were "severe" for both erosion hazard and equipment limitation. With the lack of reclamation to the landing and skid trails, the possibility for erosion is increased. Neither of the stream crossings had been seeded or mulched, and sediment was found in one of them. Low effectiveness rankings were determined for the water bars installed. With the soil characteristics for this site and the lack of water bars, the possibility of runoff was great. A better application of water bars, seeding, and mulching would have greatly benefited this site, and increased the compliance rate. This site had numerous problems and received a compliance of only $47 \%$.

The lowest average BMP compliance was presented on the sites with perennial streams with an average compliance level of 54\% (Table 3.33). Sites with this stream type also had lower application and effectiveness levels for water bars applied, trail spacing, and stream crossings at the proper angle. These sites also had limitations due to soil type. The erosion hazard was "severe" on $37 \%$ of the sites containing perennial streams. Equipment limitations were less important with only $20 \%$ of the soils being ranked "severe". Perennial streams had the highest average rankings for application and effectiveness. Even though SMZ violations occurred, the BMPs were applied and were effective enough to reduce the risk of erosion. Landings on perennial stream sites did have the highest elevation, but still many of them were constructed inside of, or near a SMZ. These sites had the smallest average landing size, but the landings were constructed on the steepest slopes. Using the straight-line distance from ArcMap, the landings were closer to perennial streams than the other two stream types. The majority of the SMZ violations involved a skid trail, which only averaged 10 feet away from the stream. The haul roads were generally constructed away from the perennial streams. 
Landing size increased slightly on sites with intermittent streams. The average elevation decreased along with the slope on which the landings were constructed (Table 3.33). Landing distance from the SMZ increased by 16 feet for intermittent streams. Average skid trail slope was the same as for perennial streams with $9 \%$. Haul roads were closer in proximity to the intermittent streams than the other stream types. Erosion hazards increased on these sites. The rating for "moderate" erosion hazard made up $88 \%$ of the soil type. Equipment limitations increased on these soils with "moderate" making up 57\%, and "severe" being $43 \%$ of the areas. BMP application received a high ranking, but the effectiveness ranked slightly lower than on ephemeral streams. These application and effectiveness levels produced an overall compliance of $67 \%$.

Landing distance was greatest for ephemeral streams at 177 feet. Lower average elevation was found on these sites. With the elevation of the landings being lower on these sites more skid trails were constructed upslope from the landings. This again allowed for runoff from the skid trails. The average skid trail distance from the ephemeral streams was 33 feet, while haul roads were 236 feet away from this stream type. The application ranking of BMPs for these sites was $95 \%$, and effectiveness rankings were $90 \%$. These were the highest levels of application and effectiveness. However, the average compliance ranked higher than perennial streams with an average of $64 \%$, but slightly lower than intermittent streams. 
Table 3.33. Spatial analysis summary by stream type.

\begin{tabular}{lccc}
\hline & \multicolumn{3}{c}{ Stream Type } \\
\hline & Perennial & Intermittent & Ephemeral \\
\hline Landing size (acres) & 0.1 & 0.15 & 0.15 \\
Landing elevation (ft.) & 557 & 396 & 325 \\
Landing slope (\%) & 20 & 13 & 19 \\
Landing distance from SMZ (ft.) & 53 & 69 & 177 \\
Skid trail slope (\%) & 9 & 9 & 8 \\
Skid trail distance from SMZ (ft.) & 10 & 0 & 33 \\
Haul road slope (\%) & 5 & 6 & 7 \\
Haul road distance from SMZ (ft.) & 135 & 102 & 236 \\
SMZ slope (\%) & 5 & 6 & 3 \\
BMP application (\%) & 85 & 90 & 95 \\
BMP effectiveness (\%) & 79 & 87 & 90 \\
\hline & \multicolumn{3}{c}{ Erosion hazard } \\
\hline Slight (\%) & 38 & -- & 50 \\
Moderate (\%) & 25 & 88 & 50 \\
Severe (\%) & 37 & 12 & -- \\
\hline \multicolumn{3}{c}{ Equipment limitation } \\
\hline Slight (\%) & 40 & -- & 66 \\
Moderate (\%) & 40 & 57 & 34 \\
Severe (\%) & 20 & 43 & -- \\
Overall Compliance (\%) & 54 & 67 & 64 \\
\hline
\end{tabular}

The stream type distribution across the state showed that more intermittent streams were encountered in districts one and three. With the highest compliance being found on intermittent streams, this meant that these districts showed a good application of the BMPs. The perennial streams, having the lowest compliance, should be focused on more across the state. 


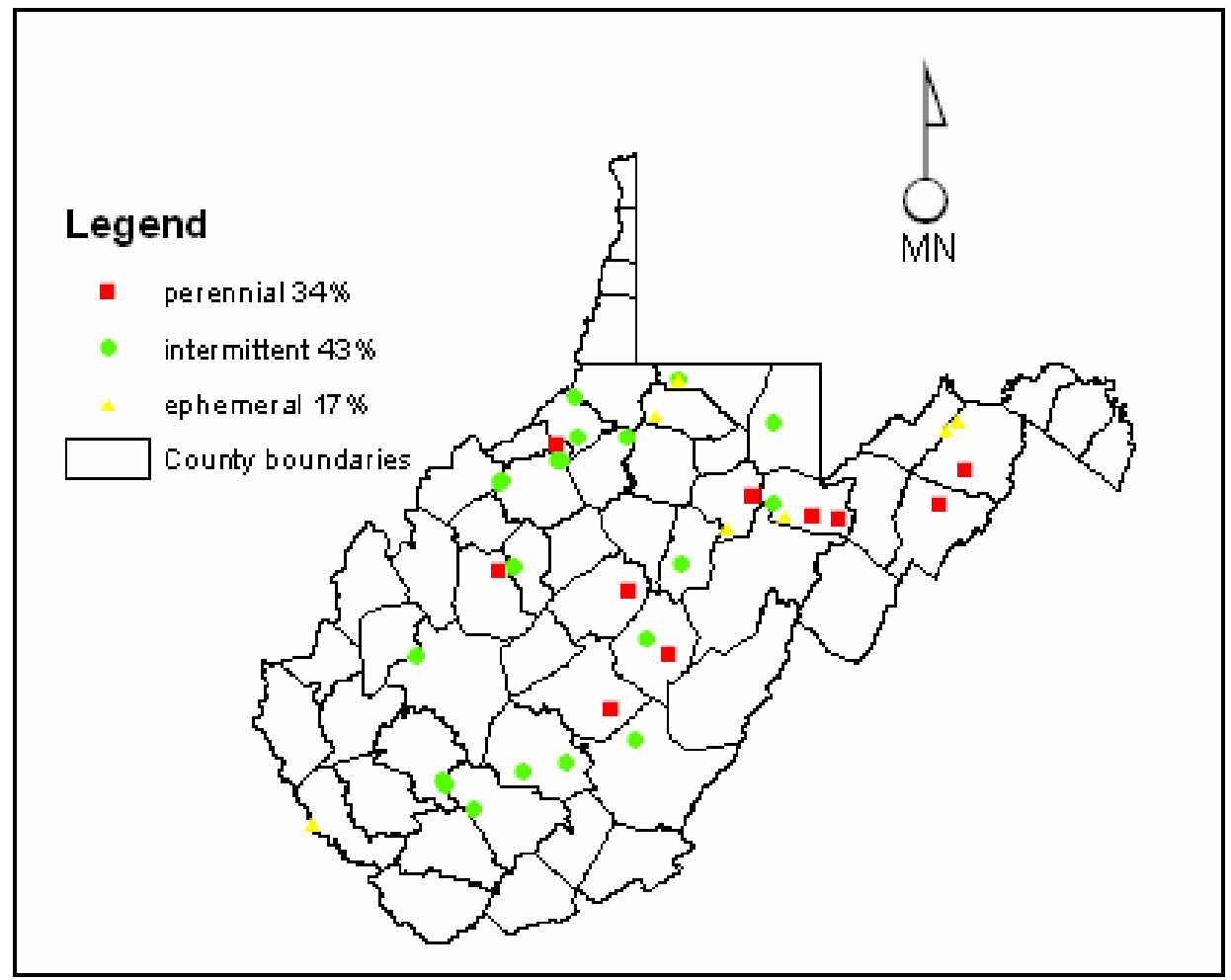

Figure 3.12. SMZ stream type by site.

\subsubsection{Distance Factors}

Leaving the correct buffer for a SMZ plays a major role in stream quality. SMZs may be entered and harvesting is allowed as long as it is minimal (WVDOF 2002). Perennial stream require a $100 \mathrm{ft}$. buffer (Figure 3.13). A temporary bridge was used for the stream crossing on this site. The use of the bridge greatly reduced any sediment that would have been caused by simply crossing the stream with the application of gravel. The soil characteristics for this site were "moderate" for both erosion hazard and equipment limitations, which could also have accelerated erosion. Water bars were applied on the skid trails and were also effective. The raindrop tool shows how the water would drain off of the skid trail, with the application of the water bars and the outsloping of the trail. The haul road and landing were constructed at a much higher elevation than the stream, and had no skid trails coming down into the landing. 


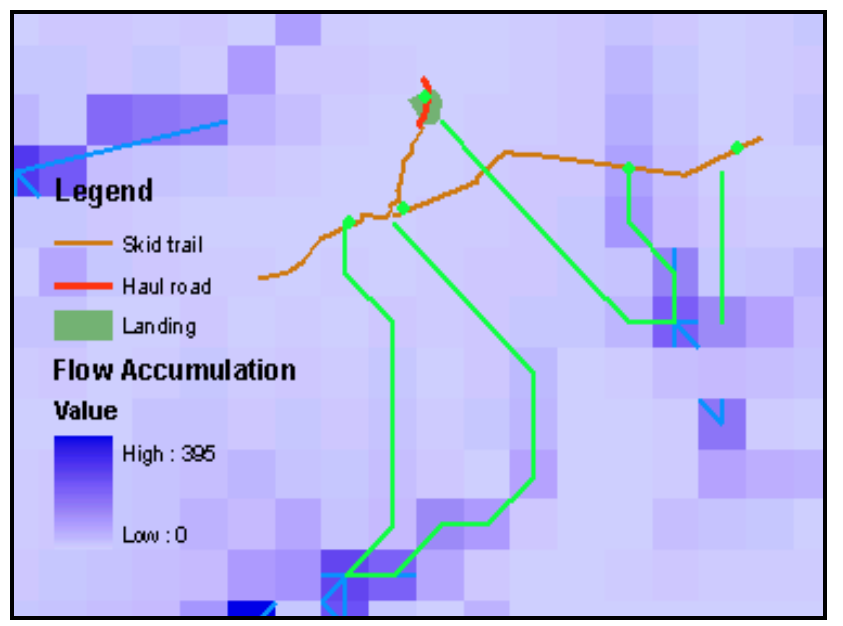

Figure 3.13. Correct SMZ width.

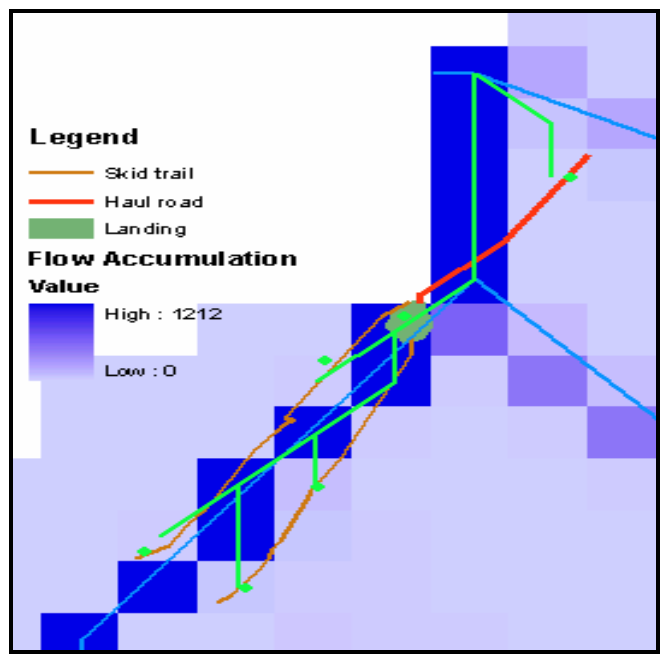

Figure 3.14. Incorrect SMZ width.

Another example showed that a perennial stream flowed directly through the site (Figure 3.14). The landing was placed beside of the stream, and the skid trail followed the stream up through the harvest. The soils on this site have "slight" erosion hazards and equipment limitations. The landing had no water diversion, and was not located on a dry site. It was not constructed at an elevation higher than the stream, nor was it seeded or mulched. There were few water bars constructed, which led to erosion of the skid trail. As seen in Figure 3.14 several sections of the skid trail were constructed directly beside the stream. There was some sediment into the stream, and ruts had formed in the skid trails. The haul road for this site was graveled, but there was no 
reclamation for the stream crossing. The BMPs were not applied effectively, which led to a BMP compliance level of only $54 \%$ for this site.

SMZ width was broken down into three classes. The widths determined from the straightline distance tool in ArcMap were used to determine the minimum distance of a feature from the SMZ. With the majority of the SMZ violations being due to skid trails there were no major differences in the distances calculated. These sites had an average landing elevation of 1,423 feet. Some of the landings received runoff from skid trails that were created upslope from the landings. This required a higher effectiveness level for water diversion from these trails. The distance of 0 to 25 feet contained the sites with the least sensitive soils. Only $27 \%$ of the sites contained soils with "severe" rankings for either soil classification. Another $40 \%$ were classified as "moderate" for both classes. The application ranking for these sites was $87 \%$, which was the lowest of the three SMZ width groups, as was the effectiveness level with only $83 \%$. These application and effectiveness levels could have a direct impact on runoff and sedimentation with these close proximities to the streams. The overall compliance for these sites was $60 \%$.

The sites that had the landings constructed between 26 and 100 feet away from streams presented a higher compliance level than the other two SMZ width groups. With the average landing elevation being 1,473 feet several of the landings were located above the streams, and had skid trails that approached from a downhill slope. This means there is less opportunity for runoff to occur directly onto the landing from skid trails. The application and effectiveness levels were higher for landings on these sites. Skid trails on these sites also showed higher levels of application and effectiveness for certain BMPs. These sites contained 50\% each of "moderate" and "severe" rankings for both erosion hazard and equipment limitations. This factor along with the short distance from the streams could affect the effectiveness of the BMPs applied. The 
application of BMPs for the shortest distance ranked much higher than the other two classes. The same is true for the effectiveness levels of these BMPs. This also led to the highest compliance level for these sites. The compliance was $66 \%$, which was $6 \%$ higher than the other two classes. This means that with proper application of the BMPs the SMZ can be reclaimed and receive a high compliance.

The last category for width included three sites in which the landings were greater than 100 feet away from the SMZ. The low elevations of the landings imply that several of the skid trails were constructed upslope from these landings. This requires a high level of application and effectiveness to reduce runoff. These sites had the same overall compliance as the first class of landings that were close to the SMZs. Erosion hazards and equipment limitations had slightly decreased ratings on these sites. Ratings were 33\% for each category. This applied to both erosion hazard and equipment limitation. The landings for these sites had high ranking application and effectiveness levels. The overall application level was 91\%, which was slightly lower than the 26 to 100 foot class. Effectiveness levels were $87 \%$, which were also second to this class. With these two rankings being only slightly higher than the 0 to 25 foot class the overall compliance remained the same at $60 \%$. One site had a low level of effectiveness for the BMPs applied to its skid trails. This was also the lowest ranking site in terms of compliance, with $51 \%$. Without this site the compliance for this category would have been $73 \%$. 
Table 3.34. Spatial analysis summary by SMZ width.

\begin{tabular}{lccc}
\hline & \multicolumn{3}{c}{ SMZ width } \\
\hline & $0-25$ & $26-100$ & $101+$ \\
\hline Landing size (acres) & 0.1 & 0.1 & 0.1 \\
Landing elevation (ft.) & 1423 & 1473 & 1260 \\
Landing slope (\%) & 18 & 12 & 12 \\
Skid trail slope (\%) & 9 & 7 & -- \\
Haul road slope (\%) & 7 & 5 & 4 \\
SMZ slope (\%) & 5 & 6 & 5 \\
BMP application (\%) & 87 & 94 & 91 \\
BMP Effectiveness (\%) & 83 & 90 & 87 \\
& \multicolumn{3}{c}{ Erosion hazard } \\
\hline Slight (\%) & 33 & -- & 33 \\
Moderate (\%) & 40 & 50 & 33 \\
Severe (\%) & 27 & 50 & 33 \\
& Equipment limitation \\
\hline Slight (\%) & 33 & -- & 33 \\
Moderate (\%) & 40 & 50 & 33 \\
Severe (\%) & 27 & 50 & 33 \\
Overall compliance (\%) & 60 & 66 & 60 \\
\hline
\end{tabular}

The required buffers appeared to be constructed more towards the central and north central part of the state (Figure 3.15). The greatest distances left from streams were found in the District 1 and District 2. This figure shows the location of the SMZs and the distance that was measured for each stream. There were no concentrated points for any one district, which means this could be a point of interest for each of the districts. 


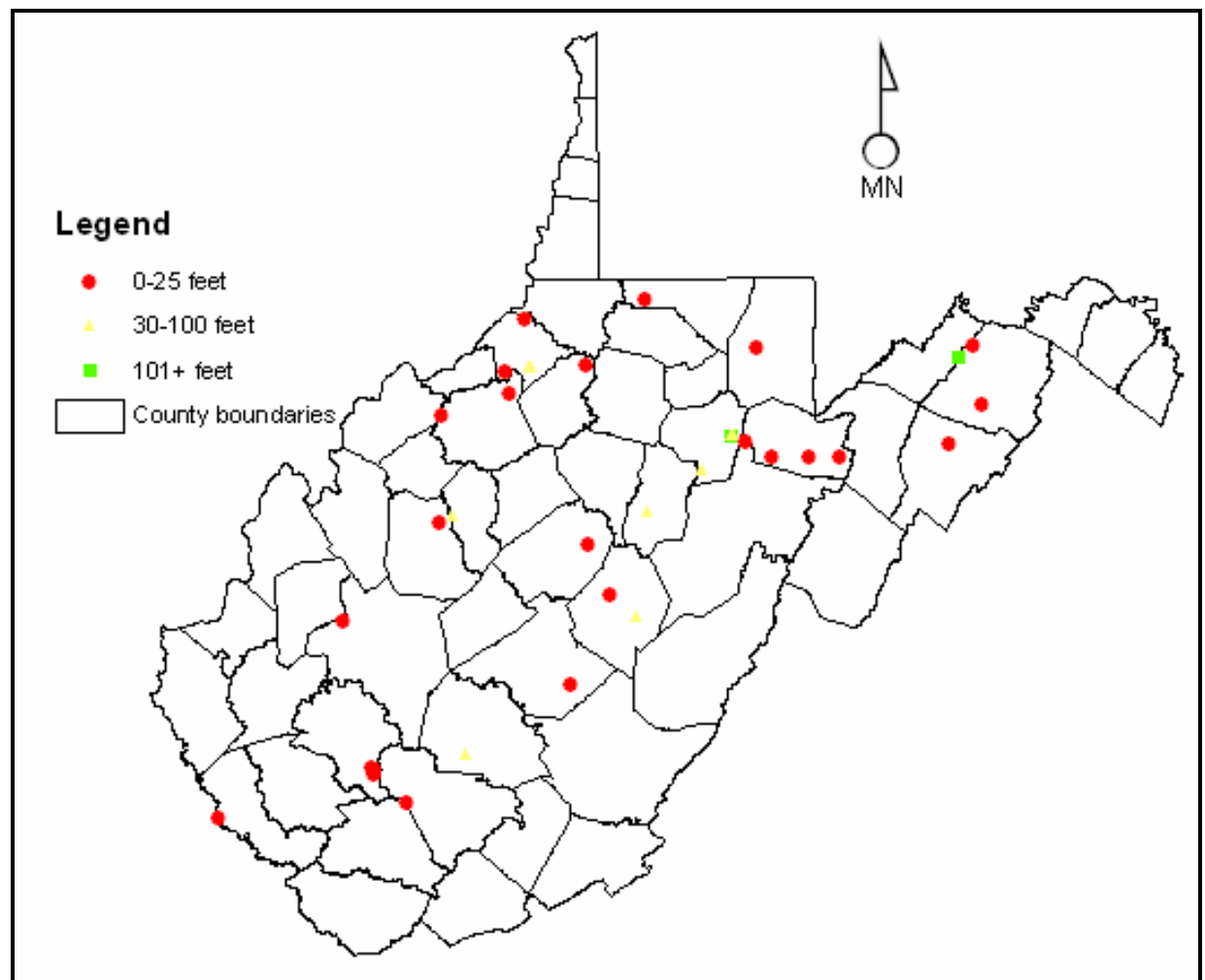

Figure 3.15. SMZ width by site using straight-line distance.

\subsubsection{Soil Type}

Soil type is a major concern while constructing landings, roads, and trails. Certain soils are more suitable for these activities, and soil information should be considered during pre-harvest planning.

Five major soil types were noticed on these sites. An example showing a site with four landings was found to have a Berks soil type (Figure 3.16). The Berks soil series tend to have lower ratings for the two soil characteristics that were focused on. This site had ratings of "slight" for both equipment limitations and erosion hazard. High levels of effectiveness were found on this site. This could be attributed to the soil type and also the buffer zone that was used. 
The Gilpin soil series had slightly higher ratings for the characteristics of erosion hazard and equipment limitation, which was found on some of the sites. The two soil characteristics in this example site (Figure 3.16) had "severe" ratings. The combination of the sensitive soil, and the activity in the SMZ resulted in the low effectiveness levels on this site. Erosion was very noticeable on the landing and skid trails. Sediment had entered the stream from both places of activity. Better application of the BMPs could have been applied on this site, but with the other factors combined their effectiveness levels may not have increased.

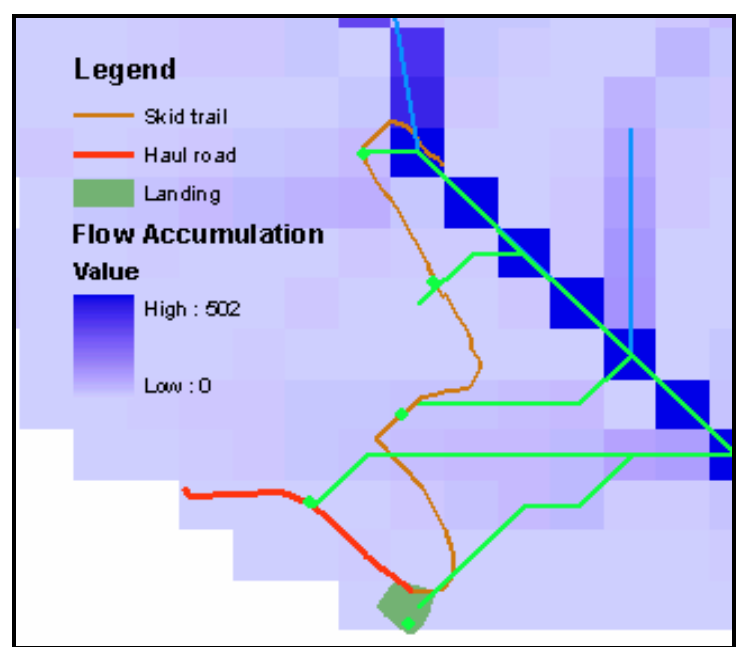

Figure 3.16. A site with Berks soil type.

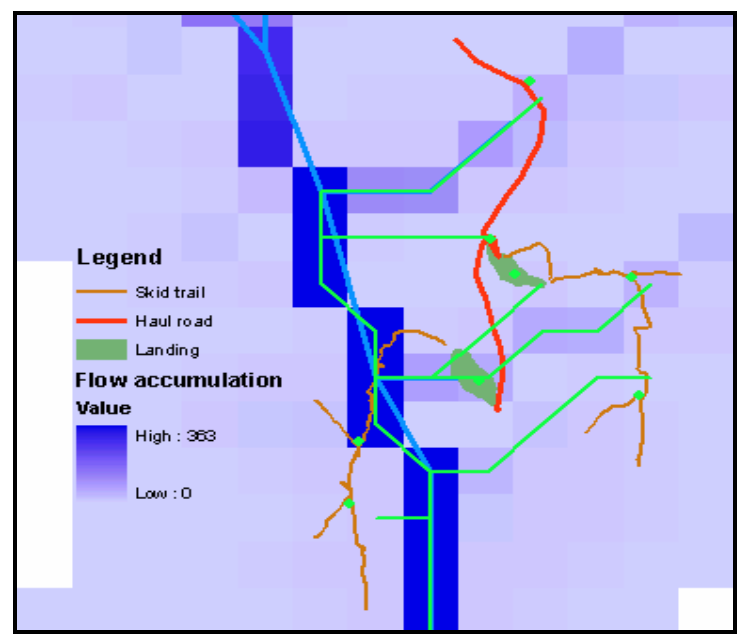

Figure 3.17. A site with Gilpin soil type. 
Landings were constructed further from the SMZ on Gilpin soils (Table 3.35). On the sites containing Moshannon and Dormont soils the landings were created inside of the SMZ for each site. With the Moshannon soils containing the largest landings constructed, this could have decreased the effectiveness of the BMPs along with the erosion hazard. The average grade of the skid trail was steepest on sites containing Moshannon soils. SMZ slope was greatest on the Dormont soil type. There were no noticeable differences in either BMP application or effectiveness levels across soil types. The application levels ranked higher on the Dormont soil series, which had "moderate" ratings for each soil characteristic. The effectiveness of the BMPs assessed ranked higher on the Dekalb series with $89 \%$. These soils had a rating of "slight", which would mean that there is less concern for erosion to begin with. Gilpin soils had an average BMP compliance of $66 \%$, which was second to the Dormont series with $70 \%$. With the amount of erosion hazards found on the Moshannon series, these sites still averaged a compliance of $63 \%$.

The raster graphic for distance measurements was overlaid onto slope and hillshade grids, which were calculated from elevation grids (Figure 3.17). The DOQQ was used to display the topography and landscape of each site. These maps allowed for each sites topography and surrounding area to be viewed. This provided a better understanding of site factors affecting the harvest and BMPs. This series of maps better illustrated the aspects of the harvest in relation to elevation, topography, and proximity of each feature. 
Table 3.35. Spatial analysis by soil type.

\begin{tabular}{|c|c|c|c|c|c|}
\hline \multirow[b]{2}{*}{ Categories } & \multicolumn{5}{|c|}{ Soil Type } \\
\hline & Gilpin & Berks & Dekalb & Moshannon & Dormont \\
\hline Landing size (acres) & 0.1 & 0.1 & 0.1 & 0.2 & 0.1 \\
\hline Landing elevation (ft.) & 1335 & 1631 & 1696 & 863 & 1161 \\
\hline Landing slope $(\%)$ & 16 & 14 & 21 & 16 & 15 \\
\hline Landing distance from SMZ (ft.) & 112 & 108 & 53 & 0 & 0 \\
\hline Skid trail slope $(\%)$ & 9 & 9 & 7 & 11 & 10 \\
\hline Skid trail distance from SMZ (ft.) & 13 & 0 & 16 & 0 & 0 \\
\hline Haul road slope $(\%)$ & 6 & 6 & 5 & 4 & 3 \\
\hline Haul road distance from SMZ (ft.) & 135 & 115 & 289 & 0 & 98 \\
\hline SMZ slope $(\%)$ & 6 & 5 & 4 & 5 & 11 \\
\hline BMP application (\%) & 86 & 87 & 89 & 84 & 90 \\
\hline \multirow[t]{2}{*}{ BMP effectiveness (\%) } & 86 & 80 & 89 & 84 & 84 \\
\hline & \multicolumn{5}{|c|}{ Erosion hazard } \\
\hline Slight (\%) & -- & 50 & 100 & 33 & -- \\
\hline Moderate $(\%)$ & 82 & 50 & -- & 33 & 100 \\
\hline \multirow[t]{2}{*}{ Severe $(\%)$} & 18 & -- & -- & 33 & -- \\
\hline & \multicolumn{5}{|c|}{ Equipment limitation } \\
\hline Slight (\%) & 50 & 50 & 100 & 100 & -- \\
\hline Moderate $(\%)$ & 50 & 25 & -- & -- & 100 \\
\hline Severe $(\%)$ & -- & 25 & -- & -- & -- \\
\hline Overall compliance $(\%)$ & 66 & 54 & 54 & 63 & 70 \\
\hline
\end{tabular}




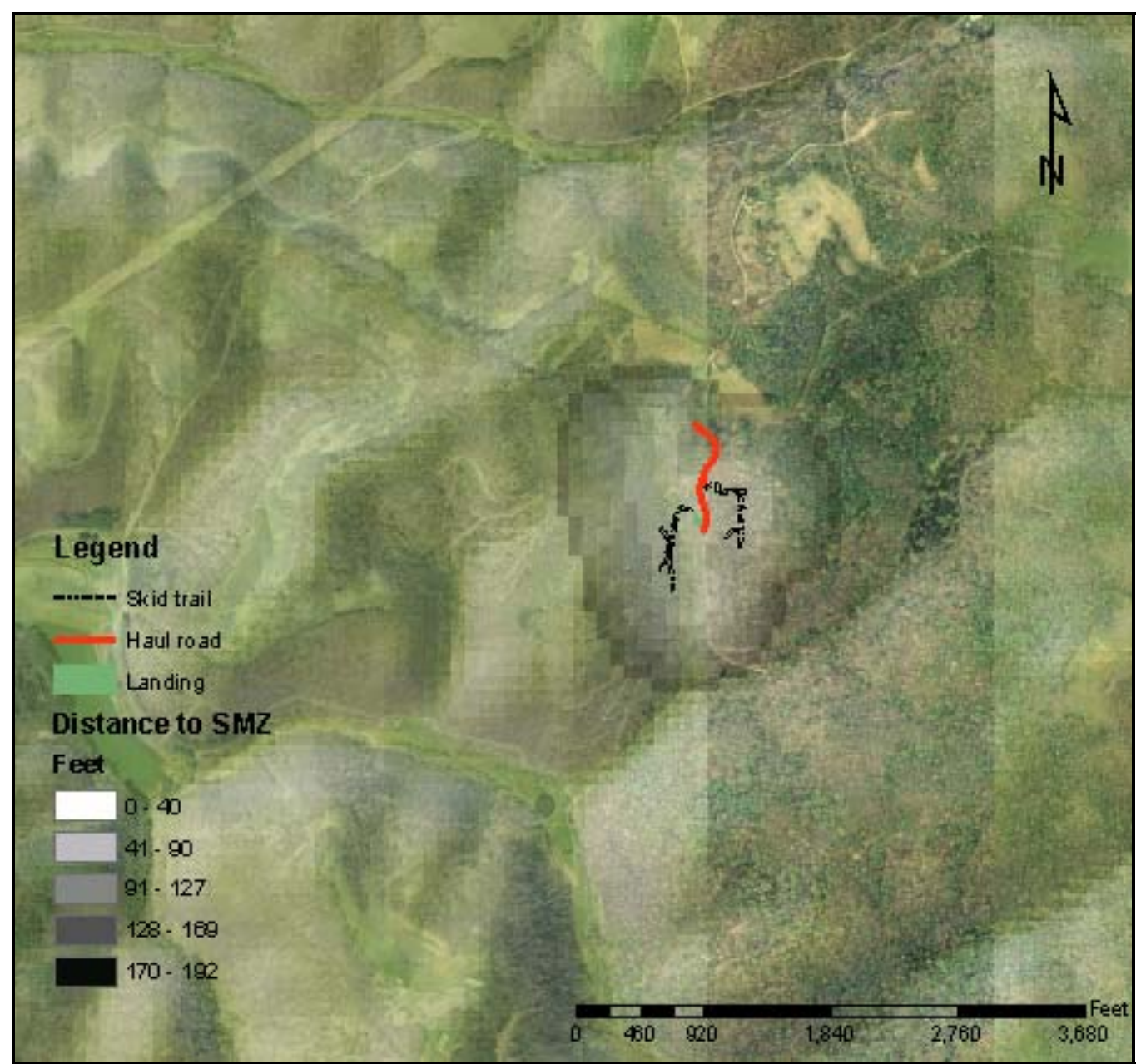

Figure 3.18. Distance raster with topography shown. 


\section{CHAPTER 4: CONCLUSIONS AND DISCUSSION}

The BMP guidelines in West Virginia have had several changes since the first assessment in 1981. Three revisions were made since the last assessment in 1996. The SMZs were a major focus in the new guidelines, such as leaving the correct width for SMZs is an increasing concern. The requirements for seeding and mulching landings were first introduced in 1996's assessment and were also examined in this study.

A general increasing trend in compliance was noted during this assessment. This study assessed the application of BMPs within the SMZ for effectiveness. This assessment found that BMPs are being applied often, and with relative effectiveness.

The number of BMPs regulating haul roads has increased since the previous assessments. Compliance also generally increased for these BMPs. There have been no major changes in the compliance of the grade of haul roads, with a compliance level of $86 \%$ in 1981 and $88 \%$ in 2005 . An increase in compliance was measured for the presence of gravel on haul roads. The compliance rate for this BMP was $92 \%$ during this assessment. Major increases for the lengths of haul road that had been seeded and mulched were noted (Table 4.1). This BMP was assessed when a haul road crossed a stream, or was constructed inside of the SMZ. More haul roads were found being constructed out of the SMZ during this assessment. The presence of cross drainages in the haul road has been a consistent area with lower compliance, which was indicated in this study. A greater number of haul road sections were seeded (82\%) and mulched (80\%) during this assessment. These compliance rates, along with an increase in haul roads constructed out of the $\mathrm{SMZ}$, indicate a greater concern to reclaim this area. 
Forester involvement and industry lands generally had higher rankings for the BMP applications. These sites were under a forester's supervision, and the knowledge of the forester was used for better application of the BMPs. There was little variation found among the six forest districts for BMP applications and effectiveness. Higher levels of application and effectiveness were presented consistently on industrial lands for all of the BMPs assessed except for the outsloping of cross drainages. The application of this BMP was $75 \%$ on private lands and $66 \%$ on industry lands. However, the effectiveness levels were $67 \%$ on private lands and $90 \%$ on the industry lands. The low application and effectiveness levels for this BMP led to a low compliance level. This could be due to the increased use of the haul roads on industry lands. These roads are specifically used often when built on a large tract.

Table 4.1. Compliances on haul roads by year (\%).

\begin{tabular}{lccccc}
\hline & \multicolumn{5}{c}{ Year of Assessment } \\
\cline { 2 - 6 } BMP & 1981 & 1987 & 1991 & 1996 & 2005 \\
\hline Grade less than & 86 & 79 & 84 & 85 & 88 \\
$\begin{array}{l}15 \% \\
\text { Culvert/bridge }\end{array}$ & -- & -- & -- & -- & 86 \\
used & & & & & \\
Presence of cross & 49 & 49 & 50 & 43 & 50 \\
drainages & 84 & 58 & 53 & 73 & 92 \\
Presence of gravel & -- & -- & -- & 37 & 82 \\
Seed applied & -- & -- & -- & 22 & 80 \\
Mulch applied & -- & -- & -- & 54 & 82 \\
Outside SMZ & & & & & \\
\hline
\end{tabular}

BMP compliance levels also generally increased on landings compared to the previous assessments (Table 4.2). The compliance for landings that were located the proper distances from streams steadily increased from $76 \%$ in 1987 to $83 \%$ in 2005 . However, the compliance level of approach roads diverted from the landing increased from $56 \%$ to $75 \%$ in 1991 , to $85 \%$ in 1996 , and then decreased to $76 \%$ in 2005 . This could be a focal point since this area receives the most 
activity during the harvest. The required distance for the SMZ was determined by stream type. The increase in compliance for this BMP shows better planning and a greater concern to avoid SMZ violations. An increase in the application of seed and mulch to the landings also showed an effort to comply with the BMP guidelines.

Higher levels of BMP application were presented on industry lands. Effectiveness levels were also high accordingly for the BMPs assessed on landings. The two fields in which industry lands had lower levels of application and effectiveness were on the number of landings seeded ( $95 \%$ vs. $88 \%$ ) and mulched ( $92 \%$ vs. $88 \%$ ). It is because that some of the industry owned lands were scheduled to be seeded the following fall. This information was extracted from the notification forms or the foresters that were contacted. The data used for the analysis was used from what was found during the time of assessment. However, higher levels of effectiveness were demonstrated on industry lands for the other BMPs measured on landings.

Table 4.2. Compliances on landings by year (\%).

\begin{tabular}{lccccc}
\hline & \multicolumn{5}{c}{ Year of Assessment } \\
\cline { 2 - 6 } BMP & 1981 & 1987 & 1991 & 1996 & 2005 \\
\hline $\begin{array}{l}\text { Out of SMZ } \\
\begin{array}{l}\text { Approach roads } \\
\text { diverted }\end{array}\end{array}$ & -- & 76 & 78 & 79 & 83 \\
$\begin{array}{l}\text { At least 25 ft. from } \\
\text { streams }\end{array}$ & 56 & 74 & 75 & 85 & 76 \\
Landing smooth & 86 & 79 & 80 & -- & -- \\
Landing drained & 75 & 82 & 82 & 86 & 81 \\
Landing seeded & -- & 85 & 82 & 86 & 78 \\
Landing mulched & -- & 39 & 34 & 70 & 73 \\
\end{tabular}

The amount of skid trail constructed on a site is always a concern. These trails can take up a large area of the harvested tract. The first sections of skid trail leaving a landing receive the most traffic throughout a harvest. This area is traveled constantly with loaded skidders and other equipment. Assessment of this area is logical due to the activity and reclamation requirements. 
With the appropriate application of BMPs this source of erosion can be greatly reduced.

Compliances rated for grade less than $20 \%$ and for water bars were generally increased from the assessment in 1981 to 2005's assessment (Table 4.3). The length of skid trail that had berm removed decreased in compliance from $60 \%$ of the 1996 survey to $40 \%$ of the 2005 assessment. This combined with the low application of water bars could increase runoff from skid trails. An increase was found in the sections of skid trail that had been seeded and mulched. These are still relatively new BMPs, which were first assessed during the 1996 study. The length of skid trail constructed inside of the SMZ increased during this assessment, in which a decrease in compliance showed that attention needs to be paid to this BMP. Application of BMPs was higher on industry lands for all BMPs measured except for trail spacing. This could be due to larger acreage harvested tracts on industry lands, or because these trails will be used in future harvests on industry lands. Private lands received higher levels of effectiveness for one BMP. The BMP for which private lands received a higher effectiveness level was trail spacing. The other BMPs assessed on skid trails had relatively higher rankings on industry lands.Private lands received an application level of $74 \%$ for the construction of water bars and a $63 \%$ level of effectiveness. The industry lands received an application level of $75 \%$ and effectiveness of $65 \%$ for the same BMP. These lower levels of application and effectiveness directly affect the compliance of the water bars on skid trails. The stream crossings received higher levels of both application (89\%) and effectiveness (89\%) for private lands. There were a greater number of SMZs encountered on private lands, which means fewer disturbances were found on industry owned lands. 
Table 4.3. Compliances on skid trails by year (\%).

\begin{tabular}{lccccc}
\hline & \multicolumn{5}{c}{ Year of Assessment } \\
\cline { 2 - 6 } BMP & 1981 & 1987 & 1991 & 1996 & 2005 \\
\hline Grade less than & & & & & \\
$20 \%$ & 69 & 75 & 72 & 77 & 79 \\
Water bars applied & 38 & 52 & 48 & 58 & 63 \\
Length smooth & -- & 73 & 61 & 78 & 88 \\
Length of berm & & & & & \\
removed & -- & 57 & 53 & 60 & 40 \\
Length outsloped & -- & -- & -- & -- & 61 \\
Seed applied & 36 & 29 & 30 & 55 & 82 \\
Mulch applied & -- & -- & -- & 19 & 75 \\
Length outside & -- & -- & -- & 87 & 76 \\
SMZ & - & & & & \\
\hline
\end{tabular}

Compliances for the correct buffer were shown in Tables 4.1 to 4.3 for ease of comparison with the 1996 study. These compliance levels dealt only with the sections of roads, or landings that were located in the designated SMZ. Whether or not the aspects of the harvest that were inside of the SMZ or were reclaimed was not addressed in previous assessments. The reclamation of these features is critical to control erosion on harvested areas. Haul roads received the proper reclamation on $72 \%$ of the sites and landings were reclaimed $75 \%$, while skid trails were reclaimed only $57 \%$ of the time. Riprap was installed on $43 \%$ of the sites to divert water. More attention needs to be given to the reclamation of the skid trails constructed inside of the SMZ. A higher application of riprap would also decrease erosion potential from water being drained off of skid trails. Since these BMPs in SMZs were first assessed in this study, there were no comparisons made to the previous assessments. Effectiveness levels of the BMPs assessed in SMZs ranked well compared to the other areas studied. Again, private lands received lower rankings than on industry lands. The application levels of the BMPs assessed were higher for the BMPs of equipment operations, landing out of the SMZ, smooth cut/fill slopes, and reclaimed haul roads. Private lands 
had a greater amount of haul road constructed inside of the SMZ, which led to a higher application $(82 \%)$ and effectiveness $(78 \%)$ level for the number of haul roads reclaimed.

Results from this assessment were compared with the previous studies specifically the results from the 1996 survey were compared with this assessment since the same assessment procedures were used for these two surveys. The overall compliance increased from $63 \%$ to $72 \%$ (Table 4.4). The increase in compliance can be attributed to the acceptance of new BMPs by loggers. During the 1996 assessment many BMPs were studied for the first time, which led to low compliance levels for some areas.

Higher compliances were found on the sites with forester involvement, or on industry owned lands. This simply means that foresters are having a positive impact on the harvests they are involved with. When private landowners hired foresters they also had a better understanding of the harvest, and were more satisfied with the operations. Forest product companies have their own foresters, and generally contract a set of loggers on their properties. These loggers may be better informed, while also being monitored by the foresters for that company. These companies have a great deal of interest vested in their property. They manage the timber as a sustainable resource, which will continue to produce wood, as well as income. Frequently private landowners see timber as a one-time income. They often cut the timber with no management consideration or future plans. Foresters can offer landowners this service. With a long-term management plan, the private landowners can use their property as a reoccurring source of income instead of trying to get as much as possible at one time. 
Table 4.4. BMP compliances in West Virginia by year of assessment.

\begin{tabular}{lccc}
\hline $\begin{array}{l}\text { Evaluation } \\
\text { Year }\end{array}$ & $\begin{array}{c}\text { Number of } \\
\text { loggers/logging sites } \\
\text { studied }\end{array}$ & $\begin{array}{c}\text { Number of } \\
\text { BMPs } \\
\text { measured }\end{array}$ & $\begin{array}{c}\text { Overall } \\
\text { compliance } \\
(\%)\end{array}$ \\
\hline 1981 & 101 & 16 & 59 \\
1987 & 106 & 26 & 71 \\
1991 & 234 & 26 & 75 \\
1996 & 95 & 20 & 63 \\
2005 & 116 & 26 & 72 \\
\hline
\end{tabular}

Questions asked of landowners were used to determine their knowledge and satisfaction about the harvest and the BMPs that were used. While only $3 \%$ of the private landowners noticed BMP violations another $9 \%$ of them reported noticing erosion. These are still high numbers considering the amount of private lands that were sampled. The number of satisfied landowners was far greater than the unsatisfied. Very few problems were reported from the landowners. Of the industrial landowners only $8 \%$ of them would not give recommendations for the loggers. These were generally loggers who had not worked for the responding companies before. The majority of the industrial landowners used contracted loggers that they work with frequently on their properties. This is a good way to develop a good relationship between the logger and industry. The logger can become more familiar with the practices that the industry expects. The high satisfaction rate for both landowner groups indicated high ratings for the loggers in West Virginia. This means that loggers have been doing a good job, and that landowners would continue to work with them or recommend them to others. The number of violations noticed and the few landowners who noticed erosion suggests that the WVDOF has been effective in inspecting the harvest operations. When the service foresters are present to give guidance to the loggers, problems can be taken care before they cause the job to be shutdown.

SMZ violations occurred least often on perennial streams although the lowest BMP compliance level was presented with this stream type. These areas can be difficult to reclaim due 
to the amount of water presented. The compliance of SMZs along intermittent streams was $67 \%$, while an overall compliance of $64 \%$ was achieved in SMZs of ephemeral streams. The sample sites for this study were logged during winter and spring months. This is a time when the majority of precipitation falls. This means that during this time most streams could have water in them. This could make it harder to avoid smaller ephemeral streams that may not have water running in them during dry periods. Sites with skid trails constructed inside of the SMZ, which had either poorly constructed or no water bars received lower compliance levels. This is also the case for landings that were not reclaimed properly and were constructed in the SMZ. This could lead to an increase in runoff and sedimentation due to the proximity to the stream.

The soil type together with the two characteristics of erosion hazard and equipment limitation demonstrated some variation in BMP compliances. Sites with the least sensitive soils had the lowest compliance levels. When the BMPs are applied, but not effective there is a greater chance for runoff and sedimentation. Sites containing more sensitive soils had higher BMP compliance levels. This reflects that the BMPs were applied and also effective on these sites. Using the spatial analysis a better understanding of compliance levels was possible. By using the maps that were created the effectiveness of the BMPs applied were better understood based on the interactions of slope, soil, and flow accumulation. When these factors were combined to be detrimental to activity the BMPs had to be applied correctly and effective to prevent runoff. When the BMPs were not applied or were not effective then a low compliance was the result.

This assessment should be helpful for aiding the WVDOF in planning the next set of revisions to the BMP guidelines. This assessment offered detailed information on areas that might need to be focused on as well as areas where loggers were doing an excellent job. It appears that more and more landings are being reclaimed properly in West Virginia. This is a main concern not 
only for erosion control, but also for the aesthetic property values. When the public sees wellreclaimed landings, haul roads, and skid trails they tend to be more accepting of the logging practice. Accordingly, the loggers and foresters create a more professional perception.

Overall BMP compliances among six Forest Districts had some variation for each set of BMPs. Higher compliance levels were presented on haul roads in Districts one $(83 \%)$ and four $(92 \%)$. It could be due to the greater percentage of sites sampled on industry owned land in District four. In District one, the explanation could be related to the number of foresters that were involved during the operations on these sites. The BMP compliance on skid trails also varied among districts from $59 \%$ in District five to $95 \%$ in District four. The higher compliance in District four could be attributed to the amount of industry land and the forester involvement. In District five, the topography and soil type make this area difficult to log, but with the proper use of BMPs this compliance level could be improved. The compliance for landings ranged from 52\% in District three to $90 \%$ in Districts four and six. The compliance in District three was significantly lower than that in the remaining districts because there was a large proportion of a private land sampled in this District. There was also a lower level of forester involvement during the harvesting operations in that district. However, District three did have the higher compliance of BMPs in SMZs with an average of $83 \%$.

Several things would be considered for future assessment and data analysis. Further spatial analysis could be performed by using precipitation data from the sample time period. This information along with analysis of the soils and stream networks for the entire sample size would allow an overview of the regions having higher BMP compliance and the reason. Examination of water quality data could also be used to determine the amount of sedimentation entering the streams at critical points. Combining this information with application and effectiveness levels of 
the BMPs could provide information on sedimentation of poorly or well reclaimed sites. The assessment of total harvest areas should also be completed. By assessing the entire harvest a complete overview of the BMPs applied can be determined. There may be areas of the harvest that were not assessed, on which, special precautions may have been taken or needed. Assessing the use and effectiveness of BMPs that are constructed further from the landing may show variation. BMPs may be lacking on areas that are more unlikely to be seen.

BMP application, effectiveness, and compliance should be examined on a regular basis for the state. By continuing to assess the BMPs the WVDOF can continue to address problems and revise the guidelines. This process along with the workshops and training classes offered to loggers could improve the application of BMPs, which should increase their effectiveness and compliance levels. By offering these classes the WVDOF has a chance to meet with loggers and address the problems and solutions to increase BMP compliance. Implementing the results from this assessment into the training classes could allow the WVDOF to better educate the loggers in West Virginia.

The use and effectiveness of BMPs are growing ever more important. A trend has been seen to assess application and effectiveness of BMPs rather than their overall compliance. These studies are being conducted in areas of storm water effectiveness also. Assessing these aspects of the BMPs across the state would allow for comparisons among other states in the region. Assessing the effectiveness of BMPs along with their application is necessary to determine the frequency of BMPs constructed on a site. This should be the focus in future assessments of BMPs in West Virginia.

With continuous assessment of the BMPs, the WVDOF could address problems that might arise. The findings from this assessment indicated that the statewide BMP compliance has been 
improved since the 1996 assessment. However, some BMPs still presented relatively low compliance levels, such as the number of cross drainages and water bars applied to haul roads and skid trails, and the length of berm removed from the skid trails. These BMPs should be stressed to the loggers throughout the education programs. The loggers would be able to know what the foresters would be expecting. Consequently, there would be a greater opportunity for the loggers to achieve a higher level of BMP compliance. The increases in seeding and mulching have shown that these practices are becoming more accepted throughout the state. By educating loggers and landowners of the importance of applying BMPs, both parties could be well informed and have better understanding of the need for BMP regulations. The results and findings from this study should be useful in developing statewide BMP training programs, locating BMP problem areas in the state, and aiding the WVDOF in maintaining reasonable BMP compliance levels. 


\section{LITERATURE CITED}

Anonymous. 1972. West Virginia forest practice standards. Charleston, WV, 52pp.

BMP Monitoring Task Force for Southern Group of State Foresters (SGSF). 2002. Silviculture Best Management Practices Implementation Monitoring: A Framework for State Forestry Agencies.

Briggs, R.D., J. Cormier, and A. Kimball. 1998. Compliance with forestry best management practices in Maine. Northern Journal of Applied Forestry. 15(2): 57-68.

Brynn, D.J. and J.C. Clausen. 1991. Post harvest assessment of Vermont's acceptable silviculture management practices and water quality impacts. Northern Journal of Applied Forestry. 8(4): 140-144.

Cullen, J.B. 2000. Best Management Practices for Erosion Control on Timber Harvesting Operations in New Hampshire. State of New Hampshire Forests and Lands. (Feb. 2000), Durham, NH.

Egan, A.F., A. Jenkins, and J. Rowe. 1996. Forest roads in West Virginia, USA: identifying issues and challenges. J. Of Forest Engineering. 8(1): 33-40.

Egan, A.F., R. Whipkey, J. Rowe. 1998. Compliance with Forestry Best Management Practices in West Virginia. Northern Journal of Applied Forestry. 15(4): 211-215.

Ellefson, Paul V.., M.A.Kilgore and M.J. Phillips. 2001. Monitoring Compliance with BMPs: The Experience of State Forestry Agencies. Journal of Forestry. 99(1):11-17.

Hewlett, J.D. 1979. Forest Water Quality: An Experiment in Harvesting and regenerating Piedmont Forest. Univ. Georgia School of For. Resour. Athens. 22 p.

Kochenderfer, J.N., P.J. Edwards, and F. Wood. 1997. Hydrologic impacts of logging an Appalachian watershed using West Virginia's best management practices. North. Journal of Applied Forestry 14(4):207-218.

Kochenderfer, J.N. and J. Hornbeck. 1999. Contrasting Timber Harvesting Operations Illustrate the Values of BMPs. $9 \mathrm{p}$.

Maine Department of Conservation. 2004. Best Management Practices for Forestry: Protecting Maine's Water Quality. MDOC (2004), Augusta, ME. 
Maine Department of Conservation. 2005. Maine Forestry Best Management Practices Use and Effectiveness. MDOC (2005), Augusta, ME.

Maryland Department of The Environment and the Maryland Forest Service. 2004. Soil Erosion and Sediment Control Guidelines for Forest Harvest Operations in Maryland. (2004), MD.

Mattson, J., J. Baumgras, C. Blinn, and M. Thompson. 2000. Harvesting options for riparian areas. In:Verry E., J. Hornbeck, and A. Dolloff (eds), Riparian Management in Forests of the Continental Eastern United States, Lewis Publishers, Washington, D.C.

New York Department of Environmental Conservation. 2004.

http://www.dec.state.ny.us./website/index.html

Ohio Division of Forestry. 1999. Evaluation of Logging Best Management Practices on Private Forest Lands in Ohio. August 1999.

Paff, W. 1981. Tabulation of the use of best management practices by loggers. West Virginia Division of Forestry. Charleston, WV.

Patric, J.H. 1977. Soil erosion and its control in eastern woodlands. North. Log. Timber Proc. $5: 4$.

Pennsylvania Department of Environmental Protection Bureau of Watershed Management. 2003. Controlling Erosion and Sediment from Timber Harvesting Operations. (April 2003), Harrisburg, PA.

Phillips, M., L. Swift Jr., and C. Blinn. 2000. Best management practices for riparian areas. In: Verry E., J. Hornbeck, and A. Dolloff (eds), Riparian Management in Forests of the Continental Eastern United States, Lewis Publishers, Washington, D.C.

Reinhart, K.G., A.R. Eschner, and G.R. Trimble, Jr. 1963. Effect on streamflow of four forest practices in the mountains of West Virginia. USDA For. Serv. Res. Pap. NE-1. 79 p.

Rothwell, C.L. 1983. Erosion and sediment control at road-stream crossings. For. Chron. 59(2):6266.

Ryder, Roger and Post, Tim. COFE Proceedings. Abstract and Presentation CD. A Repeatable BMP Monitoring Methodology. Bar Harbor, Maine. Sept. 2003.

Schuler, J.L. and R.D. Briggs. 2000. Assessing application and effectiveness of forestry best management practices in New York. Northern Journal of Applied Forestry. 17(4): 125-134.

Sherman, R. 1985. WV forestry volunteers for clean water. West Virginia Tree Farm News. No. 9. 
Tebo, L.B. 1955. Effects of siltation, resulting from improper logging, on the bottom fauna of a small trout stream in the southern Appalachians. Progr. Fish-Cult. (April). P. 64-70.

Wang, J., J. McNeel, S. Milauskas. 2004. Logging Sediment Act and Forestry Best Management Practices in West Virginia: A Review. Northern Journal of Applied Forestry. 21(2): 93-99.

West Virginia Division of Forestry. 1986. Forestry and water quality in West Virginia. Report VIII-Silviculture 208 Program, Charleston, WV.

West Virginia Division of Forestry. 1997. Best Management Practices for Controlling Soil Erosion and Sedimentation from Logging Operations in West Virginia. WVDOF-TR-96-3 (March 1997), Charleston, WV.

West Virginia Division of Forestry. 2001. Best Management Practices for Controlling Soil Erosion and Sedimentation from Logging Operations in West Virginia. WVDOF-TR-96-3 (June 2001), Charleston, WV.

West Virginia Division of Forestry. 2002. Best Management Practices for Controlling Soil Erosion and Sedimentation from Logging Operations in West Virginia. WVDOF-TR-96-3 (August 2002), Charleston, WV.

West Virginia GIS Technical Center. 2005. http://wvgis.wvu.edu/.

Whipkey, R.D. and R.P. Glover. 1987. Report on use of best management practices on logging operations in West Virginia Div. Of For., Charleston, WV.

Whipkey, R.D. 1991. An evaluation of the use and effectiveness of best management practices to control nonpoint sediment from logging operations in West Virginia. West Virginia Div. Of For. Pub. WVDOF 91-3, Charleston, WV.

Yonce, M. and R. Visser. 2004. Evaluation of Methods and Procedures for Best Management Practices Monitoring and Reporting in the Southeast United States. Virginia Tech Department of Forestry. 2004. 


\section{APPENDIX A: SAMPLE SITE PICTURES}

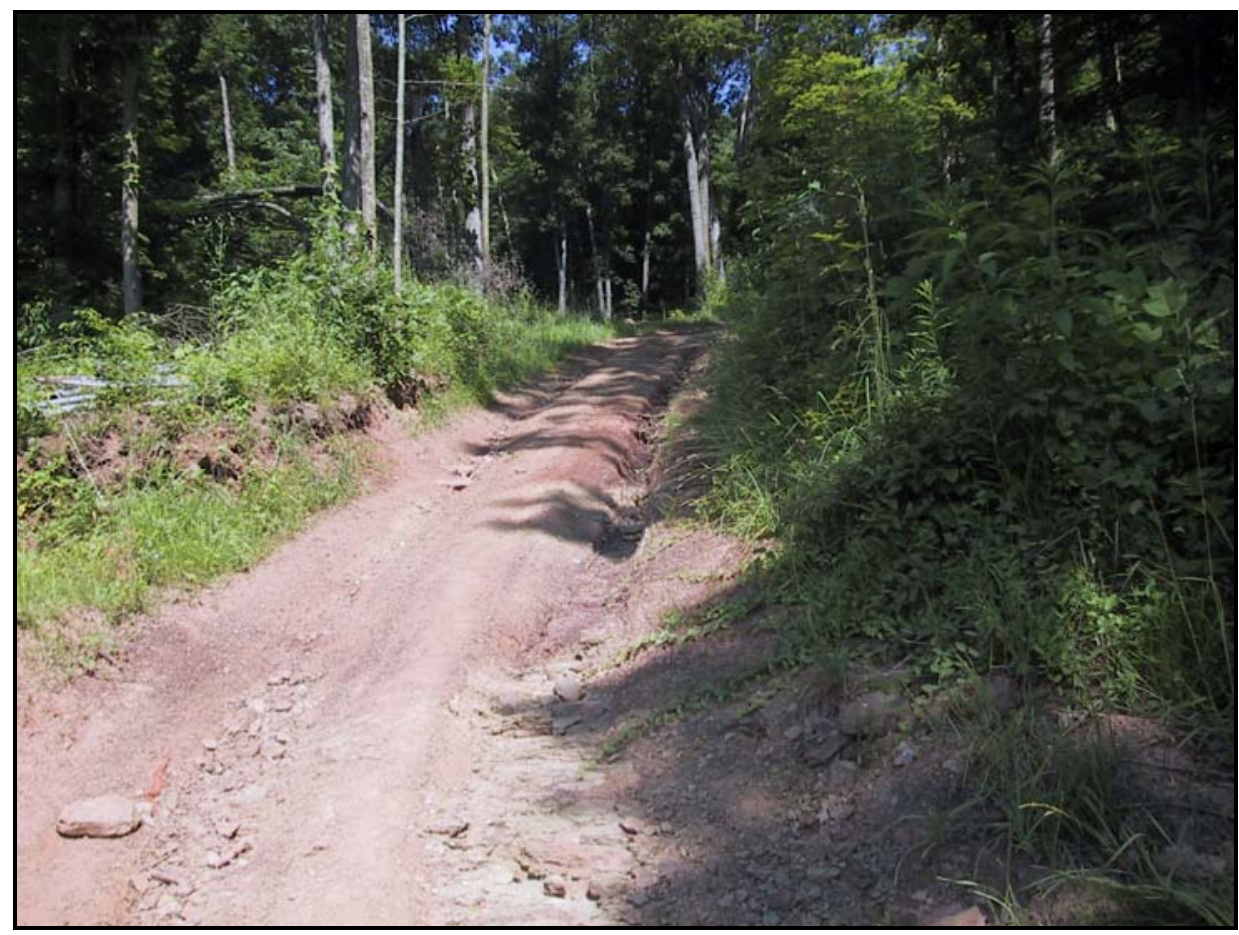

Figure A.1. Poor application of waterbars on a skid trail.

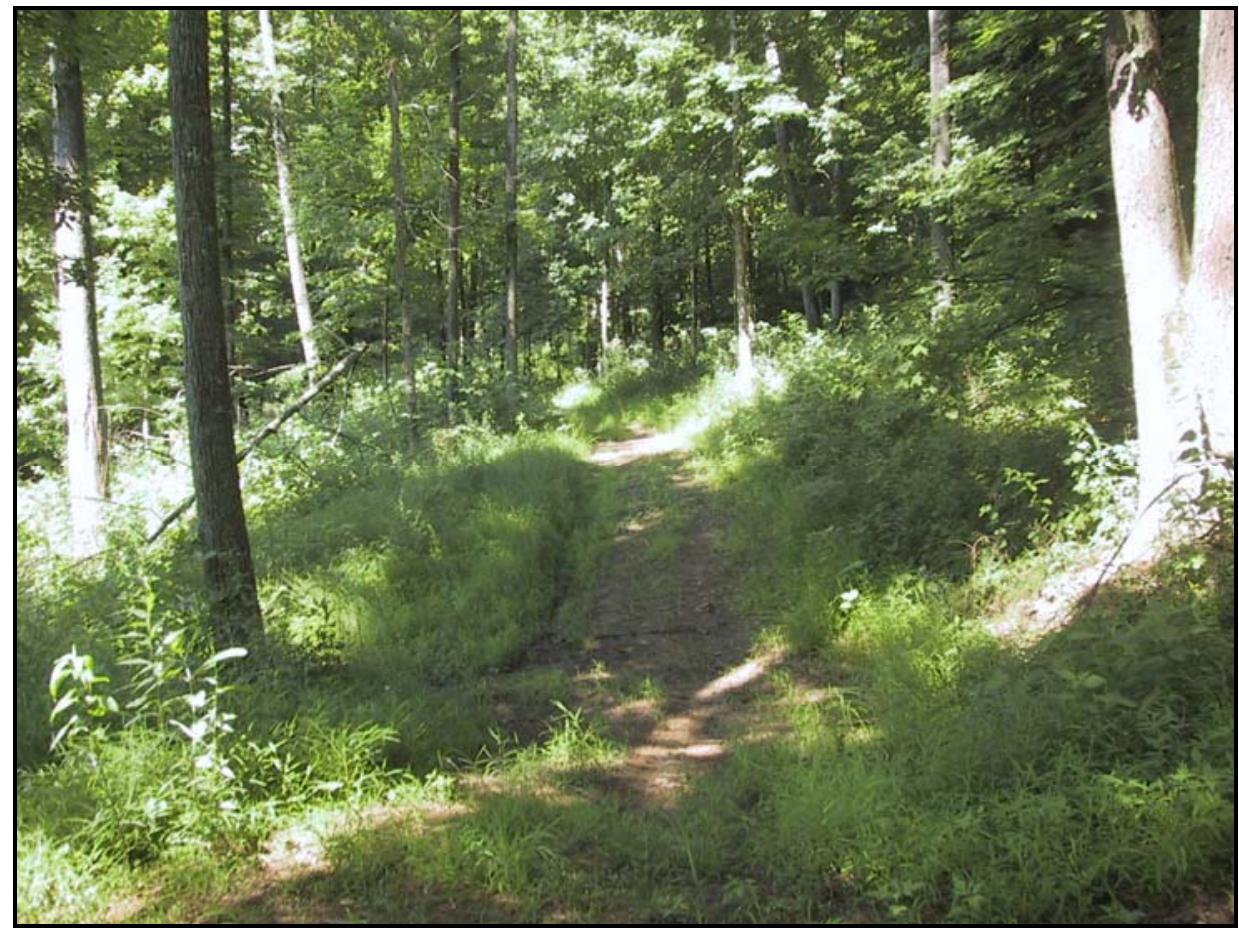

Figure A.2. Good application of outsloping on a skid trail. 


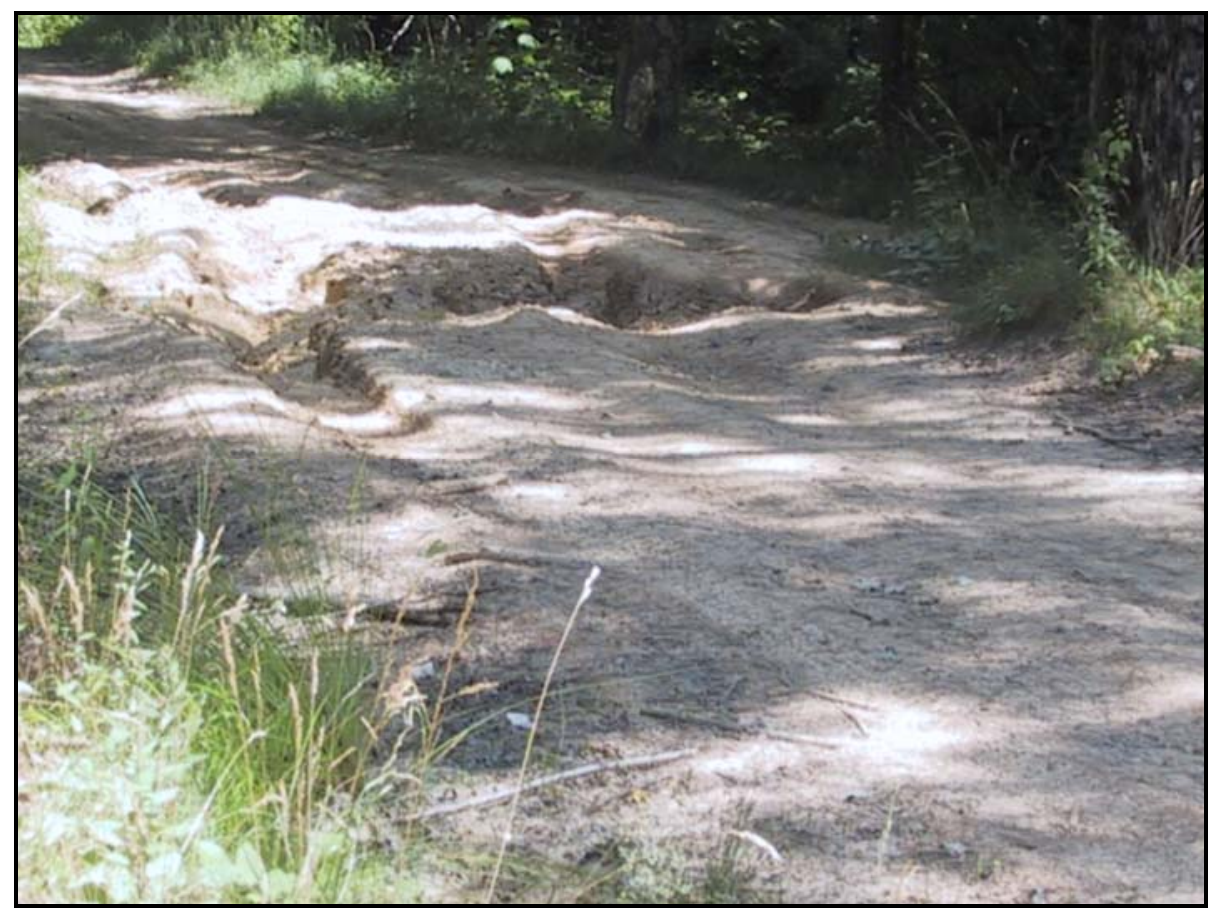

Figure A.3. Poor application of cross drainage in a haul road.

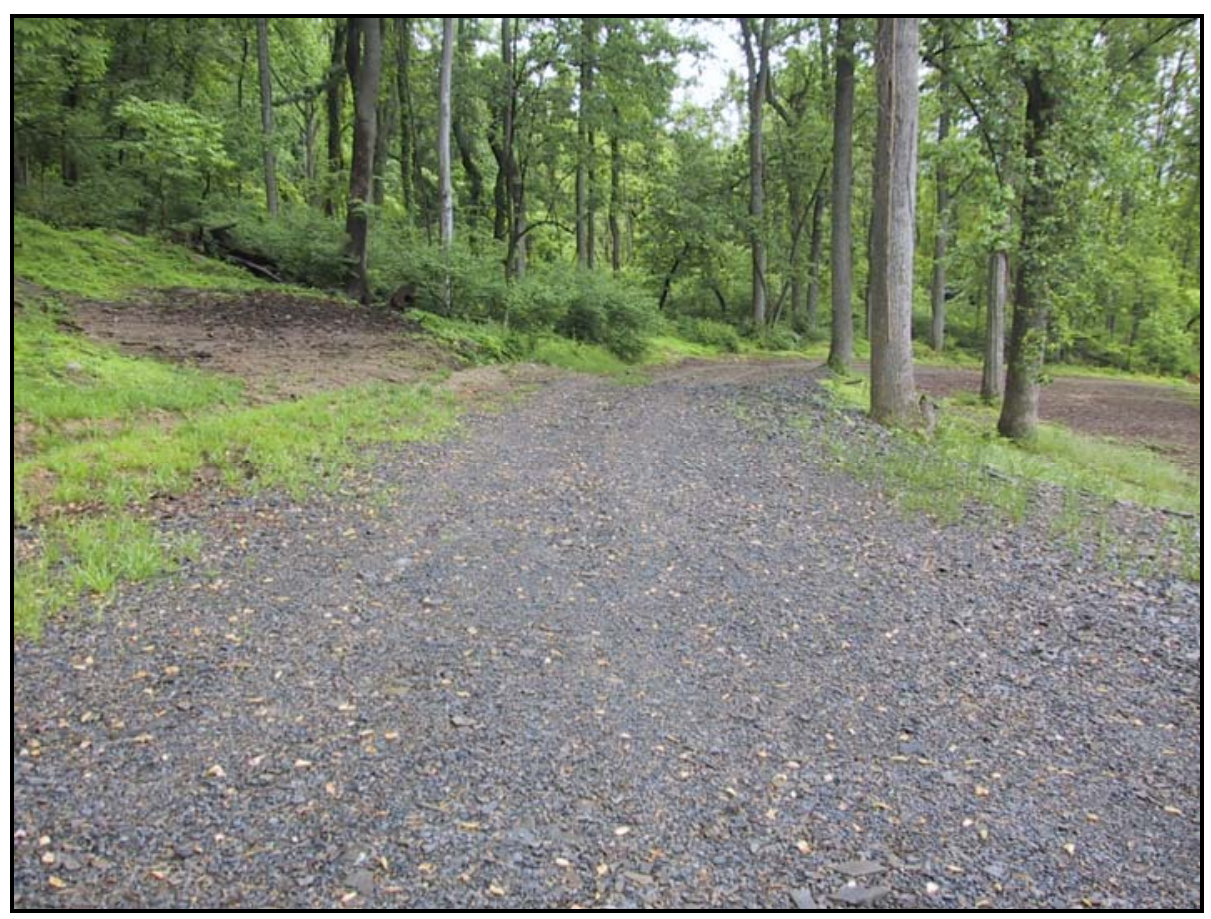

Figure A.4. Good application of gravel applied to a haul road. 


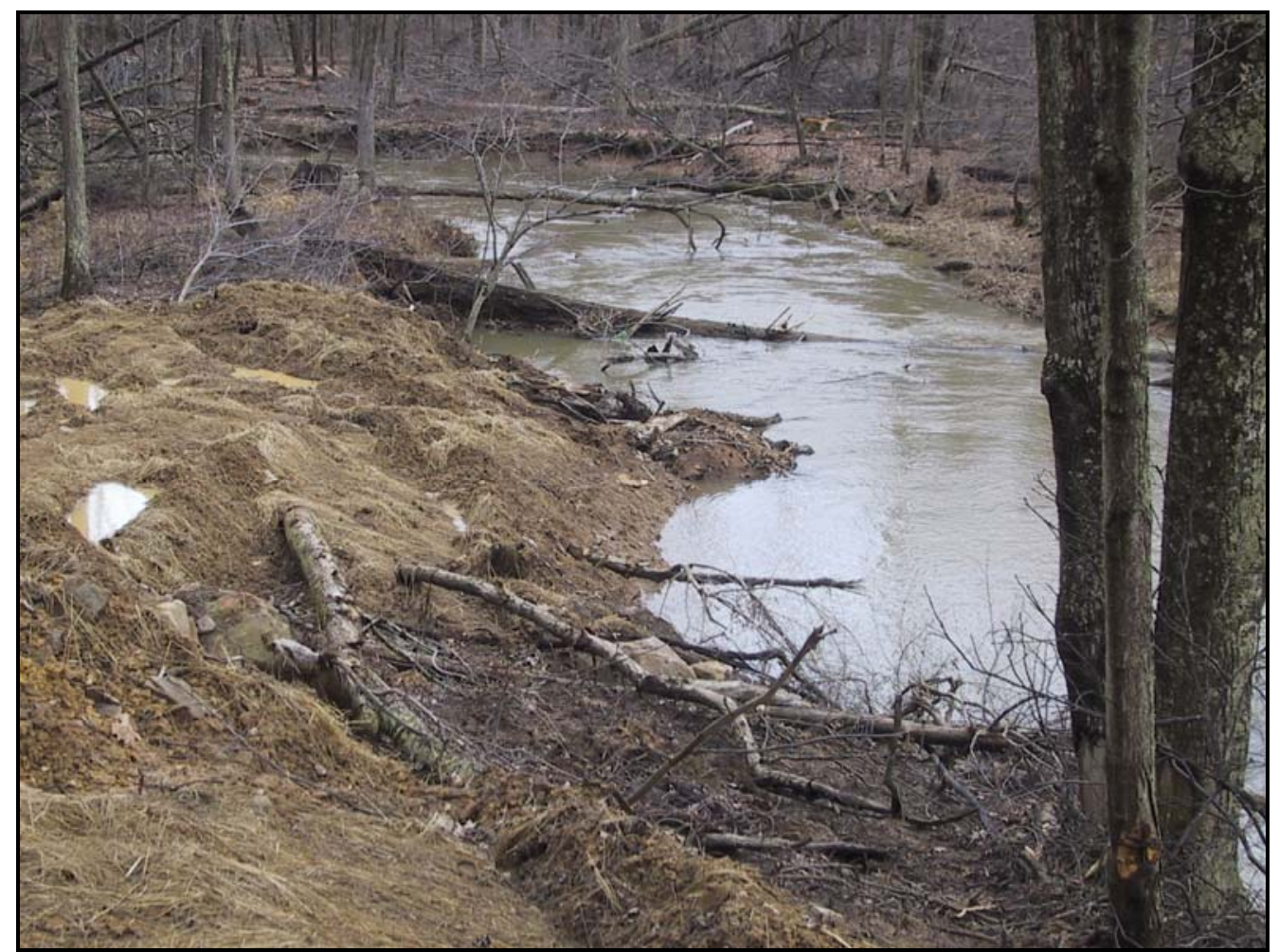

Figure A. 5. Poor application, effectiveness, and compliance of reclamation in a SMZ.

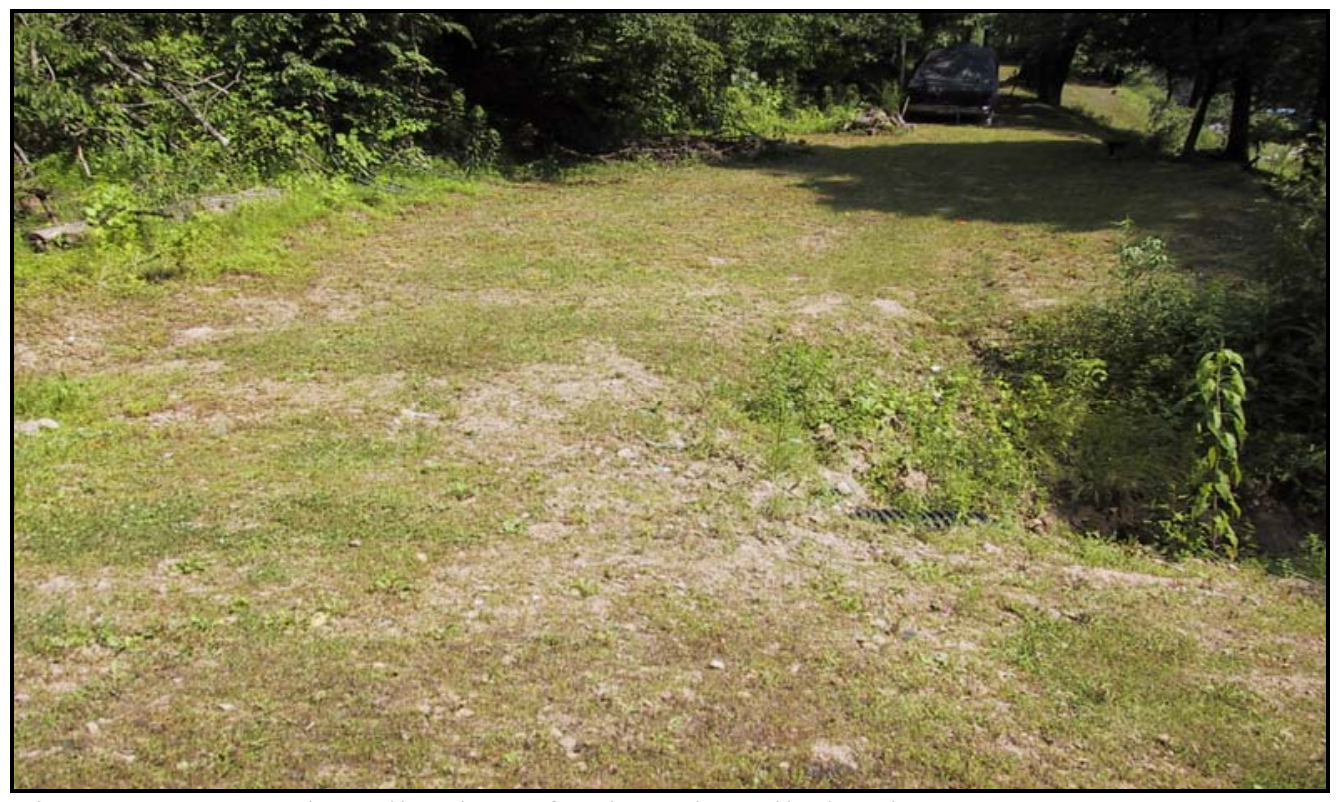

Figure A.6. Good application of culvert installation in a SMZ. 


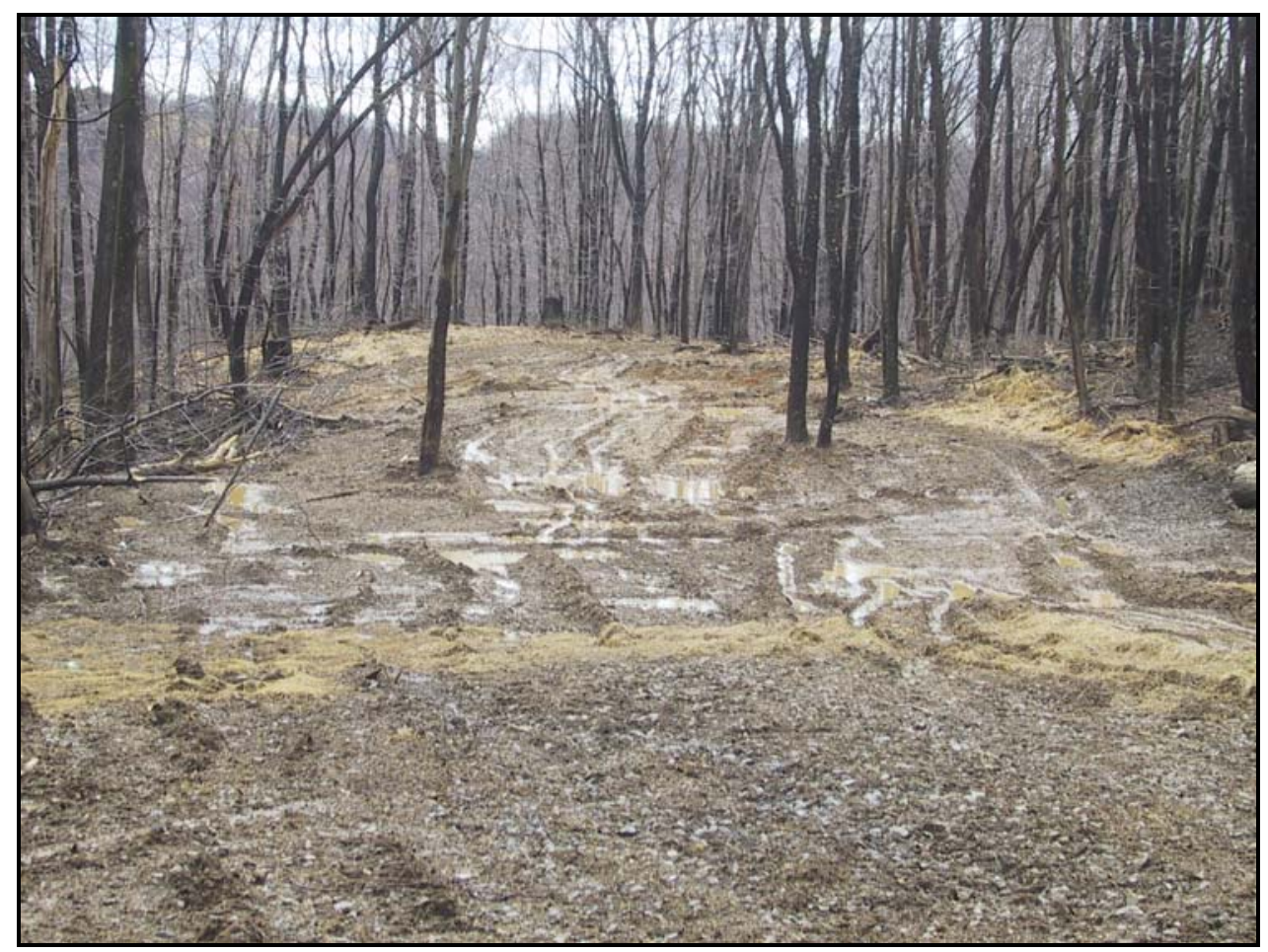

Figure A.7. Poor application and compliance of drainage on a landing.

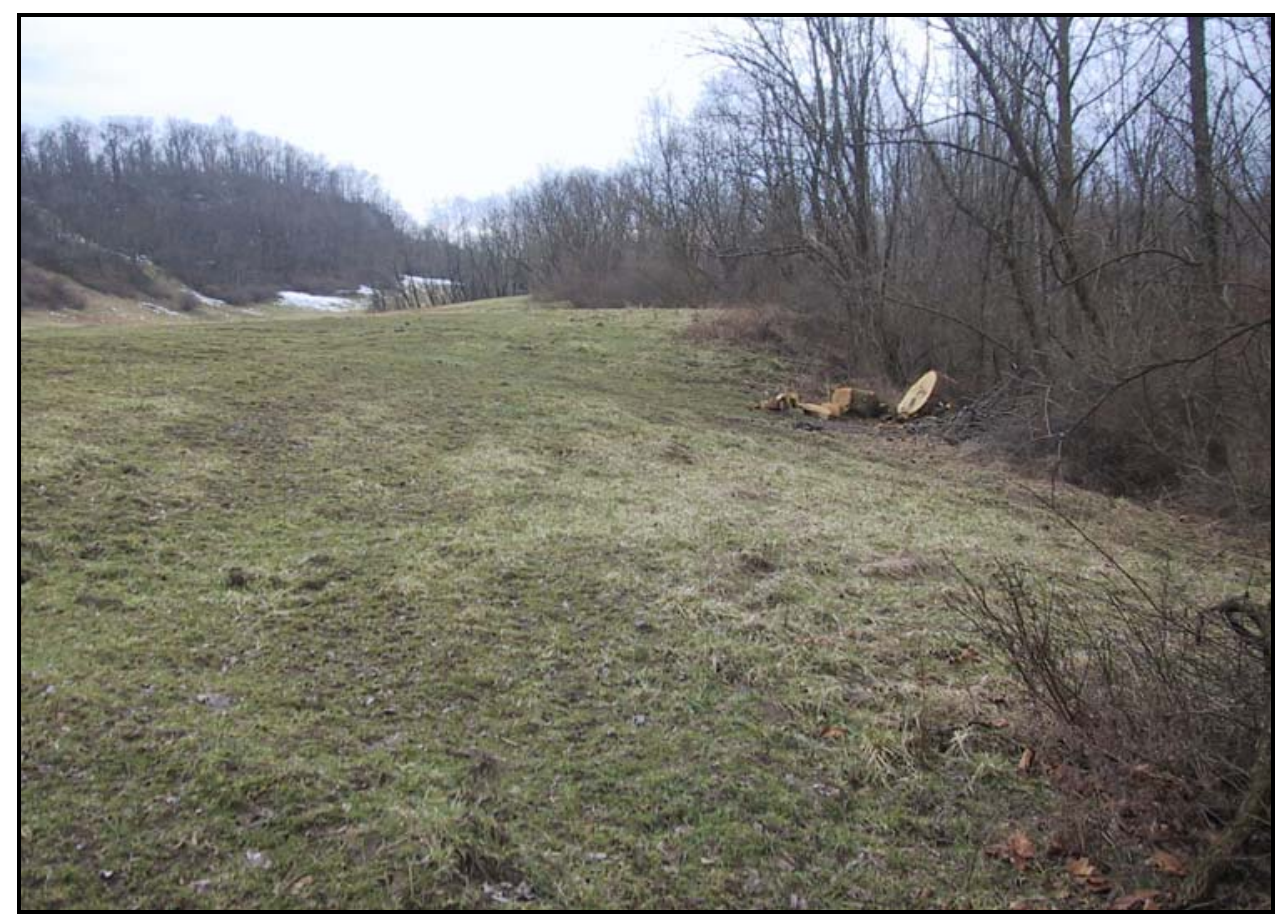

Figure A.8. Good application and compliance of reclamation on a landing. 